\title{
Construindo imagens, fazendo clichês: fotógrafos pela cidade'
}

\section{Eliana Almeida de Souza Rezende ${ }^{2}$}

RESUMO: O trabalho aqui desenvolvido parte da análise de duas coleções de fotografias, uma paulistana e outra lisboeta, produzidas nas duas primeiras décadas do século XX, que se articulam através de suas semelhanças temáticas. A pesquisa apresentada não pretende ser nem a somatória das diferentes imagens nem a segmentação das mesmas por agência produtora, mas, antes de tudo, ser um discurso sobre a cidade, onde cada imagem dialoga com as demais produzidas sobre o mesmo tema. $\bigcirc$ eixo de construção deste diálogo entre as diferentes imagens está no discurso sanitário e pretende contribuir com um dos muitos olhares possíveis sobre a cidade.

PALAVRAS-CHAVE: Urbanização. Trabalho informal. Fotografia. Higiene. São Paulo. Lisboa.

ABSTRACT: This paper is based on the analysis of two photographic collections taken as documentary assemblages and marked by a crisscross of intertwined themes. The research presented here is not intended as a sum of the different images or a segmentation of such images by producer; in fact, it is meant to be a discourse about the city, where every image dialogs with every other picture about the same theme. The dialog between the various images revolves around the topic of sanitation, and it is intended as a contribution to our understanding of the theme from one perspective, among so many other possible ways of looking at the city. KEYWORDS: City. Urbanization. Photography. Hygiene. São Paulo. Lisbon.

Pensado em sua forma estendida e tentacular, o espaço urbano revelase como sendo o centro de diferentes preocupações e instâncias políticas, econômicas e sociais. Campo de forças onde se colocam as relações sociais, nas suas diferentes formas: resistências, lutas, tensões, assim como em suas solidariedades, anseios e projetos. $\bigcirc$ viver urbano desenha-se, desta forma, como uma tessitura de diferentes interesses.

\begin{abstract}
1. Este artigo teve como base a tese de doutorado apresentada ao IFCH-Unicamp, intitulada: Imagens de cidade: clichês em foco... (São Paulo e Lisboa, 1900-1928), sob a orientação da Prof ${ }^{a}$. Dr ㄹ. Maria Stella Martins Bresciani.

2. Programa de Pós-graduação do IFCH-Unicamp. Historiadora, arquivista, conservadora e restauradora de fotografias. E-mail: <eli_rezen de@yahoo.com.br>
\end{abstract}


3.As correspondências cordialmente me foram cedidas por Cristina de Campos, que desenvolveu dissertação de mestrado - intitulada A cidade através da Higiene, 1925-1945: as propostas de Geraldo Horácio de Paula Souza para São Paulo -, defendida em março de 2001, sobre a atuação desse médico sanitarista, sendo que várias foram incorporadas, no decorrer do $1^{\circ}$ semestre de 2000, em seu Trabalho do Programa de Pós-graduação em Estruturas Ambientais Urbanas da FAU-USP: $A$ formação médica e bigienista de Geraldo de Paula Souza. Brasil e Estados Unidos. 1908 a 1920.
Não são visíveis, nem são facilmente detectados os limites, os muros da exclusão. Diferentes das cidades medievais, com seus muros altos e bem marcados impondo e determinando limites e territórios de marginalidade, de fronteiras - áreas de comércio e trocas materiais, simbólicas, sagradas e profanas -, as cidades analisadas conhecem a indefinição de tais limites. Outros são os critérios para a exclusão, a marginalidade, o informalismo do trabalho e as redes de solidariedade e lutas sociais.

Ritmo e movimento pulsam de suas ruas e dos seus habitantes. A experiência da urbanidade é viva, veloz, carregada de relações e conexões. Com sons e tons vindos da sua circulação. Circulação de riquezas, pessoas, vida.

trabalho aqui desenvolvido parte da análise de duas coleções de fotografias consideradas como conjuntos documentais que estão ligados por temáticas que se interpenetram, e que poderiam ser assim caracterizados:

- $\bigcirc$ primeiro conjunto de imagens se refere à produção amadora do Dr. Geraldo Horácio de Paula Souza, médico sanitarista, que atuou na área de saúde nos primeiros anos do século XX, na cidade de São Paulo. A coleção compõe-se de 153 imagens produzidas entre as décadas de 1910 e 1920, arquivadas na Biblioteca de Arquitetura e Urbanismo da Universidade de São Paulo.

Geraldo Horácio de Paula Souza teve sua formação na Faculdade de Medicina no Rio de Janeiro, graduando-se em 1913. Academicamente, o ano de 1914 vê seu ingresso como assistente da cadeira de Química, da recémcriada Faculdade de Medicina e Cirurgia de São Paulo, e já em 1917 está com as funções de professor-substituto de Higiene. Parece ser exatamente deste período o interesse de Paula Souza pela fotografia. De acordo com correspondências ${ }^{3}$ enviadas à mãe quando estudava nos Estados Unidos, sua primeira câmara, uma Kodak, foi adquirida em janeiro de 1919. Ele a descrevia como sendo "[...] uma pequena máquina fotográfica que cabe no bolso [...]", conforme carta escrita em 25.1.1919. Já em carta datada de 16.3.1919, Paula Souza escreve sobre a experiência de ser fotógrafo: "[...] aqui é muito fácil ser fotógrafo. Compra-se uma máquina. Aprende-se a apertar o botão da objetiva, manda-se o rolo de filmes para a farmácia e recebe-se a foto revelada e copiada em papel dois ou três dias depois [... $]^{\prime \prime}$.

Com fins de identificação e/ou documentação, a utilização da fotografia pela medicina e pela justiça foi uma constante desde a sua invenção e conseguiu ampla divulgação no decorrer dos séculos XIX e XX. $\bigcirc$ caráter documental e comprobatório era tomado como prova de realidade e acompanhava a rotina de trabalho de diferentes profissionais, em nosso caso específico, os ligados à saúde. Utilizada desta forma, a fotografia servia aos interesses da medicina como instrumento de dissecação do tecido social, fragmentando e oferecendo ao olhar especialista elementos para análise com um referencial vindo do século XIX, ou seja, a imagem como possuidora de um estatuto de veracidade e, portanto, podendo ser utilizada como prova. 
- O segundo conjunto documental foi localizado no Arquivo Fotográfico da Câmara Municipal de Lisboa ${ }^{4}$. Dos fotógrafos analisados, foi escolhido Joshua Benoliel, pela qualidade de suas imagens, consideradas como representativas de uma determinada forma de olhar sobre a cidade. Mereceriam ser trabalhadas não apenas por sua beleza e qualidade técnica, facilmente verificáveis, mas também pelo tratamento diferenciado dado aos temas que envolviam a cidade, como, por exemplo, os trabalhadores urbanos, as multidões, as greves, aspectos relacionados à higiene e à saúde etc. Sua produção estava concentrada entre os anos de 1906 e 1918, quando fornecia inúmeros clichês para a llustração Portugueza e para o jornal O Século.

Da sua vasta obra - cerca de 60 mil clichês - boa parte foi pulverizada em diferentes acervos, devido à venda desses clichês por seu filho. A maior parte está localizada no arquivo do jornal $O$ Século e é composta por um universo de cerca de 11 mil imagens, custodiado pelo Arquivo de Fotografia de Lisboa, do Centro Português de Fotografia, provisoriamente instalado na Torre do Tombo. Cerca de 3 mil clichês foram incorporados ao Arquivo Fotográfico da Câmara Municipal de Lisboa - mais precisamente 3036 - e outra parte, bastante menor, dispersou-se entre a Guarda Nacional Republicana, o Automóvel Clube de Portugal, a antiga A Brasileira ${ }^{5}$ e o Museu Histórico-Bibliográfico da Assembléia Nacional. Por uma questão de acessibilidade ${ }^{6}$ e de representatividade, tomouse como universo de pesquisa os conjuntos documentais sob custódia do Arquivo Fotográfico da Câmara Municipal de Lisboa, os do Arquivo de Fotografia de Lisboa (do Centro Português de Fotografia) e as imagens estampadas na revista Ilustração Portugueza. Deste modo, desconsiderando as repetidas ou muito similares e buscando tomar clichês com diferentes temáticas, chegou-se ao número de duzentas imagens: 75 digitalizadas e as demais publicadas na Ilustração Portugueza.

Tal recorte metodológico só foi possível a partir de farta investigação nas publicações dos clichês nos diferentes números da llustração Portugueza e nas reportagens do jornal $O$ Século, onde se pôde determinar, com uma margem bastante segura, as pautas jornalísticas que justificavam a produção imagética desse fotógrafo?.

Diferente de outros fotógrafos seus contemporâneos, Benoliel nunca se estabeleceu em um estúdio. Era um repórter fotográfico e assim viveu por toda a sua vida. Dedicou toda sua energia e capacidade de trabalho a fornecer clichês à imprensa alfacinha ${ }^{8}$. Introduz na imprensa portuguesa uma forma diferente de fazer reportagens: o fotojornalismo. E isso no ano de 1906, sendo um dos precursores dessa modalidade no continente europeu. Nesta, a fotografia não era mero acessório na construção da matéria jornalística. Na realidade, estava em suas mãos transformar imagens em texto. Definida a pauta a ser coberta, o repórter fotográfico saía a campo e fazia de sua câmara a pena, a imagem era seu texto.
4. Por ocasião de um estágio realizado na área de conservação e preservação de coleções de fotografias.

5. O café "A Brasileira", situado à rua Garret, no Bairro do Chiado em Lisboa foi fundado em 19 de novembro de 1905 e tornou-se um espaço onde intelectuais, pensadores e artistas se reuniam para conversar e degustar o chamado genuíno café do Brasil. Foi ali que a expressão tomar uma "bica" ganhou as ruas e transformou-se em sinônimo de beber café em Portugal.

6. Propiciada por um estágio em preservação e conservação fotográfica realizado no Arquivo Fotográfico da Câmara Municipal de Lisboa, nessa instituição

7.Exatamente por Joshua Benoliel ter sido considerado, desde o princípio, como repórter fotográfico, não se poderia fazer um recorte metodológico que desconsiderasse as pautas jornalísticas com as quais trabalhava. Eram elas que informavam e norteavam sua produção.

8. Termo que designa o lis boeta. 
9. Monarquista por convicção, tinha trânsito fácil entre os membros da corte e, mesmo após o fim da Monarquia (1910), manteve relações que lhe conferiam certos privilégios. Acostumado ao pequeno círculo das influências políticas, ele próprio sabia como ninguém trafegar nos diferentes círculos sociais, nunca perdendo de vista seu profissionalismo e sendo muito respeitado por isso.

10. Senhora Ada Celina Paula Souza deAnhaia Mello, que gentilmente doou parte de sua coleção para a Biblioteca da FAU-USP.
Mesmo antes de iniciar na llustração Portugueza, Benoliel já tinha atrás de si um vasto repertório de trabalhos realizados como fotógrafo. Isto o tornava um profissional qualificado e com perfeito domínio das técnicas fotográficas, envolvendo uma ampla gama de atividades que exigiam habilidade e prática como, por exemplo, a necessidade de mudanças rápidas das placas de vidro, necessárias no momento de fotografar. Ou ainda, as opções envolvendo enquadramento para a obtenção de imagens que transmitissem a idéia de movimento, suas preferidas. É importante ressaltar que, como bom repórter, necessitava estar no lugar certo, na hora certa, e isto requisitava, como ocorre ainda hoje em dia, conhecimento antecipado dos acontecimentos e livre trânsito por diferentes esferas?.

O diferencial de Benoliel em relação aos demais fotógrafos seus contemporâneos era saber buscar a notícia nunca de forma estática, mas como se ela estivesse em movimento. Suas imagens eram impactantes e informativas. A busca de uma boa imagem custava sempre algum esforço ao repórter fotográfico. Afinal, era necessário, além de oportunismo, fôlego e força para transportar o material de trabalho, que incluía câmara, tripé, placas de vidro usadas como negativos e, em muitos casos, uma escada que o auxiliava na procura de um bom ângulo e de uma visão mais ampla do conjunto dos acontecimentos a retratar. Foram anos tumultuosos e difíceis. Para a população em geral, foram anos de grave crise econômica, onerada por desemprego e muitas, muitas greves. Foram anos de grandes crises internacionais e até de uma Grande Guerra. Eram esses os elementos que serviam como pano de fundo para a produção de suas imagens; o palco era o cenário urbano, onde seus personagens viviam e se relacionavam.

Coleções e seus produtores: organização e trabalho com as fontes

Os fotógrafos são aqui tomados como agentes produtores, com diferenças substanciais de qualidade técnica, iá que um atuava como profissional e o outro utilizava suas imagens como documentação a ser incorporada à relatórios sanitários e/ou pesquisas científicas. O critério de opção pelas imagens deu-se em função das temáticas trazidas e como estas poderiam fornecer elementos de aproximação para abordar os problemas de cidades que se metropolizavam. A composição temática das coleções pode ser observada no quadro a seguir (Figura 1):

A coleção do Dr. Geraldo Horácio de Paula Souza apresenta uma grande coerência, fruto de uma paciente guarda, de sua filha ${ }^{10}$, através dos anos. Muitas imagens possuem legendas e anotações, e indicam claramente os objetivos de seu produtor e sua opção por determinados ângulos e preferências temáticas. Sua organização interna, dividida em temas, é artificial e foi realizada por terceiros, a partir das informações existentes na própria imagem ou através das legendas por ele colocadas. Apesar disso, a coleção não perdeu sua 


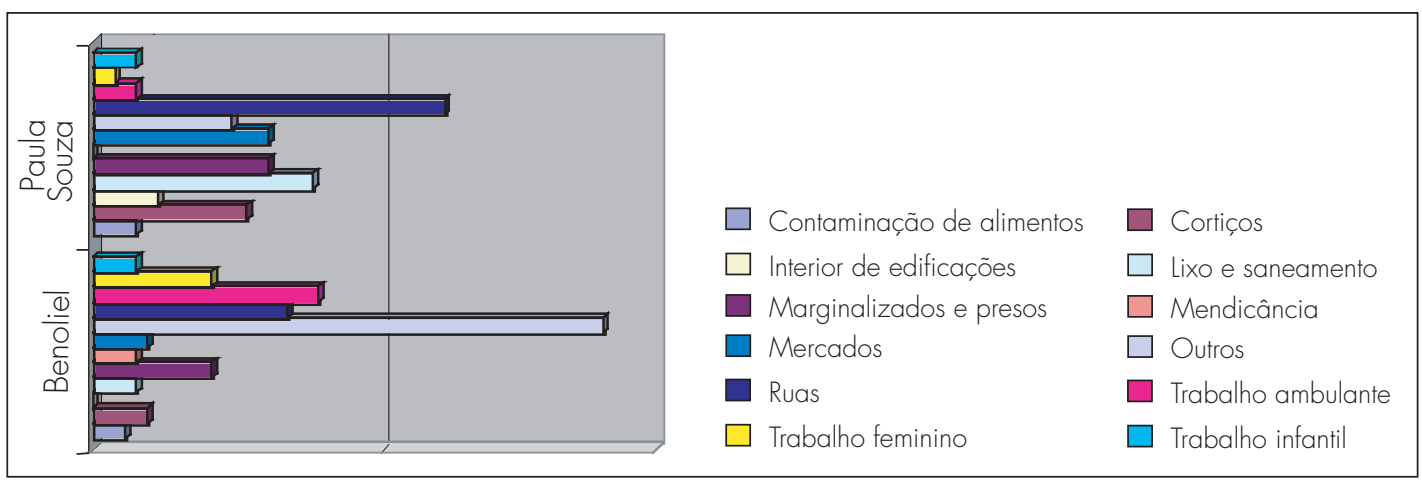

Figura 1 - Composição temática das coleções.

coerência interna e mostra claramente o percurso seguido em sua elaboração. Normalmente, suas imagens recebiam anotações pessoais, escritas em seu verso ou ao lado, nas páginas do próprio álbum. Os registros fotográficos eram gerados a partir de missões fotográficas muito pontuais e específicas, e daí sua organização feita de forma temática, vincando os conceitos e os objetivos de seu produtor. A produção, organizada deste modo, tem um caráter didático e exemplificador. Os temas estão classificados hierarquicamente, apresentando os principais problemas a serem enfrentados pelos profissionais da saúde. Os tipos e espaços urbanos surgidos das imagens são produto de uma reflexão e de uma forma de ver os problemas que o sanitarismo teria de enfrentar. Detectados e exemplificados, o produtor das imagens procura propor soluções (Figura 2).

Já as imagens de Joshua Benoliel, por estarem intimamente relacionadas à sua função de repórter fotográfico, são de uma clareza impressionante e compõem uma crônica urbana sobre a cidade de Lisboa e o seu tempo. Os temas sociais abordados e a vida cotidiana ganham força quando tomados em seu conjunto e relacionados com os difíceis dias de implantação da República portuguesa, em 1910. No caso desta coleção, cada uma das imagens tem seu sentido de produção atrelado a uma pauta jornalística que, por sua vez, está relacionada a um evento social, político, econômico ou cultural. Por isso, a nossa

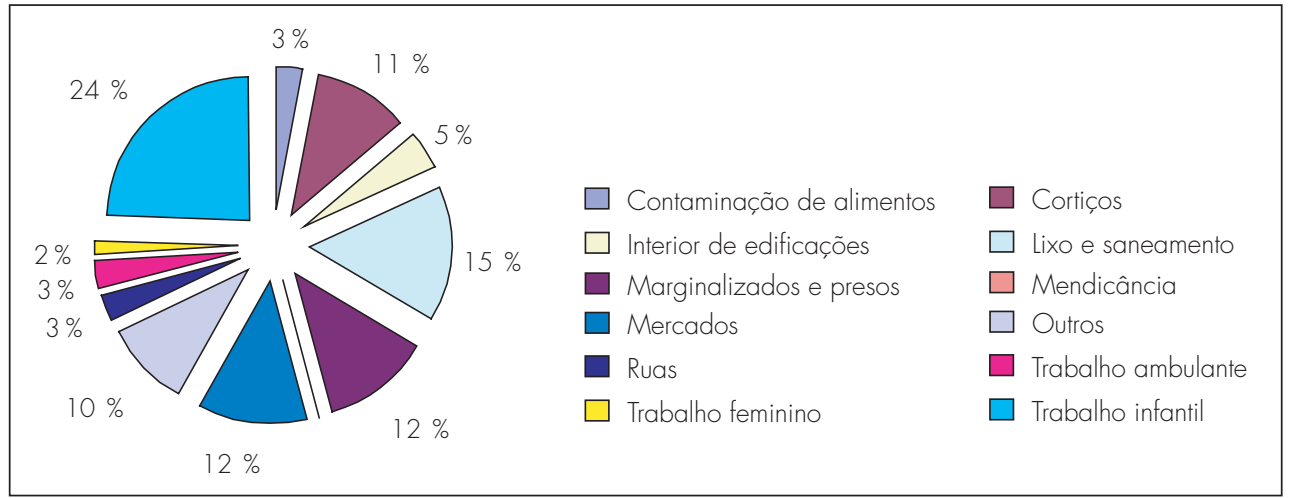

Figura 2 - Distribuição temática na coleção de Geraldo Horácio de Paula Souza. 
11. O resultado dessa investigação gerou um apêndice de mais de cem páginas sobre todas as matérias publicadas na Ilustração Portugueza, com clichês de Benoliel, de 1906 a 1918, disponíveis na tese de doutorado Imagens de Cidade: clichês em foco... (São Paulo e Lisboa, 1900-1928). preocupação de investigação exaustiva da produção jornalística desse fotógrafo, através das publicações geradas para a imprensa lisboeta" (Figura 3).

Seria bom frisar que, no caso do documento fotográfico, temos sempre um objeto único e, portanto, com características muito peculiares. No entanto, se tecermos a rede das tramas que nos trouxeram a estes objetos, sozinhos ou em coleções, chegaremos a horizontes mais amplos. Considerar a imagem fotográfica como um objeto único e, por isso, fruto de uma cultura material, auxilia-nos em momentos onde outras informações parecem não fornecer elementos suficientes para compreendermos a sua produção. A fotografia, neste sentido, passa a representar um todo - composto por seu suporte, técnicas empregadas, eventuais inscrições e carimbos, dedicatórias, assinaturas etc. -, e oferece, por isso, importantes informações sobre aspectos sociais, culturais e estéticos no universo de sua produção, podendo ir além e também fornecer informações técnicas envolvendo áreas do conhecimento exato, como a química e a física, pertinentes ao universo da técnica fotográfica.

Ter claro todos estes pressupostos auxiliou-nos na organização do material trabalhado e indicou-nos os caminhos para proceder à análise.

Detectadas a origem e a forma de produção destes dois fotógrafos, o segundo momento de pesquisa foi procurar a "intimidade" com os temas trazidos pelas imagens. Do reconhecimento em torno da produção de cada um deles, procurou-se dividir as coleções, buscando-se estabelecer permanências de temas, agrupando-os de modo a obter uma espécie de mosaico que espelhasse, de forma coerente, o olhar de cada um sobre a cidade. Neste sentido, as próprias imagens indicavam o caminho a seguir. A partir daí, iniciouse um diálogo entre os registros, buscando-se fazer aproximações e diferenças entre as fotografias no interior de cada coleção, para, em um estágio posterior, cruzar as imagens de cidade entre as diferentes coleções. Foi o momento em que se procurou alinhavar os temas anteriormente soltos em cada coleção, transformando-os em uma única costura, sendo a cidade o tecido e os personagens urbanos as tramas deste. $\bigcirc$ fio para a tessitura destas tramas foi descoberto

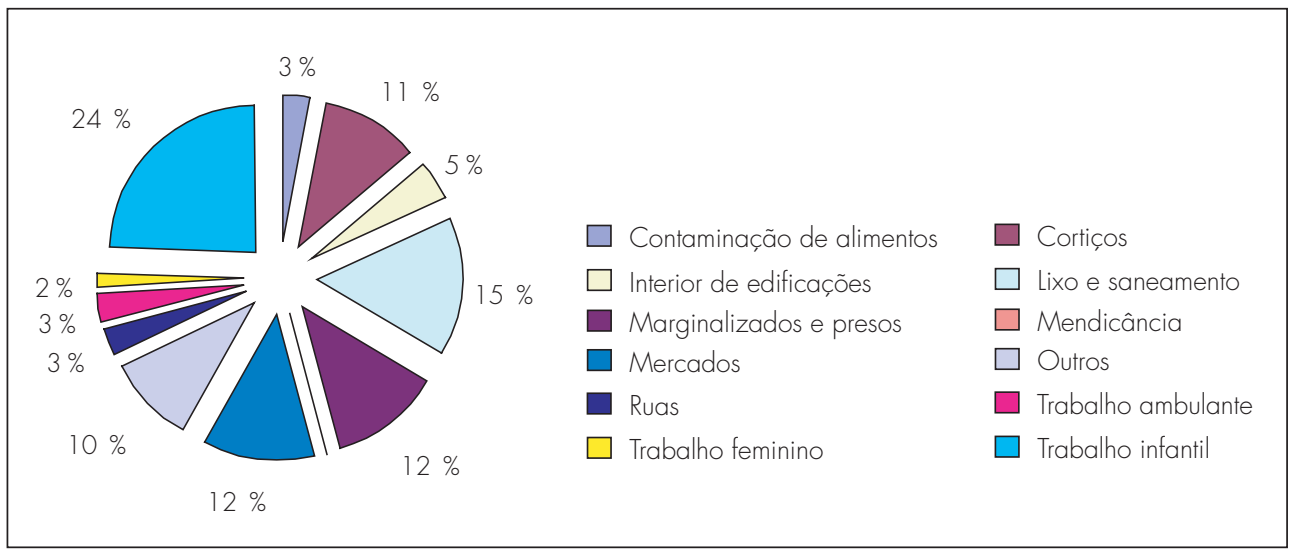

Figura 3 - Composição temática na coleção de Joshua Benoliel. 
mais tarde, a partir da maior familiaridade com as imagens e seus temas. Era necessário encontrar um eixo comum que permitisse o diálogo e o trânsito entre as diferentes coleções.

Trazido pelo contato com as imagens e tomado como porta de entrada para abordar a cidade e compreender a produção das imagens nas diferentes coleções, o eixo de análise do discurso sanitarista possibilitou ver com maior clareza os temas propostos.

As fotografias começaram a fornecer, através de suas temáticas, "janelas" que possibilitavam olhar a cidade. O cruzamento das temáticas, e em muitos casos sua constância, levou à investigação dos motivos pelos quais cada um dos fotógrafos se ocupava destes temas e rapidamente se notou que, na realidade, não eram apenas temáticas destes fotógrafos em especial, mas eram temas de todos os que viviam a urbanidade e a metropolização dos espaços sociais.

Os meandros da investigação das temáticas nos levaram ao contato com diferentes fontes, que acabaram por informar e fundamentar algumas considerações acerca de diferentes problemas urbanos. Estas outras fontes, que serviam como fontes secundárias de apoio, em muitos casos aprofundavam temas trazidos pelas imagens.

Deste modo, o trabalho, que se iniciou a partir de imagens, passou a encontrar comunicação com outras fontes, outros registros que auxiliavam na complexa tarefa de montar o mosaico de olhares dos diferentes fotógrafos.

Dentre as fontes utilizadas no decorrer da pesquisa, encontram-se uma documentação oficial, produzida pelas Câmaras das cidades estudadas, e textos formados por decretos, leis, projetos de lei etc. As discussões realizadas nas câmaras de vereadores foram também tomadas como possibilidade de compreender os caminhos de determinadas leis propostas aos habitantes da cidade. As regras e normalizações para uma cidade que se expande eram, assim, trazidas através de uma documentação oficial.

Além desse tipo de fonte, utilizaram-se relatórios, boletins de ocorrências policiais, dados e tabelas estatísticas, palestras e conferências em congressos, entrevistas radiofônicas e materiais produzidos pela imprensa em geral, como revistas ilustradas e jornais.

A lista de fontes utilizadas inclui, além das citadas anteriormente, relatórios sanitários e administrativos das câmaras municipais, estatísticas geradas pelo sanitarismo e pela polícia, atos, leis, decretos, projetos de lei, posturas municipais, legislação sanitária, boletins sanitários produzidos no Brasil e em Portugal (pelo Instituto Ricardo Jorge), ofícios, discursos realizados na câmara de vereadores de São Paulo, crônicas e relatos de viajantes, e matérias da imprensa diária: Jornal do Comércio, jornal $\bigcirc$ Século, $O$ Estado de S. Paulo; revistas ilustradas (Ilustração Portugueza, O Ocidente e Brasil-Portugal em Portugal; e Fon-Fon!, Vida Moderna, A Rolha para São Paulol, revistas especializadas na área de saúde publicadas no Brasil e em Portugal, teses produzidas pela Faculdade de Higiene e Saúde Pública, palestras proferidas em rádio e congressos 
(Dr. Paula Souza), correspondências pessoais, inquéritos policiais (Carlos Pimenta, 5.- delegado e Armando Soares Cayuby, 6. delegado, ambos em São Paulol, Código Civil Português (1894-1905), além de depoimentos colhidos com descendentes dos dois fotógrafos.

Verificou-se que os conjuntos das imagens traziam temáticas muito próprias de grandes cidades em fins do século XIX e início do XX e eram alvo de inúmeros clichês em diferentes países, indicando-nos que seria possível falar em imagens de cidades. Esta noção reforçou-se ainda mais quando foi realizado um levantamento de imagens produzidas por diferentes fotógrafos em diferentes cidades do mundo como, por exemplo, Eugène Atget, na França; Jacob Riis e Lewis Hine, nos EUA; August Sander, na Alemanha; Allinari, na Itália; e os argentinos George Asfeld, Ernesto Schilie, Cristiano Júnior, Fernando Paillet: quase todos fotógrafos no princípio do século XX e preocupados com as temáticas em torno da cidade. Esse levantamento só serviu para reforçar a convicção de que a cidade era um tema constante para aqueles que produziam imagens no começo do século XX, movidos provavelmente pelo fascínio do ritmo e da velocidade tão presente nas cidades desse período. $\bigcirc$ elemento humano foi tratado por cada um deles de modo a também constituir uma crônica urbana. Em todos os casos, os tipos urbanos surgiam de dentro da cidade olhada como fonte de inspiração.

Escrita fotográfica: algumas considerações teórico-metodológicas

Dois são os espaços a se pensar quando se busca ler uma imagem: um é o espaço fotográfico - entendido aqui como o enquadramento, ângulo, luminosidade, nitidez, figuração, que serão dispostos em um determinado suporte (vidro, platina, prata, papel, plástico etc.) -, outro será o espaço em que a imagem é referência: a cidade, entendida aqui nos seus movimentos sociais, aglomerações urbanas, trabalho informal ou mesmo nos conjuntos arquitetônicos e paisagísticos.

No nosso caso, duas eram as situações: de um lado, um conjunto organizado tematicamente e preservado tal qual foi produzido, como é o caso da Coleção Paula Souza; e, de outro, o caso Benoliel, sobre o qual poderíamos dizer havia duas organizações: uma, dada a partir da pauta jornalística da revista llustração Portugueza e do próprio jornal O Século e que se encontra distribuída pelas páginas de ambos; a outra, a forma encontrada pelos arquivos para organizá-las. São bem diferentes as trajetórias de cada conjunto das imagens de Benoliel, já aquele do Arquivo Fotográfico da Câmara Municipal de Lisboa é resultado de uma "quebra" de conjunto e posterior compra de espólio de imagens que tinham apenas que ver com a cidade; enquanto que as do Arquivo de Fotografia de Lisboa (do Centro Português de Fotografia) representam um conjunto de imagens provenientes do jornal $\bigcirc$ Século, com a cobertura de diferentes temas, especialmente os políticos. Em sua maior parte, são imagens 
repetidas, provenientes de idênticas missões fotográficas, fruto da cobertura de pautas jornalísticas.

Além dos aspectos relacionados acima, seria importante retomar aqui uma outra preocupação que norteia os caminhos de uma pesquisa com imagens fotográficas. Esta se refere ao respeito à proveniência ${ }^{12}$ das fontes. Não importa se pesquisadores, se conservadores ou arquivistas, devemos ter sempre clara a origem do material iconográfico trabalhado e utilizado como fonte. É a partir deste princípio que se pode compreender a coerência interna de uma produção e os caminhos de sua circulação. Isto porque, pesquisar com fontes iconográficas não significa reunir grupos de imagens apenas por qualidades estéticas subjetivas, mas, sim, compreender o seu circuito, os caminhos que vão de sua produção à sua preservação. Este respeito à proveniência permite que coleções de fotografias se mantenham unidas e ajudem a espelhar o universo de sua produção, não como realidade, mas como uma forma de representação.

A preocupação em respeitar a proveniência das imagens levou-nos diretamente a reflexões que envolviam os caminhos de sua preservação, indicando com quais objetivos estas imagens tiveram sua integridade garantida através de décadas, enquanto outras se perdiam através do tempo por diferentes razões. Além disso, viu-se a necessidade de buscar contextualizar tais imagens, já que nada é produzido por acaso. Mostrou-se necessário tecer os caminhos do universo de produção das imagens e cruzar informações imagéticas com outros tipos de documentação, abrindo maiores possibilidades de interpretação.

Escrita sanitária da cidade na imagem fotográfica

Com o objetivo de subsidiar o trabalho com as imagens, iniciou-se uma série de reflexões sobre temas que, inerentes a elas, eram tocados de perto pelo sanitarismo. Este foi se transformando em uma possibilidade de tessitura das tramas do tecido social que surgia a partir do contato com os diferentes clichês. Trazido pelas imagens e tomado como porta de entrada, o eixo de análise do discurso sanitarista possibilitou ver com maior clareza os temas propostos para abordar a cidade e compreender a produção das imagens nas diferentes coleções.

Neste ponto, para algumas reflexões, foram fundamentais estudos do período sobre a concepção de sanitarismo ${ }^{13}$ : higiene, circulação, vadiagem, educação, moral, vícios, reclusão laqui entendida não apenas como prisões e penitenciárias, mas também as instituições de saúde mental como os hospícios, hospitais e asilos). Acreditando que, nos fins do século XIX e princípios do XX, O pensamento higienista informava as concepções sobre o corpo físico e social e interferia sobremaneira nas diferentes abordagens do espaço urbano, influenciando práticas, reflexões e intervenções nas cidades do mundo ocidental, este trabalho tem como um dos eixos de análise as reflexões colocadas pelo sanitarismo e a medicina social. Isto porque este é o momento em que a cidade
12. Princípio arquivístico segundo o qual os arquivos originários de uma instituição ou de uma pessoa devem manter sua individualidade, não sendo misturados aos de origem diversa, garantindo com isso a unicidade do documento. Ver Camargo e Belloto (Coord.) (1996, p. 61 e 76).

13. Do latim salubritas, -atis (séc. XVI), derivado de saluber, -bris, -bre: saudável. Conjunto de condições propícias à saúde. 
passa a ser objeto e agente da principal questão colocada pelas transformações daquele período histórico: a questão social.

sanitarismo, neste sentido, passava a emprestar um repertório às reflexões sobre o espaço urbano. Começam a ser recorrentes termos como higiene, circulação, habitação, desinfecções, circulação, miasmas, esgotos. Neste sentido, o discurso sanitário se desdobrava em seqüências que teciam as tramas discursivas em torno da cidade e ofereciam diferentes imagens dela e de seus problemas. Era ele que estaria informando e alimentando diferentes concepções do que vinha a ser o problema social e, portanto, utilizadas nas construções críticas e denúncias através da imagem fotográfica.

Todo um arcabouço e aparato de regulamentação da cidade passava a ser utilizado pelos que, de alguma forma, tentavam normalizar os espaços urbanos e, em especial, as atividades que envolviam diferentes formas de troca e circulação de mercadorias. Era um momento-chave, de transição de uma economia informal para a constituição de um mercado formal, em que se colocavam novas regras sociais, regulando e regulamentando relações sociais. Era do pensamento higienista que urbanistas e outros técnicos interferiam no espaço urbano: modificando, transformando, construindo novos espaços de convivência e regulamentando antigas formas de socialização e vida.

Os odores passavam a ser detidamente investigados e começavam a ser encarados como sintomas de eventuais patologias. Espaços onde a circulação do ar poderia trazer prejuízos tornaram-se alvo de atenção de diferentes especialistas: hospitais, cemitérios, matadouros, feiras, cortiços etc., eram detidamente investigados; e políticas sanitárias passavam a ser aplicadas. Iniciava-se, com isso, a adoção de medidas higiênicas de regulamentação dos espaços da cidade, especialmente em áreas de aglomerações humanas. Novas posturas em relação aos aspectos ligados à salubridade das cidades gerariam um discurso voltado às questões de saúde pública. Entravam, neste campo, tanto políticas sanitárias, como políticas públicas, envolvendo poderes administrativos e técnicos.

É a partir desse discurso que se acredita que o meio era responsável pela formação moral e física do homem, cabendo a transformação deste meio aos que possuíam conhecimento técnico e competente. Aliadas ao uso de fotografias, as duas linguagens - escrita e visual - teciam um discurso que se relacionava e interpenetrava. Pensar os temas tratados nas imagens inseridas em seu tempo ajuda-nos a lê-las com os elementos que compõem seus códigos de produção, ou seja, não se pode descontextualizá-las de seu tempo e das imagens mentais e ideológicas circundantes.

Tal forma de pensar os códigos visuais que necessitam ser apreendidos pelos que desejam ler as imagens aproxima-se do que Chartier coloca para o caso da leitura: a questão de ter havido, no decorrer da história, diferentes protocolos de leitura, que eram transmitidos e ensinados. Chartier, mencionando a diferença existente entre o escrito e o lido, esclarece: 
[...] a leitura não está, ainda, inscrita no texto, [...] não há, portanto, distância pensável entre o sentido de que the é imposto (por seu autor, pelo uso, pela crítica, etc.) e a interpretação que pode ser feita por seus leitores: conseqüentemente um texto só existe se houver um leitor que para the dar um significado $[\ldots]^{14}$.

Partindo destas idéias, a tarefa do historiador seria procurar

[...] reconstruir as variações que diferenciam os "espaços legíveis" - isto é, os textos nas suas formas discursivas e materiais - e as que governam as circunstâncias de sua "efetuação" - ou seja, as leituras compreendidas como práticas concretas e como procedimentos de interpretação $[\ldots]^{15}$

Para a fotografia, os diferentes protocolos de leitura estariam atrelados, em especial, aos processos fotográficos e à sua utilização por diferentes profissionais e áreas. Neste sentido, o domínio das diferentes técnicas de produção interferiria não apenas na própria produção, mas também na circulação dessas imagens (não se pode esquecer que os processos muito bons em termos de resolução técnica não conseguiram ter no público consumidor a mesma aceitação, quer por causa dos preços, quer pelo resultado obtido: pensar nas fotografias a carvão ${ }^{16}$ e os cianótipos, ambos com ótima qualidade técnica, mas que não obtiveram os resultados esperados junto ao público, o primeiro, pela dificuldade de produção, e o segundo, por deixar um tom azulado nas imagens, ocorrendo exatamente o contrário com processos que apresentavam uma resolução inferior).

Chartier nos instiga neste sentido e comenta:

[...] as estreitas relações estabelecidas na tradição ocidental entre texto e imagem, leitura do escrito e "leitura" do quadro incitam a colocar como centrais as relações entre as duas formas de representação, que sempre se excedem uma à outra, mas que também, como testemunha Poussin, sempre articulam o visível sobre o legível $[\ldots]^{17}$.

A leitura do quadro (tal como a leitura do escrito) pressupõe que haja uma apropriação por parte de quem lê tais discursos e elabora-os a partir de um repertório muito próprio. Obtêm-se, com isso, diferentes níveis de leitura ${ }^{18}$, que irão das intenções e objetivos do fotógrafo - que ao sugerir um tema a ser fotografado imprime ali a sua marca, indicando quais caminhos trilhou - até o uso e as eventuais reflexões dos que se apropriam destas imagens - incluem-se aí antropólogos, cientistas sociais, historiadores, semiólogos etc.

Desta maneira, a grande preocupação como historiadora foi a de tentar utilizar a fotografia como meio de captar o significado que a imagem tinha para seu produtor. Imagem aqui tomada num sentido mais amplo, ou seja, o de ser uma forma de visão de mundo tal como a forma discursiva é uma forma de visão. Se encararmos a fotografia como uma linguagem, ela será vista como fruto de relações sociais produzidas em um determinado tempo histórico, que ajudam, de alguma forma, a reconstituir um determinado período. Pensando assim, a fotografia não vem a ser reflexo do real, e sim uma das muitas formas de apreender este real.
14. Cf. Roger Chartier (1998, p. 11).

15. Idem, p. 12

16. Processo criado por Alphonse L. Poitevin (18191882) e aperfeiçoado por John Pouncy (1818-1894) (TURAZZI, 1995).

17. Idem. Ibidem.

18. Seria interessante, neste ponto, pensar a questão dos diferentes níveis de leitura das imagens fotográficas, em relação ao que ocorria no período de disseminação da leitura nas sociedades européias. Segundo Chartier, neste período de ampliação da alfabetização, existiam o que denominou "protocolos de leitura", adequados a cada época, e que nos fazem pensar o mesmo, com pertinência, para as imagens fotográficas. Ou seja, de acordo com os diferentes momentos de divulgação e apropriação da imagem fotográfica, estabeleceram-se diferentes "protocolos" para sua "leitura".Tais protocolos estariam relacionados, em especial, às diferentes tecnologias utilizadas na produção dos registros fotográficos 
Os fotógrafos trabalhados são tidos como cronistas da cidade. Cada um ao seu modo e maneira imprime sua marca e sua visão de cidade. Esta forma de ver pode ser identificada não só nos temas escolhidos para fotografar, mas também nos tons, nas técnicas empregadas, nos espaços visitados, nos formatos e, até, na disposição, dentro do espaço fotográfico, dos elementos fotografados.

O trabalho aqui apresentado não pretende ser nem a somatória das diferentes imagens e nem a segmentação das mesmas por agência produtora, mas, antes de tudo, pretende ser um discurso sobre a cidade, em que cada imagem dialoga com as demais produzidas sobre o mesmo tema. $O$ eixo de construção deste diálogo entre as diferentes imagens está no discurso sanitário e pretende contribuir com um dos muitos olhares possíveis sobre a cidade.

De veias e artérias: nas praças e pelas ruas, em túneis sob pontes

É desta imagem da rua como artéria, cada vez mais comum em fins do século XIX e início do XX, que partiremos para iniciar nossa análise sobre a cidade. Se tomarmos a cidade como um corpo social, suas ruas seriam artérias que funcionariam como meio de circulação da vida, por onde, obrigatoriamente, os produtos para a sua manutenção encontrariam o caminho para trafegar. Esta forma de pensar a cidade como organismo podia ser encontrada por toda parte, e quase sempre era utilizada para justificar políticas de intervenção no espaço urbano.

A limpeza dos espaços, das ruas, das casas e dos corpos passava a ser considerada fundamental para a salubridade e condutora de princípios ligados à boa ordem e moral, tornando os indivíduos virtuosos e civilizados. Segundo um ditado corrente no período, a higiene seria fundamental para a boa moral de todos os homens, iá que "a virtude se assenta no meio"19.

Desta política saneadora resultava uma profunda tentativa de reordenação dos espaços a partir de um saber competente, no caso, o pensamento higienista. Das remodelações dos espaços públicos e das transformações vivenciadas a partir daí, surge uma lista extensa de temas amplamente encontrados na documentação analisada: problemas relacionados ao abastecimento de gêneros alimentícios e água, destino do lixo e outras formas de rejeitos, serviço de limpeza urbana, a manutenção da ordem e as questões de administração de problemas políticos e sociais, a ocupação do solo e questões ligadas à produção industrial e manufatureira, entre outros.

Tais problemas não seriam diferentes na São Paulo e na Lisboa do começo do século XX. As duas cidades viviam um amplo processo de metropolização e assistiam, dia a dia, sua população aumentar e, com ela, todos os problemas relacionados à sua administração. 
Considerado por muitos como o quintal da Europa, Portugal entra o 13 dez. 1910 século XX sob diferentes contradições, tendo de lidar com uma economia deficitária e com a miséria das populações urbanas, que enfrentavam, além da pobreza e péssimas condições de vida, o perigo sempre crescente de doenças exterminadoras, como o tifo e a tuberculose; e, também, com o constante êxodo no campo como resposta às péssimas condições de vida e de trabalho agrícola, com uma modernização incipiente, e com problemas políticos de várias ordens, que culminariam com a Proclamação da República, em 1910.

Das cidades portuguesas, Lisboa surgia como a possuidora de maior número de habitantes, cerca de 356 mil em 1900, num universo total de 800 mil habitantes em Portugal. Segundo diferentes fontes, em 1900 o analfabetismo chegava a atingir cerca de $70 \%$ dos homens e $85 \%$ das mulheres.

$\bigcirc$ aumento no número de veículos na cidade, além de diminuir distâncias, trazia para o universo urbano novos problemas, estes de relacionamento entre homens e máquinas. Os registros de acidentes envolvendo automóveis e os registros de atropelamentos começavam a aumentar. Os automóveis ganhavam a rua, e, já em 1901, surge o Primeiro Código de Estrada português, determinando como velocidade máxima os $10 \mathrm{~km} / \mathrm{h}^{20}$. Pelo mar chegavam navios, fragatas e outros tipos de embarcação, de onde provinham o alimento e os produtos para a vida lisboeta. Era através de seu porto que Lisboa via chegar e partir migrantes e imigrantes, riquezas e trabalho.

Ritmos e sons na Paulicéia

Tal como Lisboa e outras capitais do mundo nos princípios do século XX, São Paulo também via sua vida urbana crescer e modificar-se. Assistia atônita a uma gama imensa de transformações nos seus hábitos de vida. As ruas da Paulicéia encontravam, por parte dos que a administravam, problemas de todas as ordens e constantemente eram alvo de acalorados discursos realizados na Câmara Municipal ou mesmo na imprensa diária, onde os problemas urbanos ganhavam o tom de reivindicações populares.

São Paulo convivia com um aumento indiscriminado de sua população originária, desde os tempos da imigração na cidade, logo após a abolição da escravatura. Com a imigração, não apenas mais pessoas passaram a ser incluídas nos censos. Novos hábitos e rotinas de vida foram acrescentados ao viveres, na cidade e dela. Temperos, sabores e alimentos ganhavam os tons de diferentes nacionalidades. No ramo das bebidas, a cervejaria ganhava influência alemã e encontrava número crescente de adeptos entre os paulistas. Para os vinhos, a influência vinha de diferentes povos: portugueses, espanhóis, franceses, húngaros, italianos, alemães, entre outros. 
O burburinho aumentava e o ritmo de vida se acelerava, gerando, cada vez mais, políticas que visavam a regulamentar espaços, gestos e modos de viver a urbanidade. Temas como o trânsito e o barulho eram tratados periodicamente e, em muitos casos, podia-se verificar a tentativa de inclusão do maior número possível de situações passíveis de punição. Os sons dessa cidade que crescia num ritmo vertiginoso vinham de diferentes meios de transporte, diferentes personagens urbanos e seus pregões, feitos para chamar atenção ao seu trabalho, ou mesmo de animais que trafegavam soltos por ruas, ruelas e avenidas.

Em ritmo de abastecimento... a cidade alimenta-se

O primitivo triângulo central paulista parecia diminuir de tamanho diante do aumento do tráfego de bens e mercadorias. $O$ trabalho ambulante aumentava e encontrava grande variedade de produtos comercializados nas ruas, nas praças, e de casa em casa. Dentre os mais citados em documentação oficial e com maior número de imagens nas coleções de fotografias, estavam os mercadores de hortaliças, verduras e legumes; mercadores de vassouras; vendedores de jornais, de bilhetes de loteria, de sorvetes, de castanhas, de pescados, entre outros.

As imagens analisadas incluem clichês de diferentes trabalhadores urbanos e, dentre estes, por exemplo, estão o verdureiro ambulante (Figura 4) retratado por Geraldo Horácio de Paula Souza. Em seu carrinho contendo diferentes produtos, o trabalhador saía diariamente em direção aos bairros residenciais à procura de eventuais compradores. Em muitos casos, devido ao hábito dos próprios moradores, tais vendedores ambulantes fixavam-se em determinadas esquinas e faziam dali seu ponto de trabalho. Outros, entretanto, percorriam diferentes ruas arrastando seus pesados carrinhos ao som de seus próprios pregões. Objeto da atenção sanitária, o verdureiro trazia à tona a questão das procedências. De onde vinham tais produtos e de que forma eram cultivados e chegavam ao consumidor? Problemas higiênicos, sem dúvida...

O abastecimento destes produtos hortifrutigranjeiros provinha de chácaras existentes nos arredores da cidade, que compunham um cinturão verde ao redor do centro de São Paulo. Sem os rigores de uma fiscalização e com dificuldades de acesso à água tratada, muitos desses locais eram considerados potencializadores de transmissão de doenças via alimentos. Nascidos e crescidos de forma rasteira, a maioria desses produtos conhecia os perigos vindos do contato com um solo contaminado por esgotos sem tratamento, ou mesmo por dejetos depositados de forma descuidada. Daí provavelmente o interesse num mercador ambulante tão específico e merecedor de um registro exclusivo nas anotações do sanitarista. Mas, o alimento também chegava por outras vias que, igualmente, eram analisadas com atenção. 


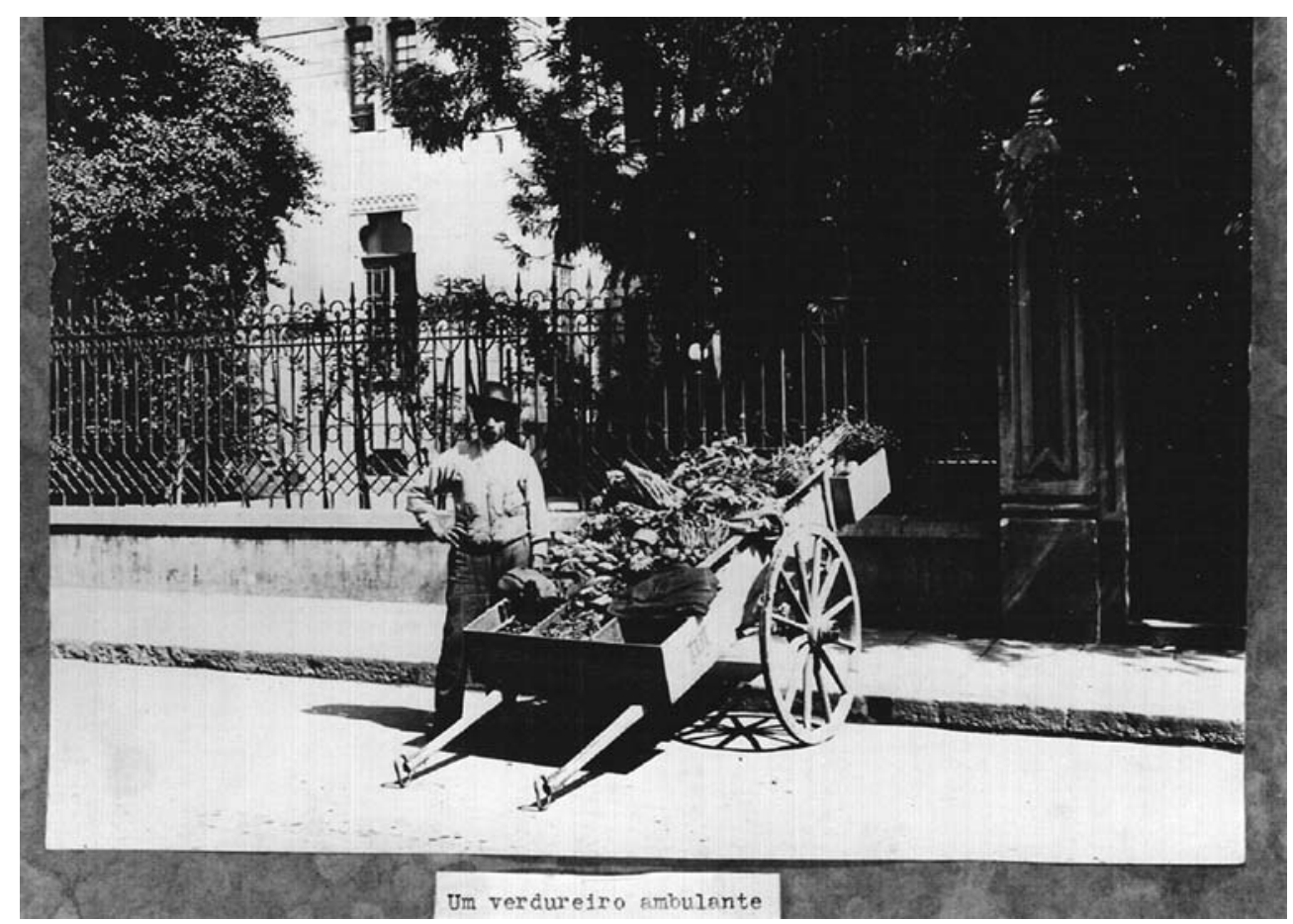

Figura 4 - Geraldo Horácio de Paula Souza. O verdureiro ambulante, 1919-1925, gelatina a partir de Kodak Graflex Auto 4"x 5" Banoh x Lomb. TESSAR, f.45. Acervo da Biblioteca Faculdade de Arquitetura e Urbanismo da USP, São Paulo. Reprodução do Laboratório da FAUUSP.

Mercados e Mercadores

Sempre portador da imagem de trocas - quer econômicas, quer sociais -, símbolo de abastecimento de todos aqueles que não produzem seu sustento, os mercados rapidamente são incorporados à cena urbana e ganham, a partir de meados do século XIX e início do XX, a característica de estarem diretamente ligados às políticas públicas de fornecimento de mercadorias indispensáveis à sobrevivência quotidiana.

Os mercados são uma boa referência quando se procura compreender o sentido de troca e de circulação que, no olhar fotográfico, mostrava-se importante e fundamental para a vida da cidade. É no apregoar constante dentro do mercado que se movimentava e desenvolvia-se a vida urbana. Sob tal olhar, mais do que qualquer outro ponto da cidade, o mercado significava troca. Troca de bens, lugar onde o dinheiro circulava; onde se produziam relacionamentos estreitos entre produtores e consumidores, espaço que nascia normalizado, esquadrinhado e dividido por funções. É deste universo que saíam os diferentes tipos de vendedores ambulantes, devidamente abastecidos, para invadirem com seus produtos as ruas e os bairros de toda a cidade. 
Igual em todas as partes, e fundamental para a vida de qualquer cidade, o mercado representa um campo de forças sociais, onde as políticas de controle visam a manifestar-se. Espaço de trânsito diverso, o mercado oferece variedade não apenas de produtos, mas de condutas e modos de viver. Local onde estratégias de fiscalização e regulamentação de ofertas de mercadorias para consumo são impostas aos que trocam, compram ou vendem suas mercadorias, determinando a constituição de uma intricada rede de produção, distribuição e consumo de produtos.

No universo da produção fotográfica, o espaço do mercado recebe uma atenção muito grande por parte de diferentes fotógrafos. Ponto de encontro para onde convergem produtores, mercadores e consumidores, o mercado oferece a quem dele se ocupa diferentes ângulos de uma cidade. Caracterizado como espaço de troca, o mercado é um convite ao movimento. Movimentos de corpos, transportes, produtos e valores. Sem dúvida, elementos caros às políticas reguladoras e saneadoras.

Em relação aos mercados de Lisboa, sua história retrocede no tempo e tem sua origem nos mercados romanos e árabes dos conquistadores da Península. Como país de vocação marítima, o comércio via mercados sempre esteve presente na vida de seus habitantes e era o espaço de troca dos produtos vindos das conquistas ultramarinas. Seus consumidores desciam das partes altas da cidade em direção aos mercados localizados nos portos e ali encontravam tudo para seu abastecimento: desde produtos de primeira necessidade, como alimentos e roupa, até objetos exóticos vindos de terras distantes, como os produtos da África, do Oriente e do Brasil.

Era dos mercados que saíam, para abastecer as ruas de Lisboa, as vendedoras - exaustivamente fotografadas no desempenho de suas funções de figos, melões, hortaliças e melancias de Benoliel (Figuras 5 e 6, por exemplo). Saíam sempre em grupos, para mais adiante se dividirem, trazendo consigo sempre os filhos que as auxiliavam nas vendas dos produtos da terra. Trabalho feminino, realizado em sua totalidade por mulheres e crianças.

Eram essas as mulheres que, com seu trabalho, alimentavam a vida alfacinha e tiravam daí a subsistência para suas famílias. Alimentavam também uma produção literária e imagética sobre os viveres desta cidade debruçada sobre o mar. Poetas, literatos, cronistas, folcloristas sempre se encarregaram de descrever com cores vibrantes esse trabalho feminino. Vistas como aguerridas, as mulheres de Lisboa, com seu apregoar típico, desfilavam pelas ruas e traziam a quem quisesse os frutos de um trabalho duro: vendiam quase de tudo - de animais a frutas, legumes e hortaliças, peixes e doces -, além de ajudarem no descarregamento de produtos que chegavam pelo mar, como era o caso do carvão, do sal ou da areia. Podiam também ser vistas às portas das fábricas esperando para descarregar cimento, tijolos, gesso ou outros materiais (ABEL, [s. d.], p. 282).

O ganho chegava através de diferentes produtos - como hortaliças, cebolas, peixes, figos, castanhas, entre outros -, comercializados não apenas nas praças dos mercados, mas também na venda ambulante pelas ruas e praças 


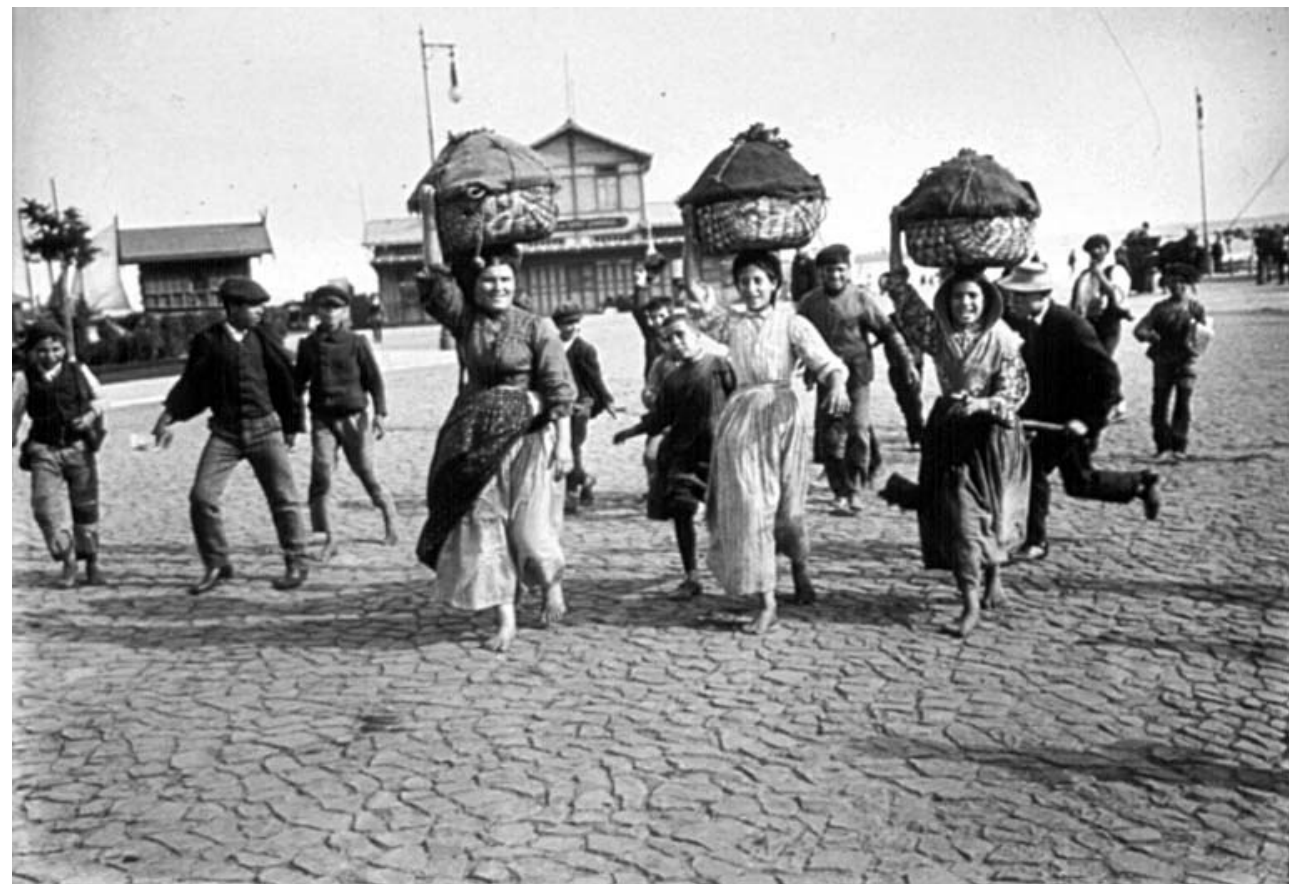

Figura 5 - Joshua Benoliel. Vendedoras de figo no Cais da Ribeira Nova, 1906-1918, gelatina a partir de negativo de vidro. Acervo do Arquivo Fotográfico da Câmara Municipal de Lisboa, Lisboa.

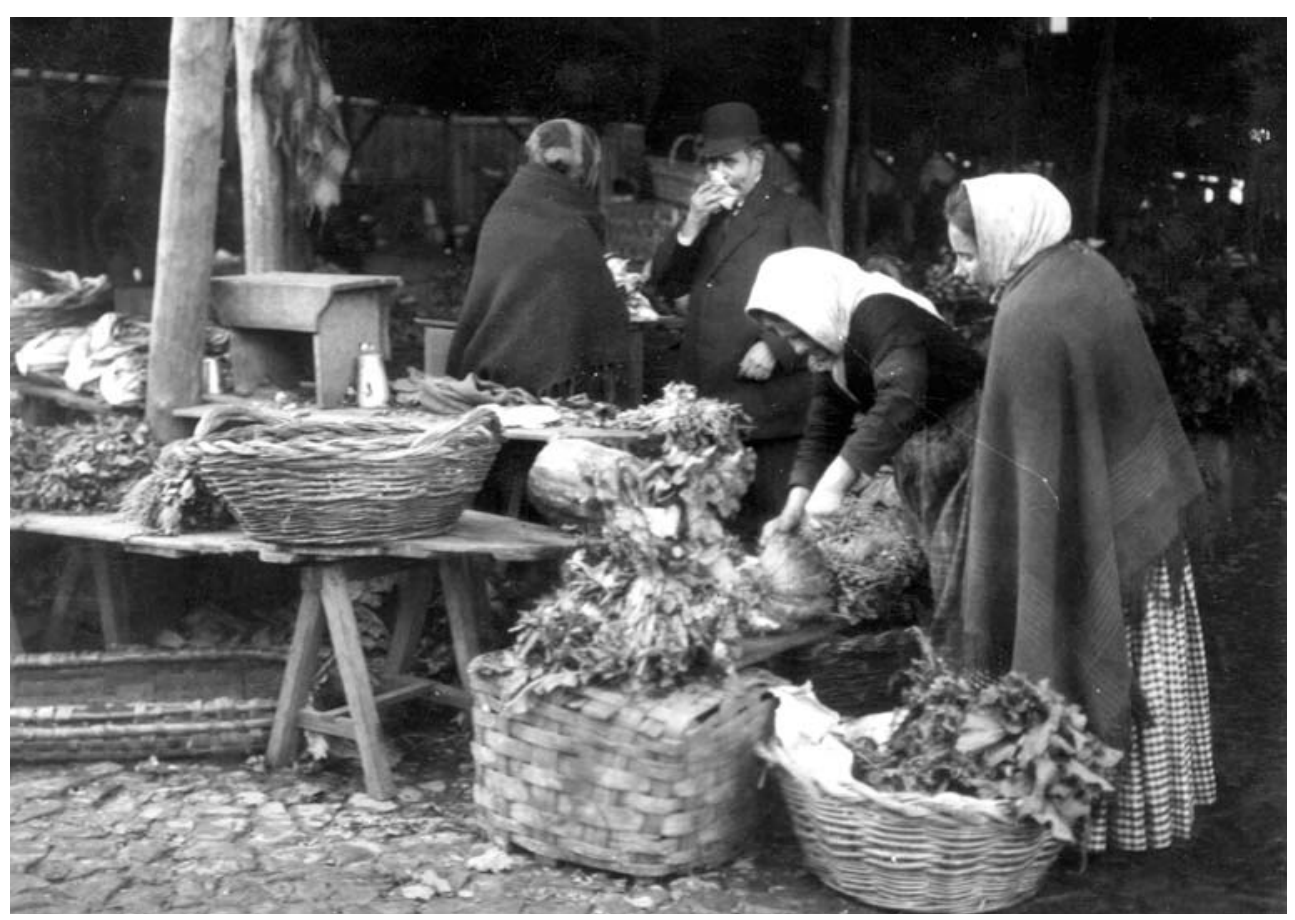

Figura 6 - Joshua Benoliel. Vendedoras de hortaliças, 1906-1918, gelatina a partir de negativo de vidro. Acervo do Arquivo Fotográfico da Câmara Municipal de Lisboa, Lisboa. 
21. Tabela constante no Acto $\mathrm{n}^{\mathrm{0}} 717$, de 23 de setembro de 1914. Coleção Actos e Decretos do Municipio, p. 154 da cidade, que representavam em boa parte um trabalho de subsistência feminino (Figura 7).

Em todos os registros, Benoliel procura o espaço da troca, o momento em que interesses se cruzam. De um lado, o consumidor interessado em obter o que precisa a um bom preço. De outro, o comerciante que procurava fazer de seus produtos um bom negócio. É o caso da Figura 8 , em que a rua é o espaço da troca, da negociação, ponto de encontro de diferentes interesses e possibilidades de realização de negócios.

Mercadejando na Paulicéia

Com uma tradição que nem de longe remonta no tempo, como ocorre com os mercados portugueses, a instalação de mercados na Paulicéia é de origem bem mais recente. Abastecidos pela área em torno da cidade, os mercados contavam com o trabalho de diferentes chácaras que forneciam gêneros alimentícios diversos, em especial os hortifrutigranjeiros. Procurando atentar para questões relativas ao abastecimento da cidade, surgem as feiras livres, em 1914, quando os mercados do Largo da Concórdia e o do Largo do Riachuelo já haviam sido desativados e a Câmara buscava formas de demolir o Mercado do Anhangabaú.

A tradição se manteve no tempo e no espaço, e a venda de folhas e ervas em praças e feiras da cidade tornou-se uma constante, fazendo conviver essa 'medicina' popular com uma institucional, que vendia a cura nas farmácias estabelecidas pelas ruas de São Paulo. Tais feiras funcionavam na cidade e estavam assim distribuídas ${ }^{21}$ :

segundas-Feiras
terças-feiras
quartas-feiras
quintas-feiras
sextas-feiras
sábados

\author{
praça General Osório \\ praça Senador Moraes Barros \\ praça São Paulo \\ praça General Osório \\ rua São Domingos \\ largo do Arouche.
}

Mercados \& regulação: controle de fluxos

Símbolos de vida, circulação e movimento, portadores de diferentes cores, odores e sabores, os mercados traziam para o quotidiano da cidade a multiplicidade de vida ao mesmo tempo em que se relacionavam com o seu contrário. Frutos hoje viçosos e perfumados teriam, no dia posterior, as cores e o odor da putrefação. Fonte de riscos e de preocupações higiênicas. 


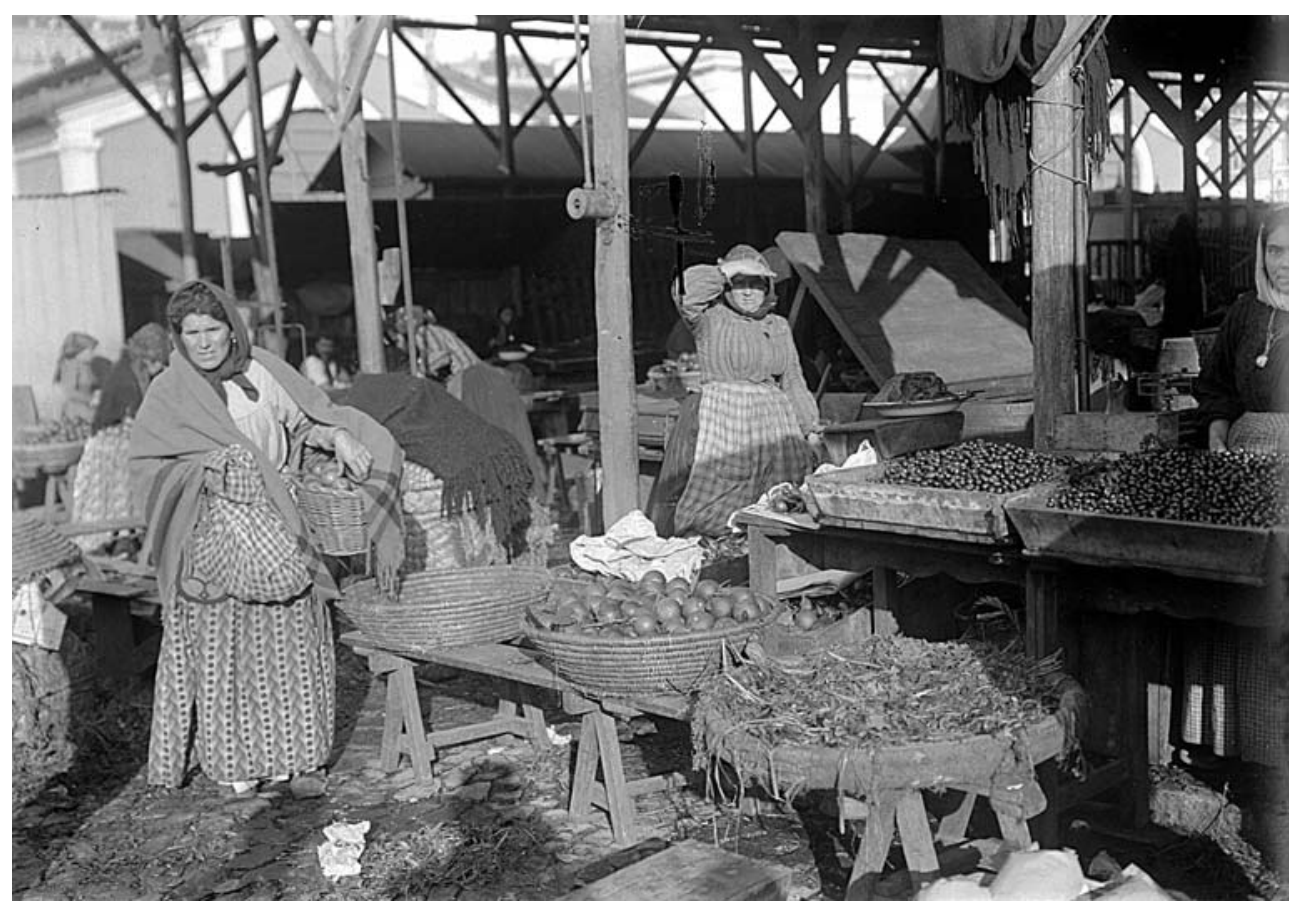

Figura 7 - Joshua Benoliel. Vendedoras de hortaliças, 1906-1918, gelatina a partir de negativo de vidro. Acervo do Arquivo Fotográfico da Câmara Municipal de Lisboa, Lisboa.

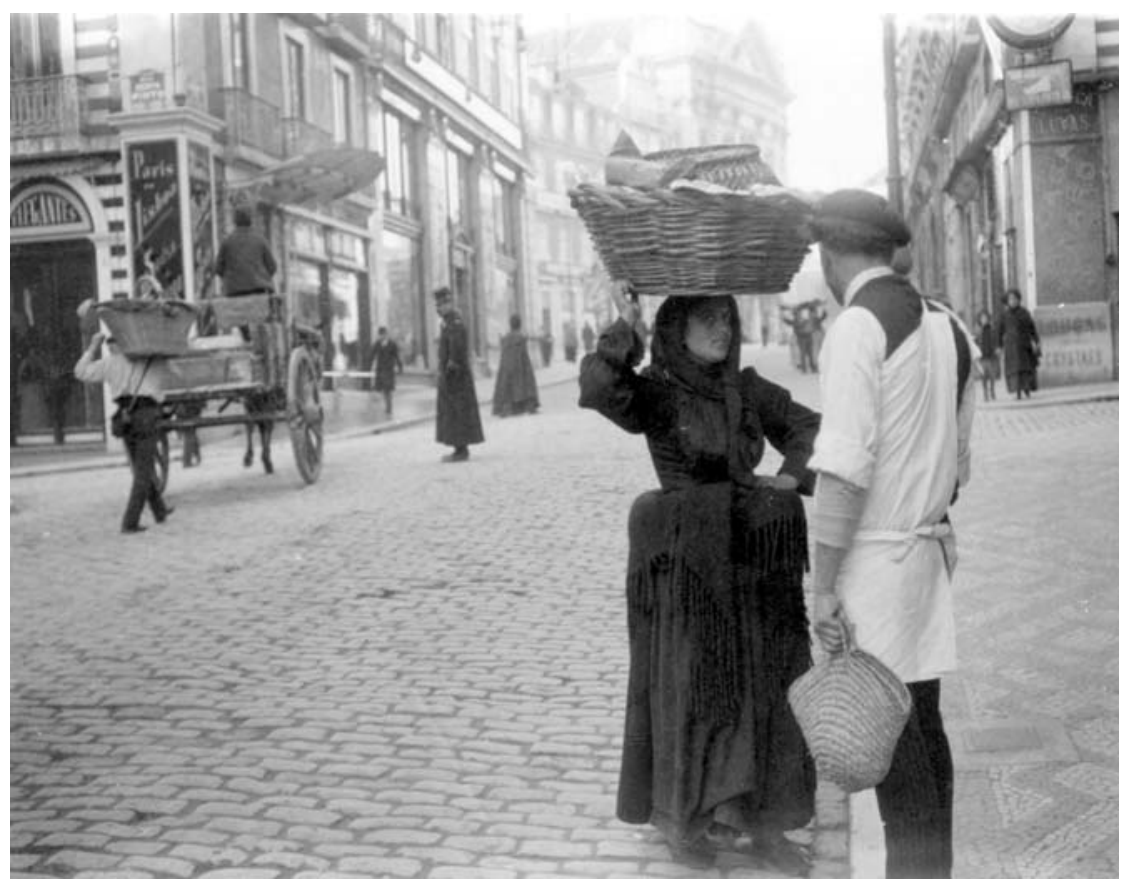

Figura 8 - Joshua Benoliel. Negociando nas ruas, 1906-1918, gelatina a partir de negativo de vidro. Acervo do Arquivo Fotográfico da Câmara Municipal de Lisboa, Lisboa. 

maio 1912.
As acusações contra os mercados, tão festejados quando inaugurados, eram muitas e podiam ser lidas na imprensa, em relatórios sanitários ou mesmo em documentos oficiais dirigidos às câmaras municipais, tanto em São Paulo quanto em Lisboa.

A situação de venda de peixes e hortaliças sempre era apontada como a mais crítica nos diferentes mercados. A tônica sempre girava em torno da questão da água e dos locais onde os produtos eram oferecidos ao consumidor. Diferentes ofícios enviados à Delegação de Saúde abordavam o assunto. Um deles tratava da questão do reaproveitamento do gelo utilizado na conservação do peixe e do rastro de descaso para assuntos ligados à higiene. $\bigcirc$ ofício, redigido pelo então delegado de saúde Manuel Gonçalves e dirigido ao presidente da Câmara Municipal de Lisboa, rezava:

[...] Informa o subdelegado de saude da $13^{\underline{a}}$ circumscripção sanitaria que, no mercado do peixe, é costume aproveitar-se, para revender, o gelo servido nas canastras que transportam o peixe dos barcos para a lota. Esse gelo, bastante conspurcado por contactos com pavimento e valetas do mercado, sempre em pessimas condições de limpeza, volta assim a ser empregado na conservação do peixe dos revendedores, quer em domicilio quer nas remessas para a provincia $[\ldots]^{22}$.

Esse oficio, redigido como forma de denúncia, permite perceber uma indefinição de uso nos espaços do mercado, já que, além de ponto de venda, - local também surgia como uma forma de aglomeração de moradias, onde vida privada confundia-se com vida pública. Os limites eram tênues e muitas vezes se sobrepunham, deixando aos espectadores a impressão de que tudo era apenas uma única coisa. Águas servidas para esgoto ou para a limpeza de roupas sujas eram as mesmas que serviam às bancadas para a venda de hortifrutigranjeiros. Esta situação de uma política ostensiva contra os mercados não se limitava ao caso de Lisboa. São Paulo também tinha seus problemas, e as discussões em torno deles surgiam em diferentes instâncias. Profundamente criticados anos após suas instalações pela cidade, os mercados em São Paulo encontravam, principalmente por parte das autoridades, a insistência em seu banimento da cena urbana. É, por exemplo, o caso do discurso proferido pelo vereador Luciano Gualberto na Câmara do Município, em sessão de abril de 1920:

[...] Matadouro Municipal [...] não passa de um factor de miasmas, de um fóco de pestilencias, em cujas vizinhanças, ao se passar, leva-se naturalmente, o lenço ao nariz, na protecção instinctiva dos pitritas. [...] Há, porém, ao lado deste monstrengo, outro ainda peor e também digno de alguma picareta modernizadora ou, mesmo, de algum bonde piedoso e demolidor da benemerita Companhia Light, que descarrillasse, indo-the de encontro. [...] Refiro-me tambem ao mercado municipal da rua 25 de Março, que, junto ao Matadouro de egual nome, constitue a liga a favor da tuberculose (riso) e de outras affecções de S. Paulo [...].

mercado da rua 25 de Março em São Paulo passava a ser acusado de toda forma de crimes contra a higiene e era identificado principalmente pelas más condições das instalações e pelo odor que dele provinha. $\bigcirc$ vereador se 
detém em diferentes aspectos ligados à salubridade, como ventilação, construção e distribuição dos espaços, além das águas que o serviam. Sua proposta era clara: só sua destruição completa resolveria tantos problemas.

Cinco anos mais tarde, já em 1925 os mercados ainda se apresentavam como pauta de discussão em discursos proferidos na Câmara Municipal. Comentando sobre o chamado mercado dos caipiras, o vereador Julio Silva dizia:

[...] Entrei no mercado pelo portão do lado esquerdo, e qual foi a minha surpreza ao observar, desde logo, um verdadeiro lago de materias provindas dos exgottos das duas unicas privadas ali existentes! É tal o mau cheiro que dahi se desprende que, mesmo á grande distancia, é insupportavel.

Accresce mais, sr. Presidente, que, por sobre essa poça, existem algumas barracas, feitas a expensas dos negociantes, as quaes permanecem immundas, devido ao estado em que se encontra o local. As verduras nesse mercado são atiradas a esmo, por cima até de estercos e são depositadas também sobre os escrementos que cobrem o solo [...].

O seu piso é lastimavel e para a sua cobertura foram aproveitadas as telhas que existiam no antigo mercado. [...] o piso do mercado esta abaixo do meio - fio, mais de um palmo: de sorte que, na occasião das chuvas, a agua ali se acumula. E parece incrivel, que esse é o logar escolhido para deposito de verduras, que, confundindo-se com o lôdo, às vezes, difficilmente delle se distinguem! [...] completa é a ausência de luz, acanhado o espaço destinado ás mercadorias, absoluta a falta de hygiene.

As verduras destinadas á venda são transportadas para o mercado, durante a madrugada. A essa hora, é lugubre o aspecto daquelle local: escuridão completa, muros quasi em ruina - e isso ao lado de montões de lixo, por todos os cantos, donde, por vezes, se despreendem fogos fatuos [...].

Diante de tantos problemas de ordem sanitária, o vereador encerra sua fala com um convite: "[...] Parece-me, sr. Presidente, que a Prefeitura e o illustre sr. Director do Serviço Sanitario, o dr. Geraldo de Paula Sousa, precisam, quanto antes voltar suas vistas para aquelles sitios $[\ldots]^{\prime \prime 23}$.

Não sabemos se, de fato, foi uma resposta a tal convite ou uma preocupação anterior presente na vida de Paula Souza, mas o que de concreto temos é uma série bastante significativa de registros fotográficos dos mercados e feiras da cidade.

mercado, no olhar deste médico sanitarista, era um local para onde convergiam diferentes personagens da vida urbana. Ali estavam os mercadores ambulantes de frutas, verduras, hortaliças, que, com seus cestos de vime, carroças puxadas à mão ou por animais de carga, transportavam seus produtos a diferentes pontos de venda. No espaço do mercado, homens, mulheres e crianças (meninos em sua maioria) distribuíam-se em diferentes funções, e os que de nada se ocupavam inquiriam com seu olhar o cronista fotográfico (Figuras 9 e 10).

No interior do mercado, em clima de festa, o abacaxi era vendido sob um telhado pequeno, por onde entrava a única luminosidade do local, favorecida pela fresta aberta entre os telhados em desnível (Figura 1 1). Lado a lado, os comerciantes partilhavam dos mesmos problemas e dificuldades para a manutenção de suas existências.
23. Sessão na Câmara do Municipio, em maio de 1925 . Coleção Actos e Decretos do Municipio. 


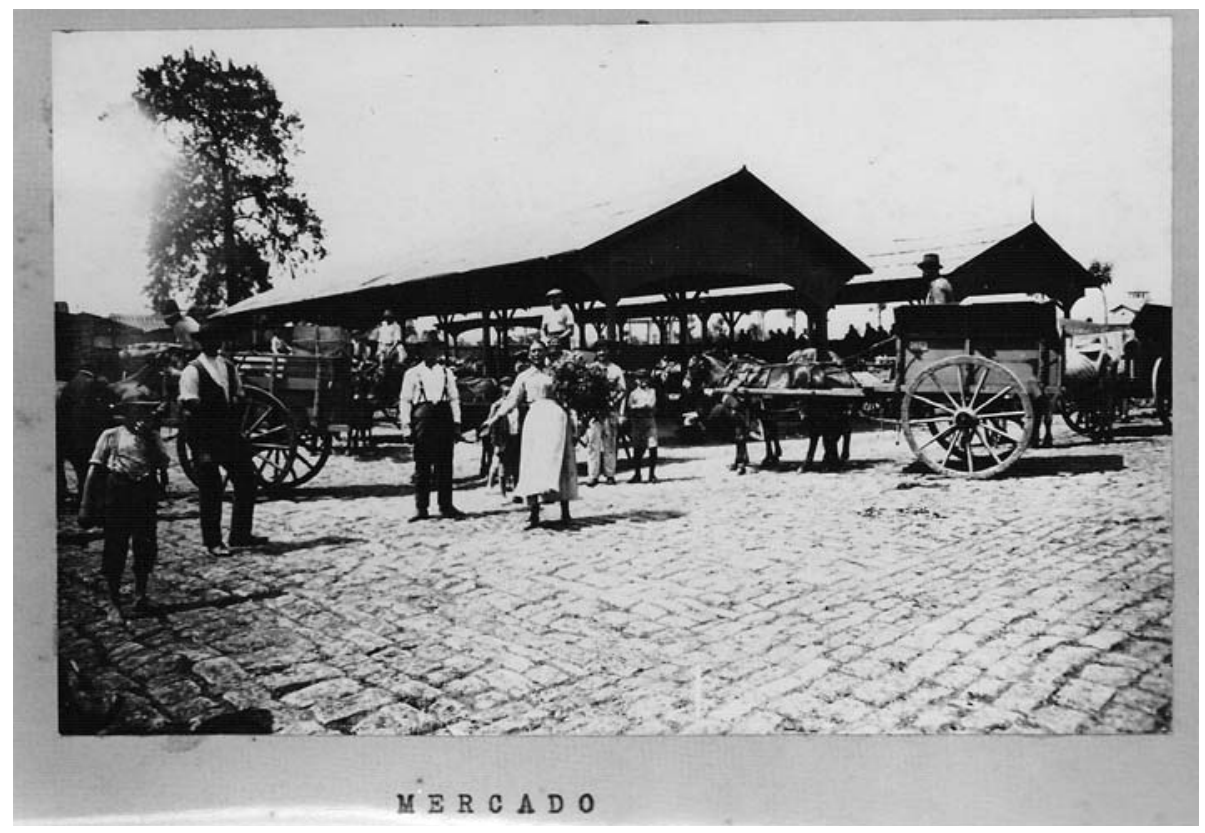

Figura 9 - Geraldo Horácio de Paula Souza. Mercado da rua 25 de Março em São Paulo $1919-1925$, gelatina a partir de Kodak Graflex Auto 4"x 5" Banoh x Lomb. TESSAR, f.45. Acervo da Biblioteca Faculdade de Arquitetura e Urbanismo da USP, São Paulo.

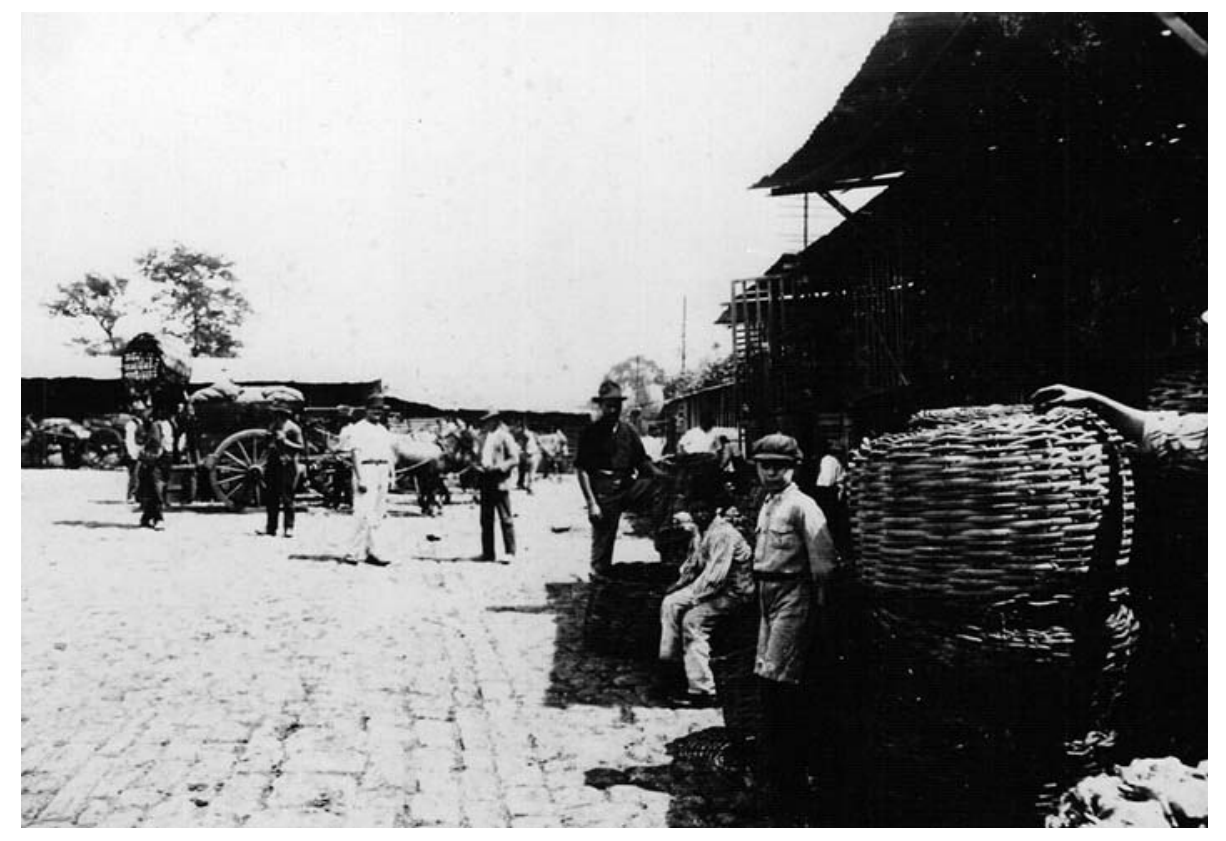

Figura 10 - Geraldo Horácio de Paula Souza. Mercado da rua 25 de Março em São Paulo, 1919-1925, gelatina a partir de Kodak Graflex Auto 4"x 5" Banoh x Lomb. TESSAR, f.45. Acervo da Biblioteca Faculdade de Arquitetura e Urbanismo da USP, São Paulo. Reprodução do Laboratório da FAUUSP. 


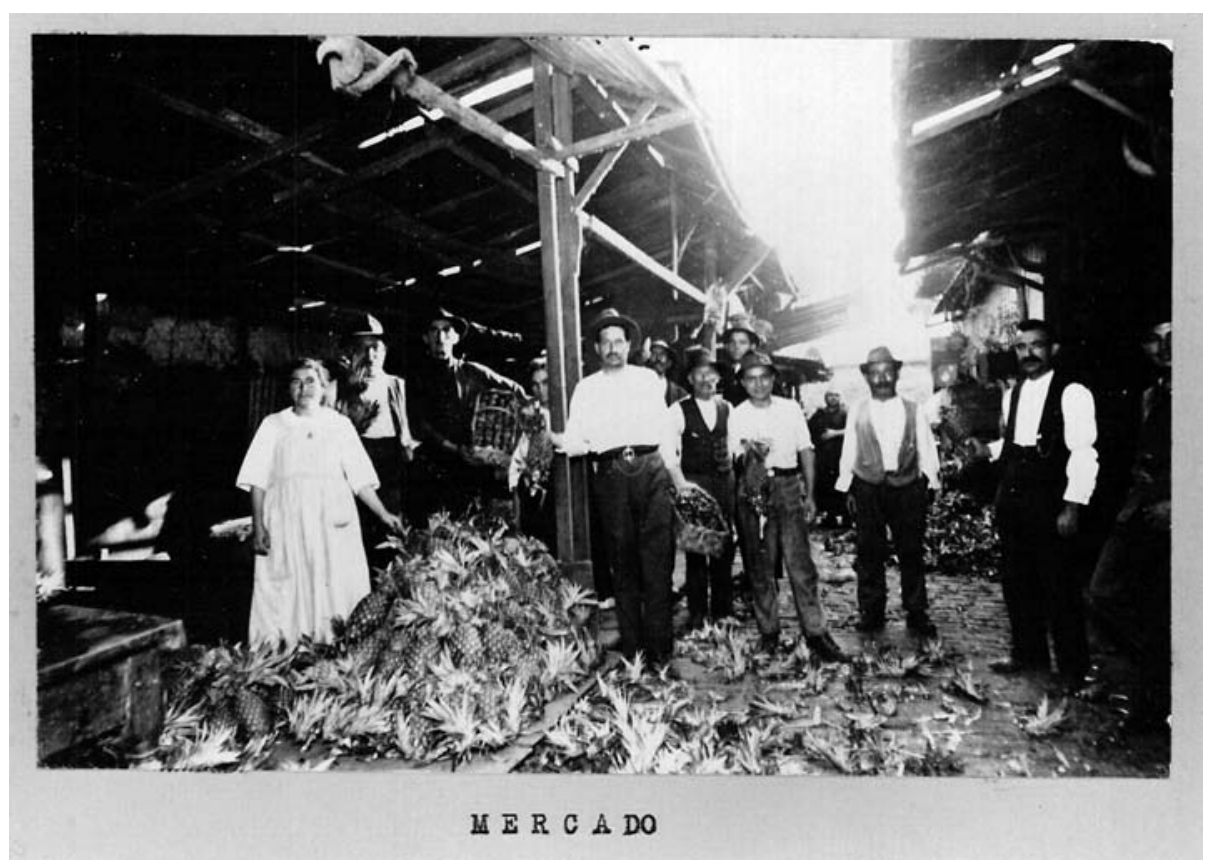

Figura 11 - Geraldo Horácio de Paula Souza. Mercado da rua 25 de Março em São, 1919-1925, gelatina a partir de Kodak Graflex Auto 4"x 5" Banoh x Lomb. TESSAR, f.45. Acervo da Biblioteca Faculdade de Arquitetura e Urbanismo da USP, São Paulo. Reprodução do Laboratório da FAUUSP.

Espaços irregulares, de piso em desnível calçado por paralelepípedos, completamente descobertos são documentados através do registro de Paula Souza e indicavam, ao fundo, os locais destinados ao estacionamento de carroças que cumpriam as tarefas de carga e descarga (Figuras 12 e 13). Talvez seja este o espaço descrito pelo vereador como sendo aquele que ficava cheio de poças d'água e onde o lamaçal dificultava discernir o que era lodo da chuva e o que eram as verduras nele espalhadas.

Como todos os estabelecimentos, os mercados também têm suas entradas. Nelas encontramos diferentes personagens, que poderiam ser classificados em algumas categorias: havia os que aguardavam uma oportunidade de compra e venda de produtos ou aqueles que simplesmente se colocavam à margem, quer como consumidores eventuais, quer como meros espectadores. Fora deste espaço também encontramos diferentes transportes contendo produtos comercializados ou não no interior do mercado. Os registros fotográficos revelam este trânsito de pessoas, bens e mercadorias e, de alguma forma, mostram o movimento existente dentro de suas portas. Não é o objetivo do registro casual captá-las, mas, sim, mostrar as instalações existentes e o tipo de comércio praticado.

São também para as portas do mercado que todos os produtos rejeitados ou não consumidos são levados como lixo e aguardam o momento oportuno para serem transportados para longe (Figura 14). Neste registro, o 


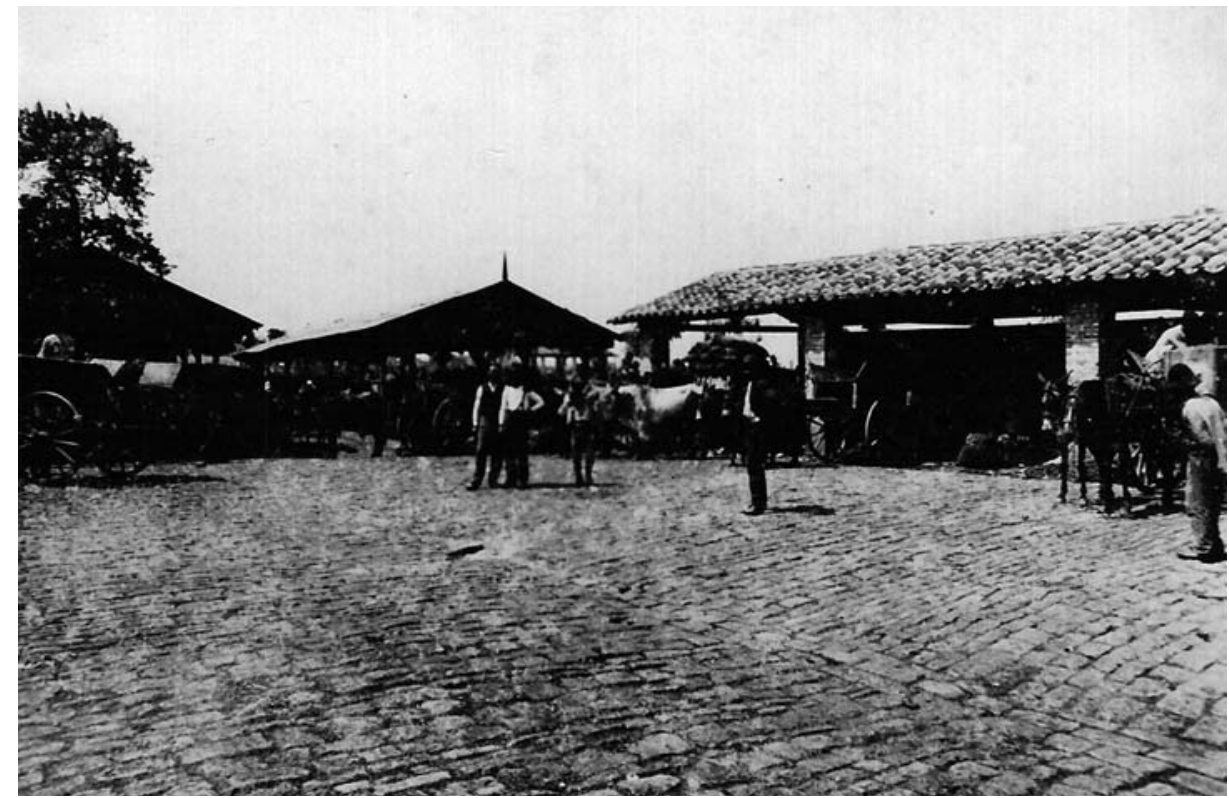

Figura 12 - Geraldo Horácio de Paula Souza. Mercado da rua 25 de Março em São Paulo, 1919-1925, gelatina a partir de Kodak Graflex Auto 4"x 5" Banoh x Lomb. TESSAR, f.45. Acervo da Biblioteca Faculdade de Arquitetura e Urbanismo da USP, São Paulo. Reprodução do Laboratório da FAUUSP.

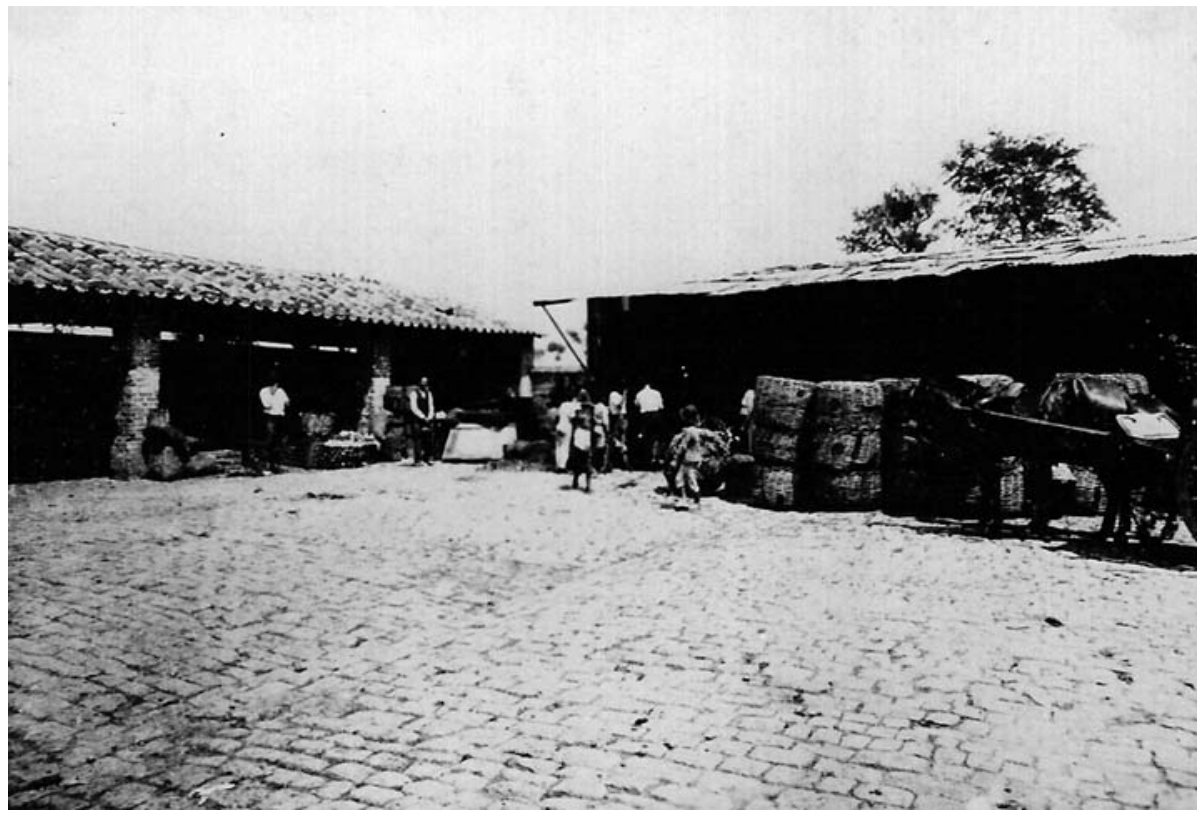

Figura 13 - Geraldo Horácio de Paula Souza. Mercado da rua 25 de Março em São Paulo, 1919-1925, gelatina a partir de Kodak Graflex Auto 4"x 5" Banoh x Lomb. TESSAR, f.45. Acervo da Biblioteca Faculdade de Arquitetura e Urbanismo da USP, São Paulo. Reprodução do Laboratório da FAUUSP. 


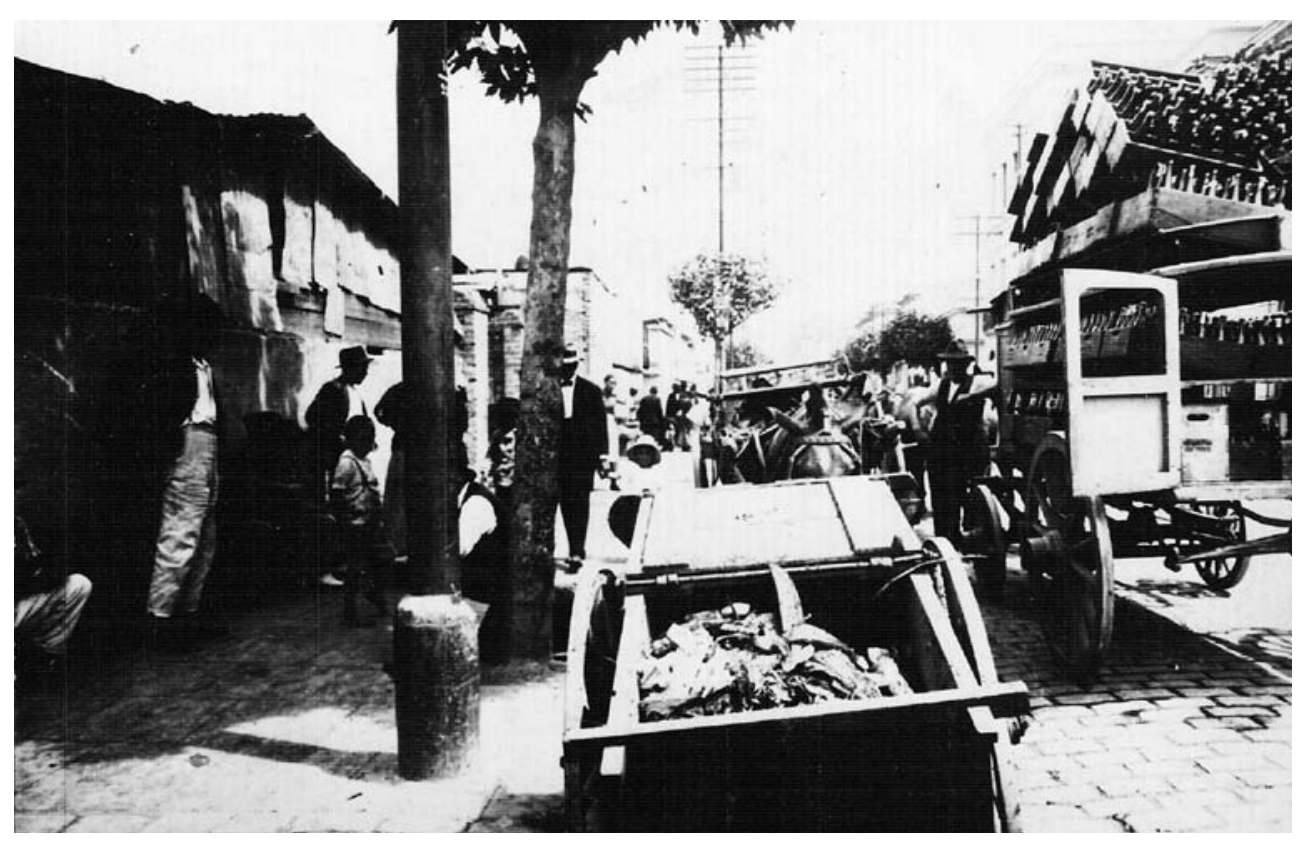

Figura 14 - Geraldo Horácio de Paula Souza. Mercado em São Paulo, 1919-1925, gelatina a partir de Kodak Graflex Auto 4"x 5" Banoh x Lomb. TESSAR, f.45. Acervo da Biblioteca Faculdade de Arquitetura e Urbanismo da USP, São Paulo. Reprodução do Laboratório da FAUUSP.

que nos chama atenção é o local escolhido para a tomada da imagem: a entrada principal de um mercado. Local citado como alvo de críticas quanto a problemas sanitários presentes na comercialização de gêneros alimentícios. Em segundo lugar, em primeiro plano, o registro procurava focar a carroça aberta de transporte de lixo, que aparentava estar simplesmente estacionada, sem qualquer indicação de trabalhadores à sua volta. Isto em si seria alvo de preocupação sanitária, já que o código sanitário era claro quanto à necessidade de o lixo estar sempre tapado e somente quando encontrasse o seu destino, longe no mínimo 200 metros de qualquer residência, é que deveria ser destapado.

A lei especificava que:

Art. 14․ - Terminado o carregamento das carroças empregadas nos diversos serviços, seguirão estas perfeitamente fechadas, sem demora ou parada, até ao logar de destino, não sendo permitida durante o percurso qualquer baldeação ou deposito fóra dos pontos determinados pela Prefeitura $[\ldots]$.

Art. 15․ - [...] As carroças e carrocinhas a que se referem os artigos anteriores, devem ser solidas, estanques, apropriadas ao fim especial a que se destinam e mantidas em bom estado de conservação e asseio.

Estas carroças serão munidas de tampas que fechem completamente, de fórma a não deixar cahir ou vasar parte alguma de seu conteúdo. Essas tampas só serão levantadas para carga ou descarga.

Deverão ser lavadas diariamente e desinfectadas em dias e por processos indicados pela Prefeitura [...]. 
As carrocinhas de mão serão construidas de modo a ocupar espaço diminuto na via publica $[\ldots]^{24}$.

As especificações previstas em lei eram bastante claras e minuciosas, mas, como todas as leis, sabemos do seu alcance e do poder de sua execução...

espaço externo do mercado é mostrado por Paula Souza e parece indicar qual é a fachada deste centro abastecedor (Figura 15). Sua entrada parece estreita e seus muros estão em ruínas pelo tempo e pelo descaso; ao longe se observam os quartos de venda de produtos, muitos com os telhados feitos em retalhos, indicando uma constante improvisação contra as intempéries do tempo. O acompanhamento das imagens revela a preocupação didática de seu produtor e o detalhamento meticuloso de cada espaço, cada canto, cada brecha, cada pessoa em seu interior.

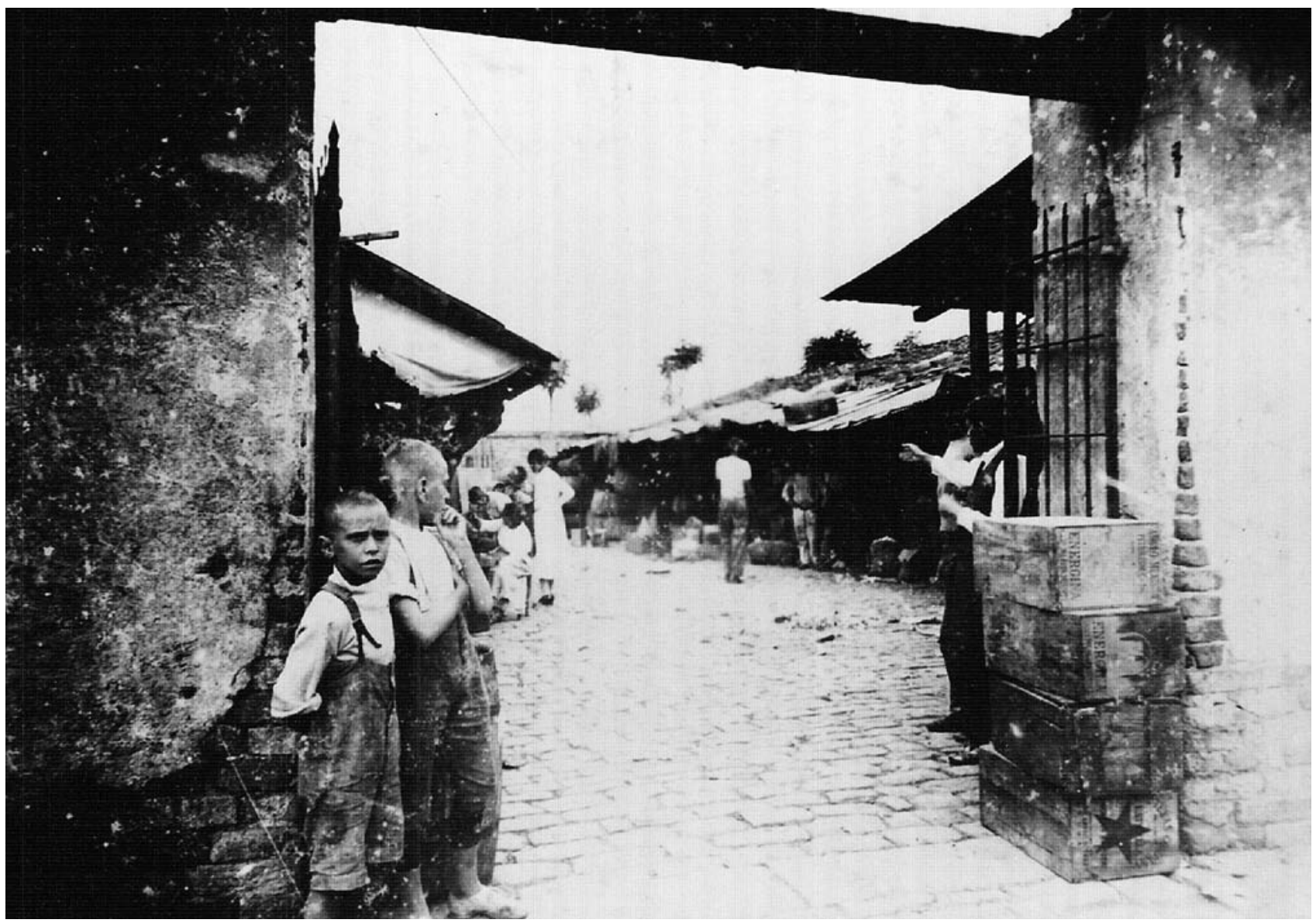

Figura 15 - Geraldo Horácio de Paula Souza. Mercado da rua 25 de Março em São Paulo, 1919-1925, gelatina a partir de Kodak Graflex Auto 4"x 5" Banoh x Lomb. TESSAR, f.45. Acervo da Biblioteca Faculdade de Arquitetura e Urbanismo da USP, São Paulo. Reprodução do Laboratório da FAUUSP. 
Diversos são os trabalhos desenvolvidos por pequenos trabalhadores e, entre outros, incluíam serviços como os de engraxate ou a distribuição de jornais. $\bigcirc$ vendedor de jornais é, sem dúvida, um dos personagens prediletos e representativos das cidades que se metropolizam no princípio do século XX, sendo o tema de inúmeros clichês por todo o mundo.

Segundo diferentes fontes, temos a indicação de que havia uma certa divisão de trabalho não apenas por categorias, mas também por nacionalidade e, neste sentido, pode-se afirmar que cada grupo imigrante acabava por se concentrar em uma determinada área do espaço urbano, desempenhando uma atividade específica. É o caso, por exemplo, dos italianinhos na venda e distribuição de jornais e no trabalho como engraxates, os espanhóis vendendo e comprando ferro-velho, os portugueses no fabrico e distribuição de pão.

Através de diferentes propostas municipais voltadas para estas categorias de trabalhadores, podem analisar-se suas condições de vida e de trabalho. A primeira refere-se a um projeto de José Oswald, na Câmara dos Vereadores de São Paulo, em 12 de novembro de 1904, em que, para justificar a proibição do trabalho de menores na venda de jornais, acaba descrevendo as condições deste trabalho:

É de todos conhecida a perniciosa prática existente entre nós de ser a venda avulsa de jornaes effetuada por menores, os quaes, pela tolerancia dos paes, que, seduzidos por pequeno lucro ou por se aliviarem do encargo da alimentaç?o de seus filhos, os abandonam quasi; elles se entregam á vagabundagem, dormem muitas vezes no relento, andam maltrapilhos, e nessa vadiagem apprendendo toda sorte de vicios [...] assim, e por motivo da ordem moral, a Camara Municipal de S. Paulo decreta:

Art. $1^{\circ}$ - Fica prohibida neste municipio a occupação de menores na venda avulsa de jornaes. Art. $2^{\circ}$ - Os infractores incorrerão na multa de $10 \$ 000$ e nas reincidencias na multa de $20 \$ 000$ e 3 dias de prisão ${ }^{25}$.

$\bigcirc$ projeto põe a nu, em suas entrelinhas, a questão da exploração de menores, realizada por parentes diretos, o que acabava por colocá-los em contato com outras formas de estar na vida, muito mais próximas da delinqüência. Normalmente, como ocorria também para o caso de Lisboa, este trabalho era infantil e praticado por camadas muito pobres da população. Tais meninos rapidamente se transformavam em arrimos de suas famílias e, por pressão, abandono ou excesso de compromissos, largavam ou eram largados de seus progenitores, engrossando estatísticas de menores dormindo nas ruas ou nos vãos de escadas. Era, de fato, uma atividade desenvolvida por classes menos favorecidas e demandava horas de muito trabalho e pouca remuneração. Em muitos casos, tais meninos constituíam o meio de ganho de famílias inteiras.

Os vendedores de jornais, também chamados ardinas ${ }^{26}$, apareceram nas ruas de Lisboa junto com os primeiros jornais. Mas, como ocorria com diferentes cidades do mundo, a imagem mais presente em nosso imaginário são as do final
26. Definidos como rapazes que vendiam, preferencialmente pelas ruas, jornais, bilhetes postais, papel etc. 
do século XIX e princípio do XX, em que meninos descalços, na maior parte das vezes muito magros, sempre munidos de sua sacola, saíam às ruas para apregoar seus jornais e revistas. Segundo Marina Tavares Dias, "Muitos destes rapazes tinham menos de 10 anos; eram geralmente explorados por um "empresário" de bairro que os vestia mal e alimentava pior" (DIAS, 1992, v. 3, p. 51 ).

À semelhança do que ocorria em São Paulo, tais meninos descobriam cedo as dificuldades em ganhar a sobrevivência e a responsabilidade de ajudar ou até mesmo manter uma família. Lisboa os conhecia bem: distribuíam seus jornais pelas ruas da cidade, às vezes em grupos, às vezes individualmente. Conhecidos principalmente pelo jornal que distribuíam, tais ardinas percorriam diferentes pontos da cidade. Benoliel os registra em diferentes momentos, e são eles que, após uma longa greve dos jornaleiros, estão ali a aguardar o momento de voltar a inundar as ruas de Lisboa com o jornal $O$ Século: estão ali ensaiando uma bem-humorada coreografia às portas do jornal (Figura 16). Todos guardando em comum, além da pouca idade, a origem humilde, as roupas rotas e os pés descalços. As sacolas são trazidas a tiracolo, e o gorro identifica os que vêm dos arredores da cidade. Benoliel, aqui, retira o foco do transtorno gerado pela greve na distribuição de jornais com um registro de aparente normalidade e diversão. Nesse sentido, ele repete uma atitude comum em relação às greves:

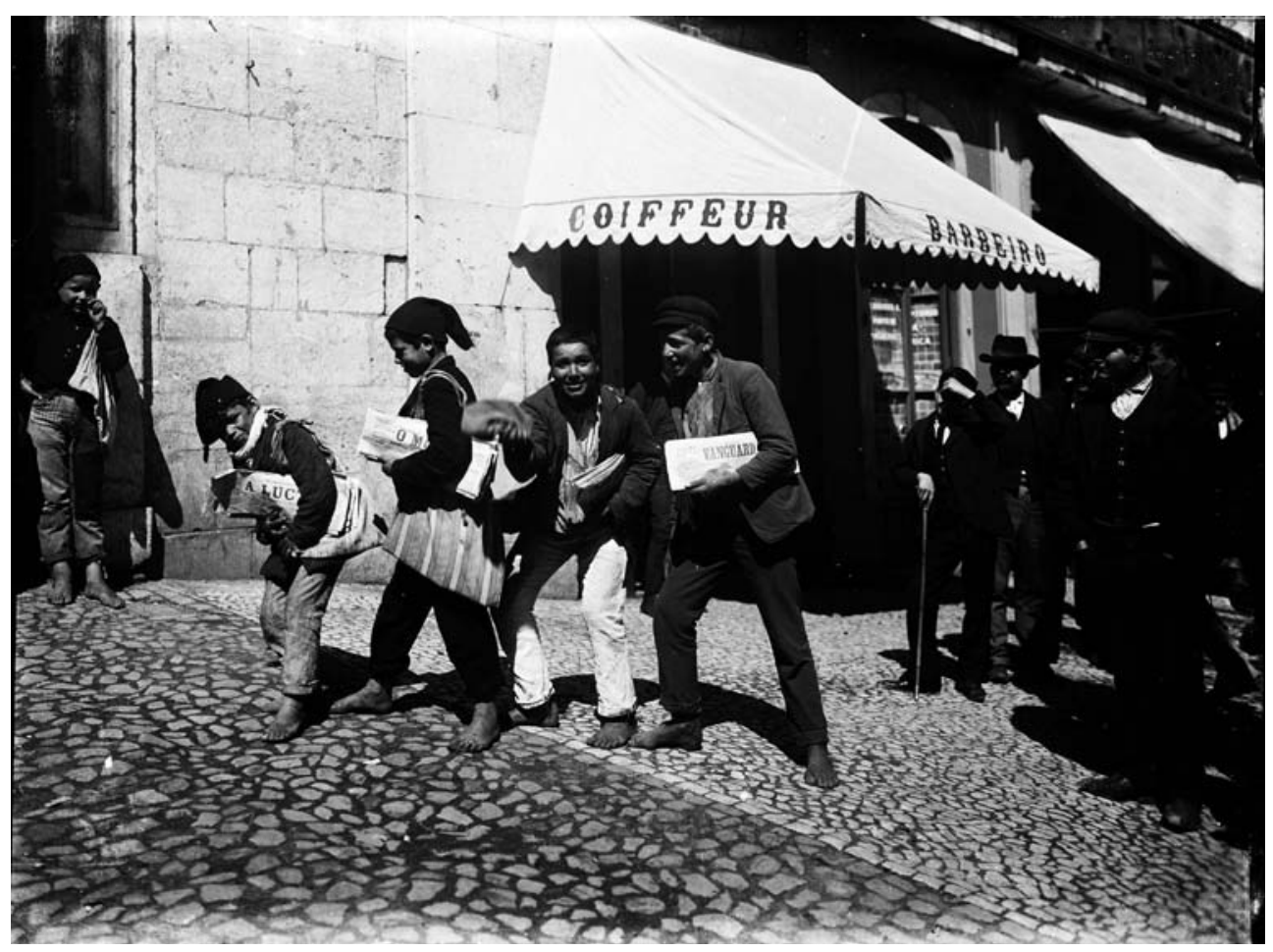

Figura 16 - Joshua Benoliel. Ardinas do jornal O Século, c. 1911 , gelatina a partir de negativo de vidro. Acervo do Arquivo Fotográfico da Câmara Municipal de Lisboa, Lisboa. 
apesar de possuir grande habilidade nos registros feitos com grandes massas, seus registros nunca apontam a desordem e a confusão. A massa de grevistas aparece sempre de forma coesa, unida em torno de um objetivo comum. Também há que se pensar que o registro fotográfico se referia à greve no próprio jornal Século, que era a mesma empresa publicadora da llustração Portugueza, onde essa imagem foi efetivamente publicada.

Dos que trafegavam pelas ruas de Lisboa, Benoliel explora diferentes imagens de trabalhadores urbanos. Dentre eles, podem citar-se, os vendedores de bilhetes de loteria, os vendedores de pescados, de rendas, os entregadores de pão. Todos os clichês procuram mostrá-los no desempenho de suas funções. Estão também retratados os vendedores ambulantes de rendas, hespanholitos que traziam da Espanha pequenos pedaços de tentação colorida em fardos de riscado azul e, carregando-os no ombro, ofereciam-nos de casa em casa ${ }^{27}$; ou o vendedor de bilhetes da loteria da Santa Casa de Misericórdia, que espalhava seu apregoar por todas as ruas de Lisboa, chamando a atenção para o dia da Roda da Fortuna.

Tais vendedores de bilhetes de loteria pareciam estar por toda parte e, especificamente no caso de São Paulo, geravam protestos de autoridades sobre o grande alarido que provocavam nas ruas, junto às aglomerações de pessoas. Na Câmara de São Paulo, por exemplo, várias discussões em plenário sugeriam a proibição de tal comércio, com argumentos, por exemplo, como os colocados por Luiz Fonseca:

É preciso que se note que o tripeiro, o bananeiro e outros vendedores ambulantes apregoam as suas mercadorias nos bairros da cidade, pelas ruas de pequeno transito, sem a insistencia irritante dos vendedores de bilhetes. [...] não só agridem a população, como fazem um berreiro infernal ${ }^{28}$.

projeto, no entanto, é rejeitado, e a cidade continua a contar com as vozes dissonantes dos vendedores de bilhetes de loterias, que tiveram sua profissão regulamentada em lei de $1911^{29}$.

Em esquinas, por becos e ruelas

Em diferentes pontos, por vezes em esquinas, ruelas, becos e calçadas, diferentes trabalhadores aguardavam sua sobrevivência, que vinha através do trabalho oferecido pelas ruas. Normalmente, tal como ocorria em São Paulo, eram os jovens e crianças, vivendo em áreas de exclusão social, que seriam os principais protagonistas das imagens de Benoliel: eram os limpadores de chaminé (Figura 17), os engraxates, os galegos ${ }^{30}$ aguadeiros $^{31}$, entre outros, que ajudavam a construir esse espaço urbano. As imagens captadas destes trabalhadores infantis conseguiam extrair de seus comportamentos uma certa solidariedade e camaradagem próprias dos jovens, que, apesar do trabalho difícil, ainda
27. Os registros de Benoliel sobre este tipo de trabalhador podem ser verificados em imagens que compuseram uma reportagem para a Ilustração Portuguesa, que tratava do trabalho de venda de rendas realizadas de casa em casa. Aviamentos, tecidos, fitas e brocados eram trazidos por esses espanhóis e encantavam portuguesas de diferentes classes sociais O comércio para bens pessoais e de consumo chegava de porta em porta, trazido por diferentes ambulantes.

28. Parecer $n^{\circ} 48$, da Commissão de Justiça, pedindo revogação do art. 13, da lei $\mathrm{n}^{\circ} 2162$, de 26 de outubro de 1918. ColeçãoActos e Decretos do Município de S. Paulo.

29. Lei $n^{\circ} 1397$, de 23 de março de 1911,p.29. ColeçãoActos e Decretos do Município de S. Paulo.

30. Referência aos provenientes da região da Galiza, norte da Espanha.

31. Eram aqueles que vendiam e carreavam água para os habitantes da cidade. 


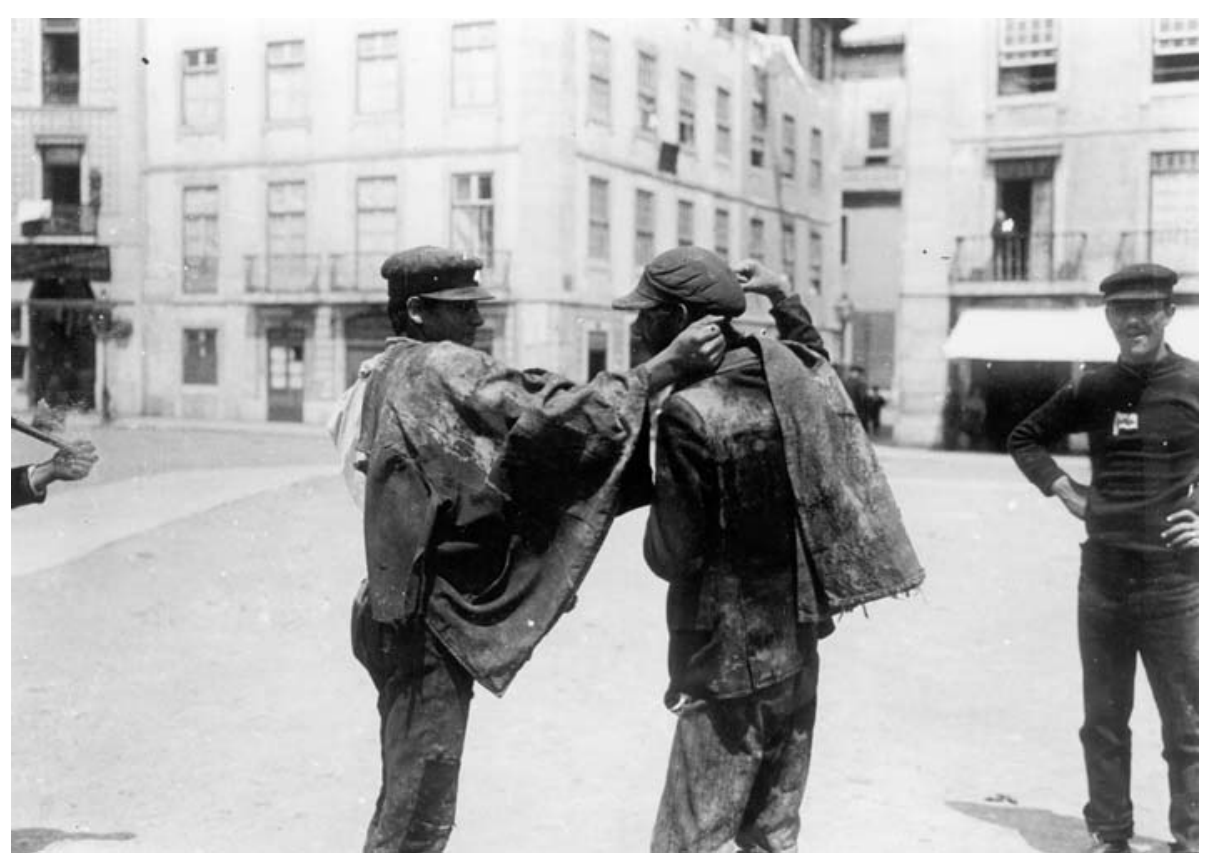

Figura 17 - Joshua Benoliel. Limpadores de chaminés, 1906-1918, gelatina a partir de negativo de vidro. Acervo do Arquivo Fotográfico da Câmara Municipal de Lisboa, Lisboa.

encontravam espaço entre uma tarefa e outra para brincadeiras e alguma descontração.

Conhecidos como aguadeiros, os galegos surgiram com a necessidade de abastecimento de água em Lisboa. Vindos de Tuy, região da Galiza, estes homens carregavam sobre os ombros a água dos chafarizes e fontes para o abastecimento das casas. Vinham de longe e permaneciam em pontos estratégicos da cidade, "fazendo esquina" (como se dizia), aguardando um trabalho aqui e acolá. Benoliel os mostra em diferentes clichês, fazendo saber que o trabalho era sempre feito em grupo. Homens jovens e fortes, mostravam-se dispostos a qualquer trabalho (Figura 18). Em diferentes imagens, são flagrados por Benoliel, que os mostra transportando desde barris com água até pianos, tudo o que uma casa pudesse conter. Acostumados ao peso de seu trabalho, eram também conhecidos como aqueles que conseguiam "equilibrar o recheio de uma casa em duas travessas sobre suportes de rodas", sendo muito utilizados para fazer mudanças. Trabalhavam mais nos fins de semestre, quando a renovação do aluguel inviabilizava a permanência do inquilino, que saía pela cidade à procura de um outro quarto para alugar. Também eram eles que auxiliavam os habitantes da ribeira durante as enchentes de inverno, esvaziando suas casas invadidas pelas águas.

Benoliel registra diferentes momentos desta forma de trabalho como, por exemplo, as dificuldades de transportar mobílias por portas estreitas em casas de andares pelas ruas de Lisboa (Figuras 19 e 20). 


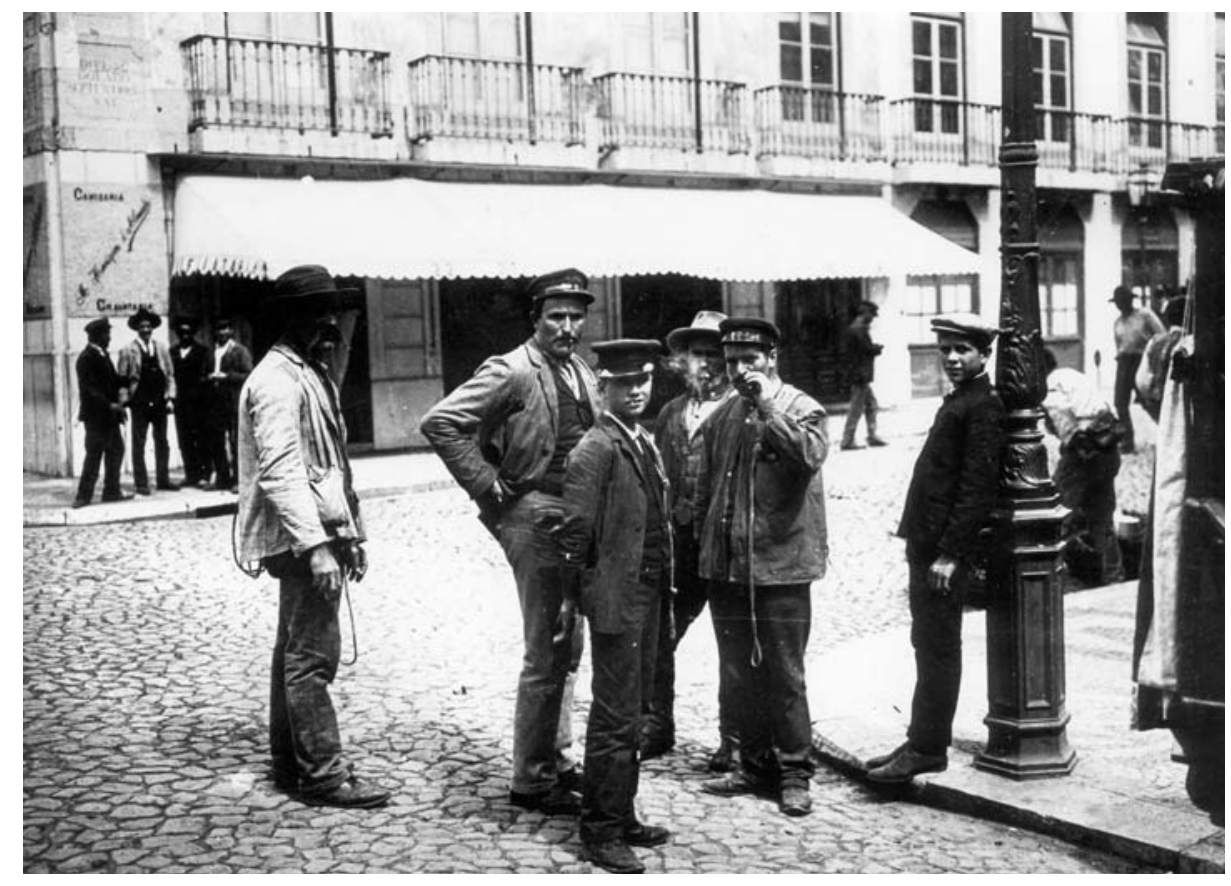

Figura 18 - Joshua Benoliel. Moços e frete, 1906-1918, gelatina a partir de negativo de vidro. Acervo do Arquivo Fotográfico da Câmara Municipal de Lisboa, Lisboa.

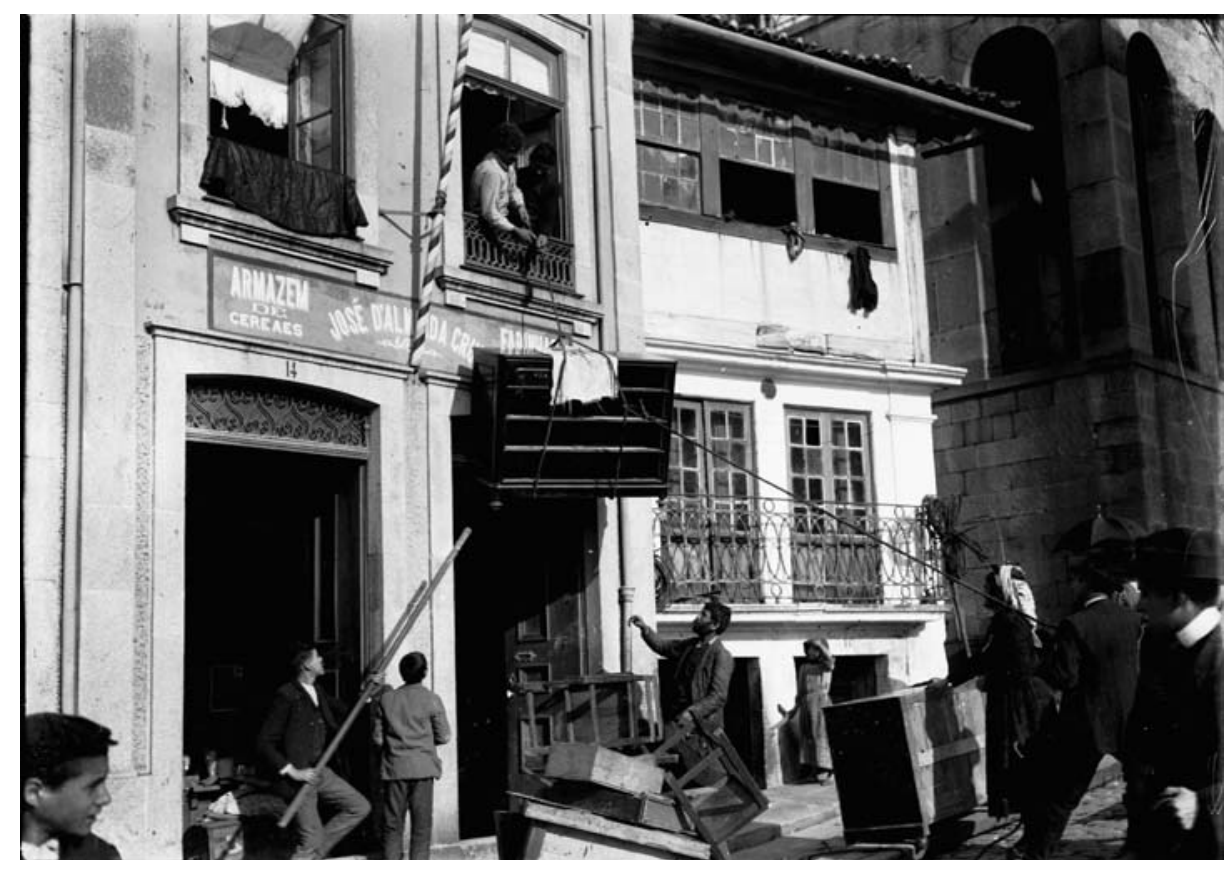

Figura 19 - Joshua Benoliel. Dia de mudança, 1906-1918, gelatina a partir de negativo de vidro. Acervo do Arquivo de Fotografia de Lisboa, Lisboa. 


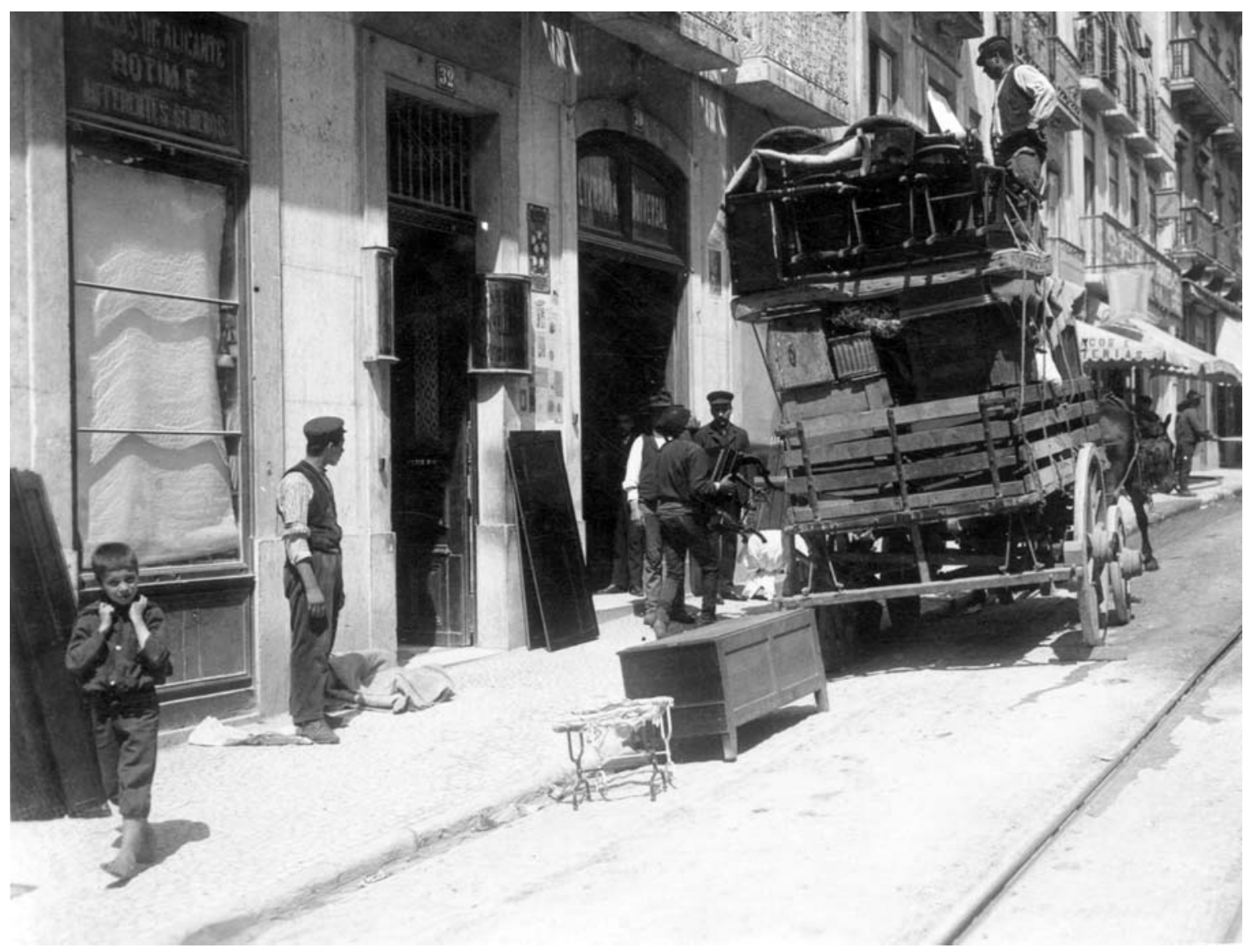

Figura 20 - Joshua Benoliel. Dia de mudança, 1906-1918, gelatina a partir de negativo de vidro. Acervo do Arquivo Fotográfico da Câmara Municipal de Lisboa, Lisboa.

32.Aluguéis

33. Ilustração Portugueza, Lisboa, 9 set. 1907.
Sobre o problema das mudanças na cidade de Lisboa em função do aumento de rendas ${ }^{32}$, a llustração Portuguesa escreve:

Quando chega junho, o lisboeta que se muda de casa tem sobre si um encargo mais pesado que o mundo: - é o de arranjar carroças ou gallegos que the transportem a mobilia de um extremo ao outro da cidade. Dizia um ratão que mais vale um incendio do que quatro mudanças seguidas. É possivel que seja verdade. [...] Que Deus nos livre de mudanças e de moços de fretes, que são uma praga pior que a dos gafanhotos e que nos levam, n'este momento critico - o couro e o cabelo! ${ }^{33}$

Este trabalho de esquina revelava a existência de um mercado bastante informal, onde todas as transações eram feitas na hora, de acordo com a cara do freguês, levando alguns ao horror no momento de efetuar seus pagamentos. A dinâmica de prestação de serviços em troca de pagamento também deixava claro o menosprezo por determinadas atividades que a população em geral recusava-se a fazer, levando tais galegos a cobrar o preço que quisessem. Este 


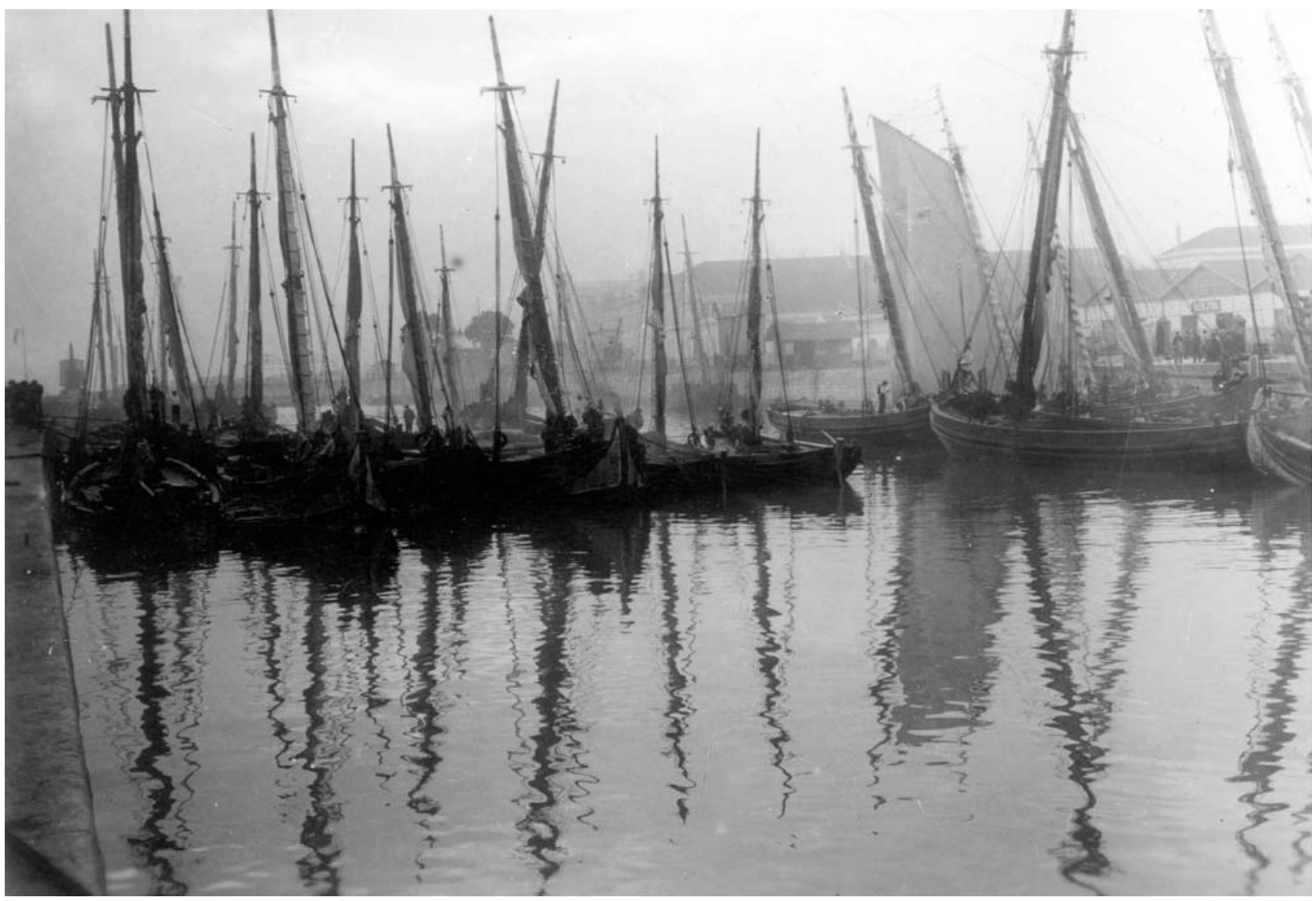

Figura 21 - Joshua Benoliel. Fragatas em dia de greve, 1906-1918, gelatina a partir de negativo de vidro. Acervo do Arquivo Fotográfico da Câmara Municipal de Lisboa, Lisboa.

fato acontecia não apenas com as mudanças, mas também com o transporte de água pelos aguadeiros.

Do trabalho carregado nos ombros pelas ruas e ruelas, os galegos, junto com outros personagens urbanos, iam trazendo movimento e vida para diferentes espaços. Ao lado dos fragateiros ${ }^{34}$, ajudavam no abastecimento da cidade e no escoamento de tudo o que a cidade dependia e produzia. Nos registros de Benoliel, encontramos estas embarcações em um dia de greve, onde a paralisação das embarcações significava ausência de trabalho, prejuízos econômicos, ao mesmo tempo em que flagra um belo espetáculo de harmonia e tons... (Figura 21). Também os fragateiros eram acostumados ao trabalho duro de transportar com o próprio corpo o que a cidade necessitava. Benoliel os registra em ação e fornece clichês em que o movimento e o ritmo do trabalho de transporte de carvão, madeiras ou peixe deixam transparecer o trabalho duro realizado por homens e por jovens trabalhadores. É o caso da Figura 22, sobre a descarga de carvão no cais do Sodré; ou sua manipulação em fábricas, como
34.Tripulante das fragatas do Tejo.As fragatas eram barcaças solidamente construídas, utilizadas especialmente para a descarga de navios. 


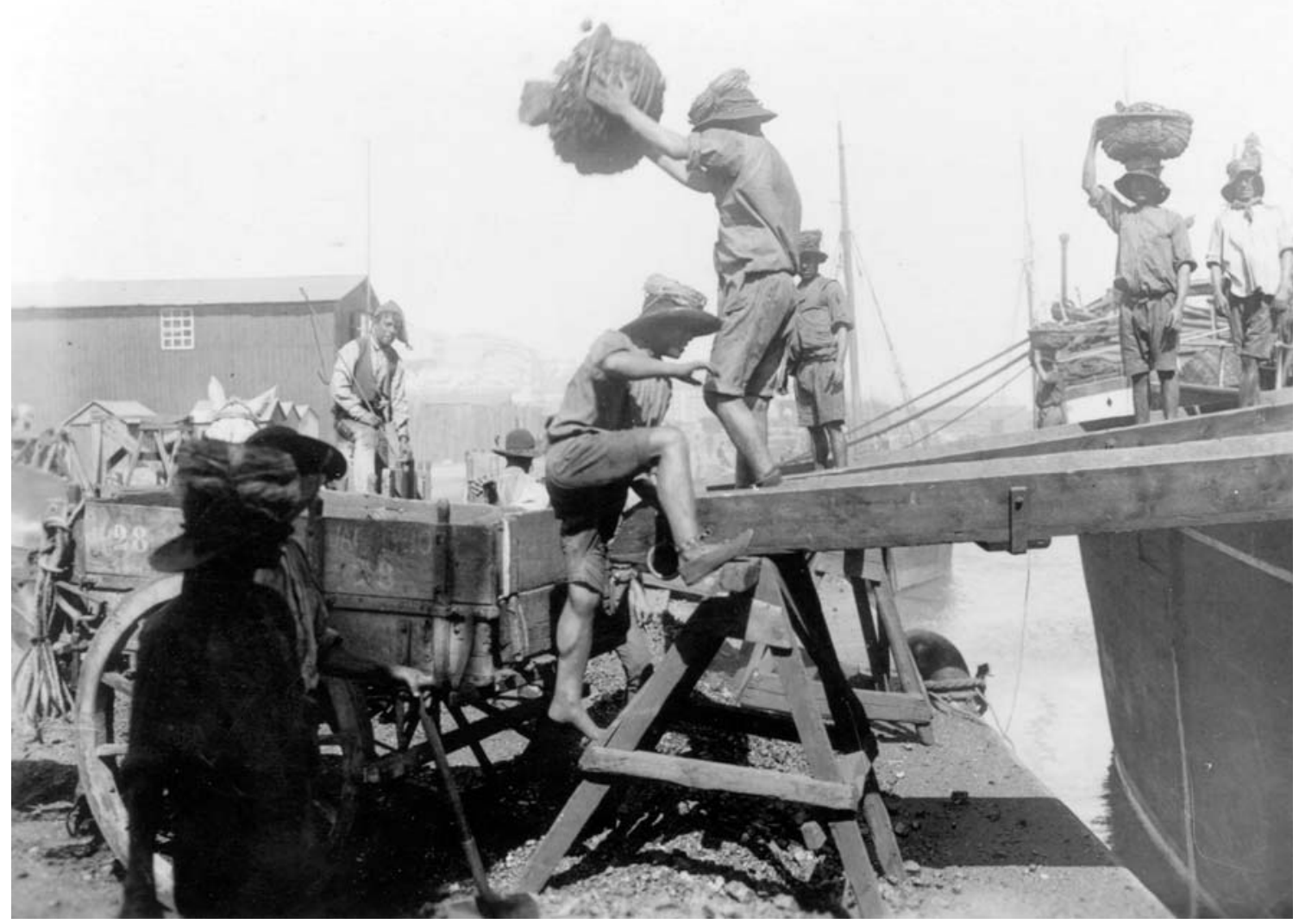

Figura 22 - Joshua Benoliel. Descarga de carvão no Cais do Sodré, 1906-1918, gelatina a partir de negativo de vidro. Acervo do Arquivo Fotográfico da Câmara Municipal de Lisboa, Lisboa.

35. Idem. Lei $\mathrm{n}^{\mathrm{0}} 1398$, de 23 de março de 1911, p. 32. Coleção Actos e Decretos do Município de S. Paulo. na Figura 23, onde o trabalho duro é desenvolvido por mãos infantis; ou na Figura 24, em que os fragateiros trabalham na descarga do peixe no cais. Estes trabalhos não escolhiam idade, e muitas vezes nem mesmo o sexo, já que era comum o trabalho de mulheres na carga e descarga de diferentes produtos no porto de Lisboa. Em relação à idade, nota-se a juventude de muitos, alguns ainda quase crianças, mas que já sabiam o peso que o trabalho podia ter.

Nas ruas de São Paulo, uma categoria muito semelhante de trabalhador eram os chamados carregadores, que chegaram a ter sua profissão regulamentada, em março de 1911 , por lei exigindo que fossem maiores de 18 anos. As licenças concedidas pela prefeitura do município seriam cassadas em caso de embriaguez habitual ou eventual "crimes contra a propriedade". Com respeito a esta última infração, não há maiores detalhes, mas parece que, por estarem envolvidos no carregamento de objetos particulares, a lei protegia proprietários em caso de se sentirem lesados de alguma forma. A embriaguez parece ser corrente. Todavia, só seriam cassados os que fizessem isso habitualmente, indicando que eventuais casos de embriaguez pareciam ocorrer com certa freqüência ${ }^{35}$. 


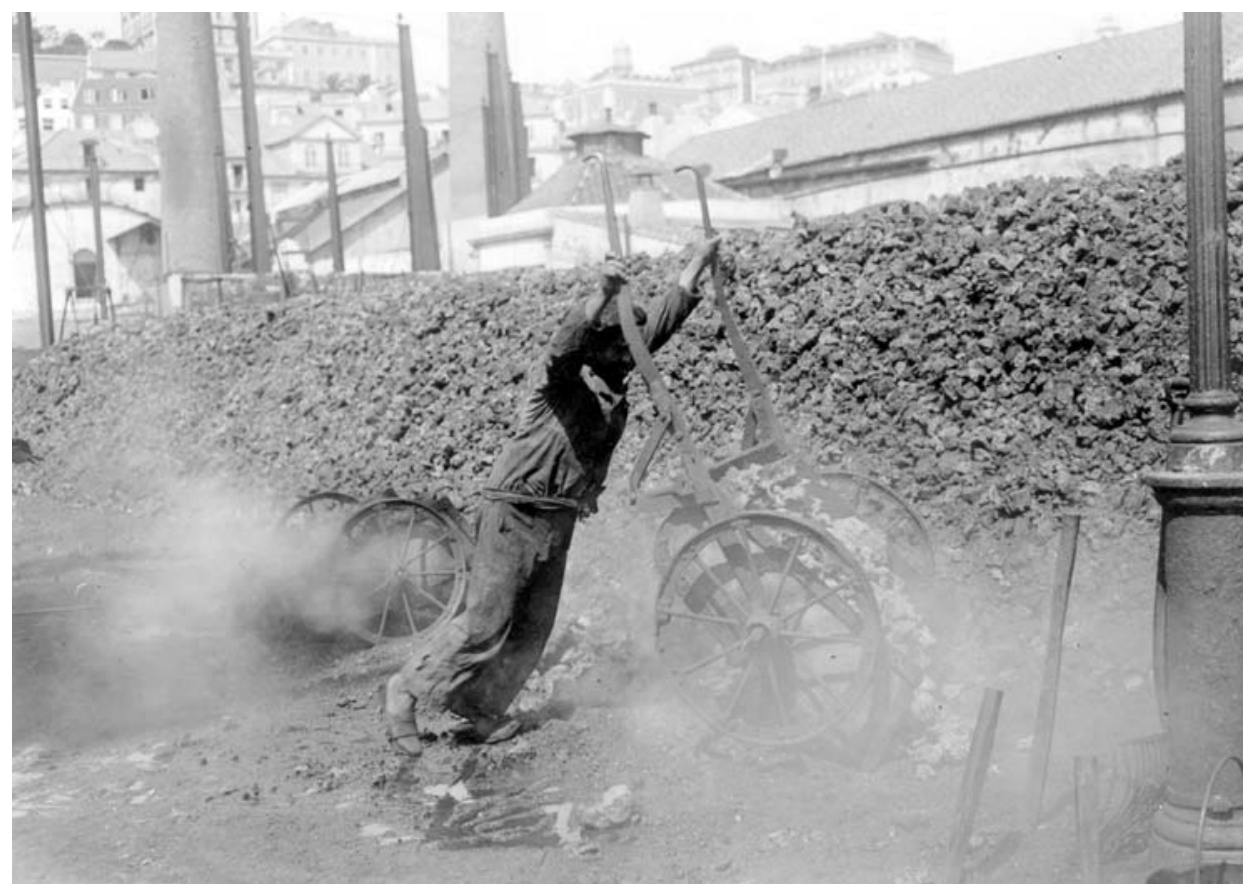

Figura 23 - Joshua Benoliel. Trabalho com carvão, s.d., gelatina a partir de negativo de vidro. Acervo do Arquivo Fotográfico da Câmara Municipal de Lisboa, Lisboa.

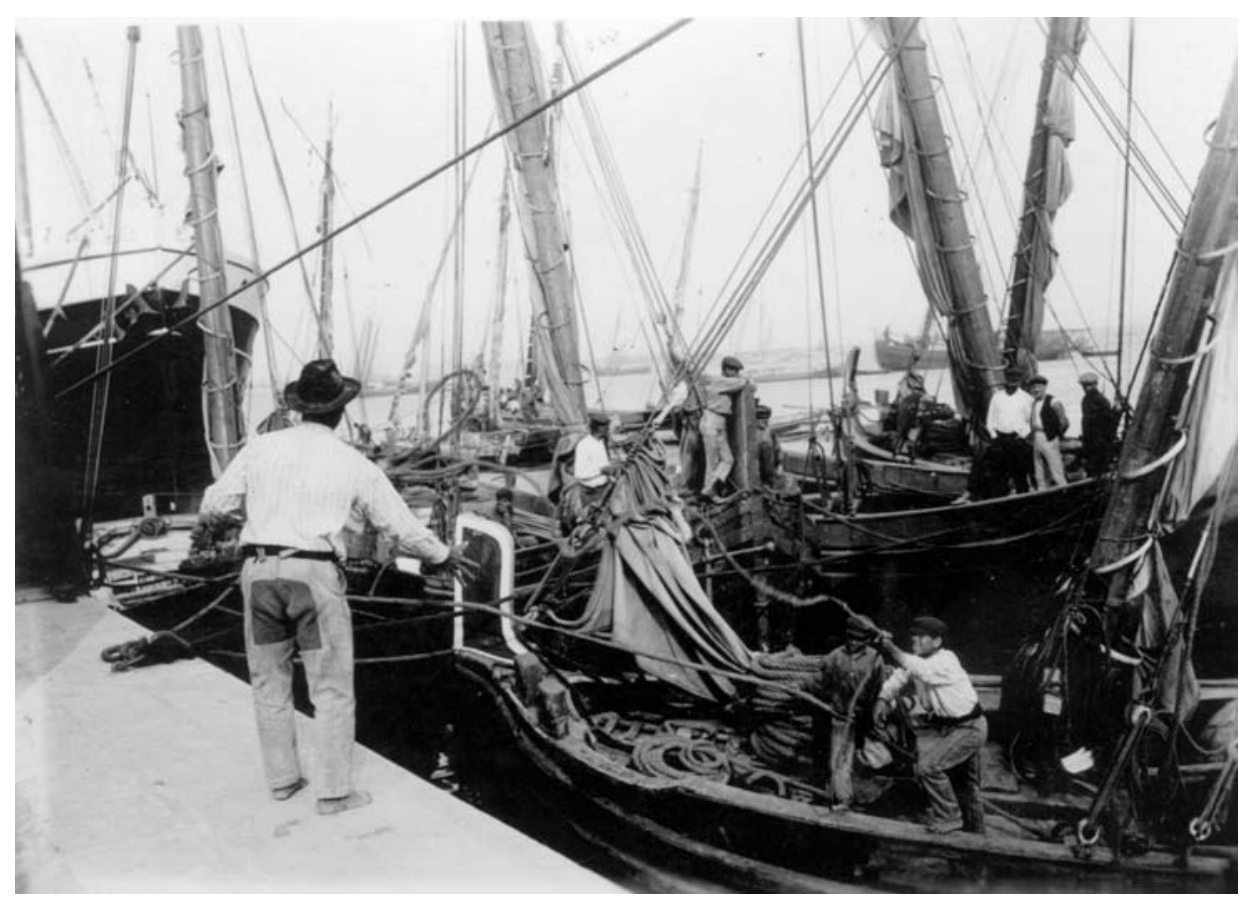

Figura 24 - Joshua Benoliel. Fragateiros na descarga do peixe, 1906-1918, gelatina a partir de negativo de vidro. Acervo do Arquivo Fotográfico da Câmara Municipal de Lisboa, Lisboa. 
36. Termo que serve para designar o camponês ou aldeão que vive nos arredores de Lisboa, sempre com uma conotação de rusticidade. É também um termo sinônimo de Moiro, originário de Salé. Sobre a origem do termo $s a$ loio, Marina Tavares explica: "A primeira população árabe instalada nos arredores de Lisboa beneficiara da tolerância do conquistador cristão. Depois, estendeu-se [...] pagando sempre o seu çalaio pelo pão cozido.[...] $\mathrm{O}$ estipulado çalaio acabou por degenerar em "çaloio" como designação étnica" (TAVARES, 1992, vol.3,p.91).
Em cestos sobre saias

Dos trabalhadores abordados por Benoliel, verifica-se que boa parte da força de trabalho encontrada nas ruas alfacinhas provinha, em sua maioria, do trabalho infantil e do trabalho de mulheres. A esse respeito, suas imagens adquirem muita força e vida a partir do momento que começam a retratar tais mulheres em ação. Vinham de longe, dos arredores de Lisboa e eram conhecidas como saloias ${ }^{36}$.

A produção saloia incluía, em especial, produtos hortifrutigranjeiros, como frutas, legumes, verduras, hortaliças, galinhas, perus, leite, azeitonas, azeite, ovos, queijos etc., que eram transportados em jumentos, sendo muito consumidos pela população urbana de Lisboa. Nesta produção saloia figuravam também outras delícias, como "o requeiião em cestinhos, os bolos de Belas, o pão de Melaças, as queijadas de Sintra, a marmelada de Odivelas, os vinhos de Bucelas ou de Colares". (DIAS, 1992, v. 3, p. 91).

Eram nas ruas, largos e praças que ofereciam seus produtos. Nas imagens de Joshua Benoliel, essas mulheres eram representadas sempre de forma alegre, dando uma idéia de movimento e ritmo. São os casos, por exemplo, das vendedoras de figos com seus cestos, após a descarga no cais da Ribeira Nova, ou da vendeira ambulante de galinhas (Figura 25). Esta última, com uma

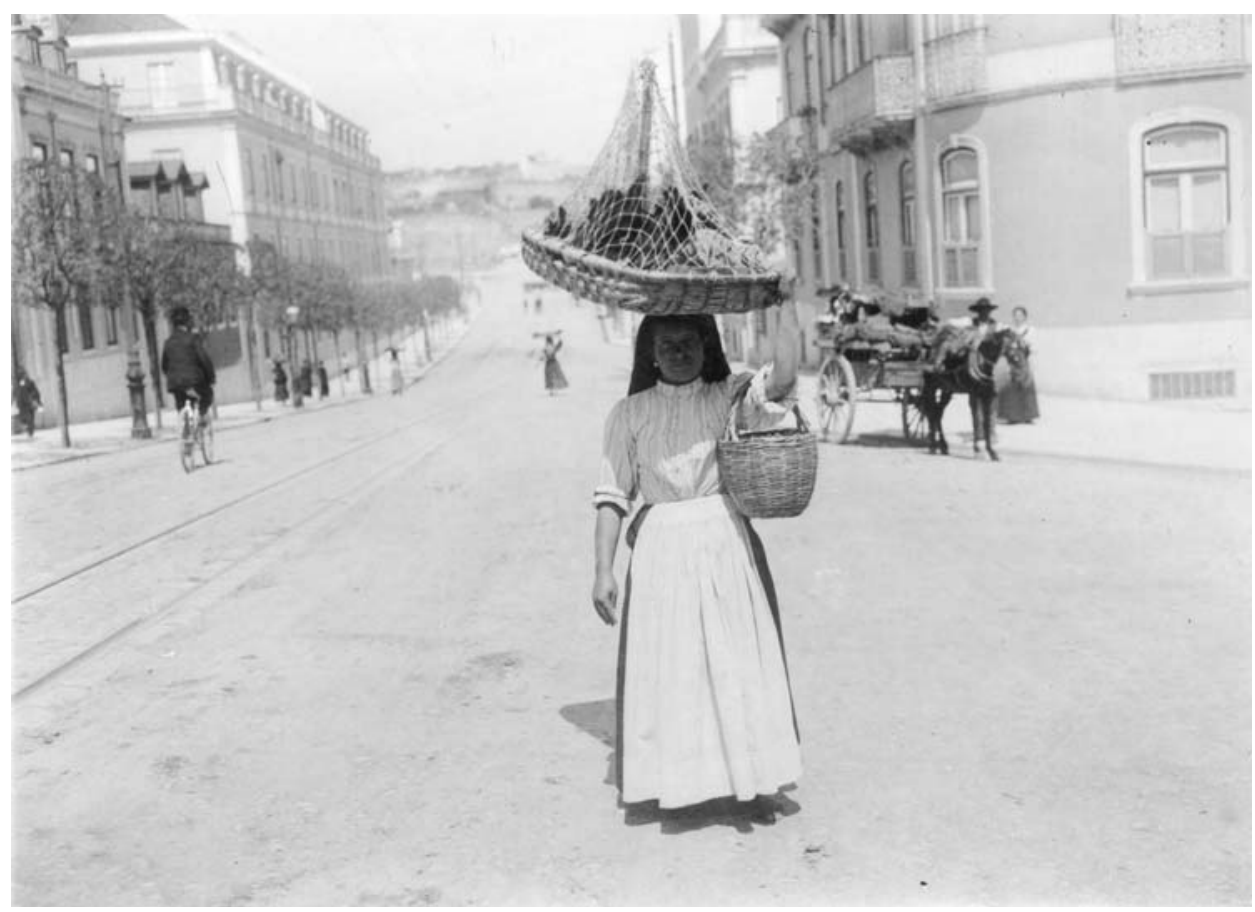

Figura 25 - Joshua Benoliel. Vendeira ambulante de aves, 1906-1918, gelatina a partir de negativo de vidro. Acervo do Arquivo Fotográfico da Câmara Municipal de Lisboa, Lisboa. 
característica interessante: ao invés de ter suas aves soltas, em grande número, roçando pelos pés - característica do modo como as saloias vendiam seus animais, esta os trazia presos à cabeça por uma capoeira ${ }^{37}$ armada sobre uma canastra $^{38}$, coberta com uma rede segura por uma estaca, nos braços um cesto provavelmente contendo ovos frescos. Vendidos aos poucos, não chamavam tanta atenção quando ela cruzava as ruas.

Além da venda desses produtos, uma imagem freqüente das mulheres saloias era a das lavadeiras. Responsáveis pela brancura das roupas dos alfacinhas, as saloias têm suas imagens sempre ligadas a imensas trouxas de roupas transportadas sobre as cabeças. Essas trabalhadoras desenvolviam seu trabalho nos lavadouros públicos municipais ou nas ribeiras existentes em torno da cidade e, em muitos casos, devido à distância, tinham de pernoitar no caminho entre o trabalho e sua casa, muitas com suas filhas pequenas, que também ajudavam na lida e, desde cedo, aprendiam aquela que seria a sua ocupação futura.

As imagens de Benoliel mostram com beleza essas mulheres e seus afazeres. Por exemplo, as lavadeiras no lavadouro público municipal (Figura 26), ou a Figura 27, que mostra a quantidade de trouxas aguardando para ser transportadas, com a saloia tendo ao seu lado uma menina que, como muitas outras, acompanhava a mãe nestas tarefas. A imagem, apesar de revelar o lado do trabalho feminino e infantil, trazia para a sua composição um outro universo

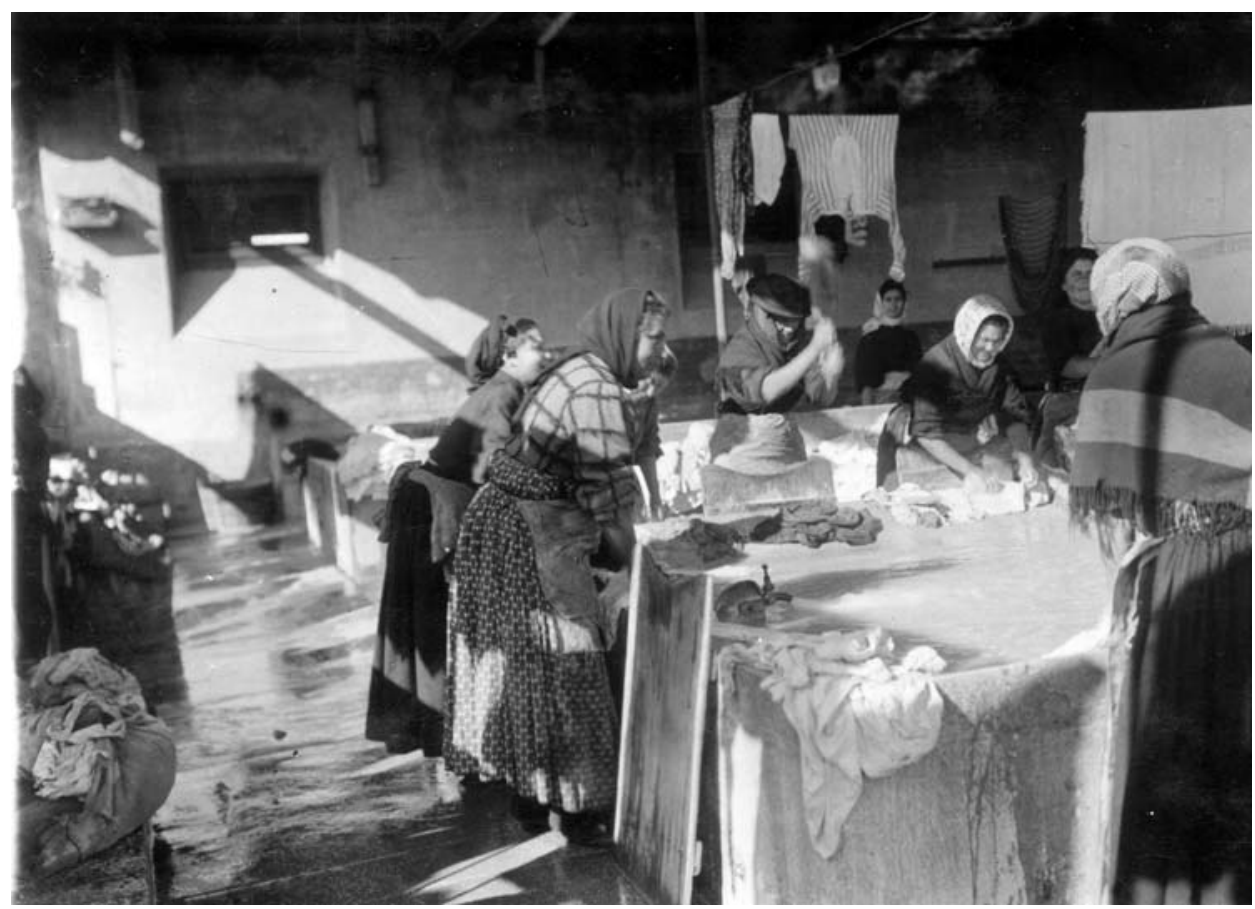

Figura 26 - Joshua Benoliel. Lavadouro Público Municipal, 1906-1918, gelatina a partir de negativo de vidro. Acervo do Arquivo Fotográfico da Câmara Municipal de Lisboa, Lisboa.
37. Cesto grande, gradeado, onde se guardavam e criavam capões ou outras aves.

38. Cesta larga e pouco alta. 


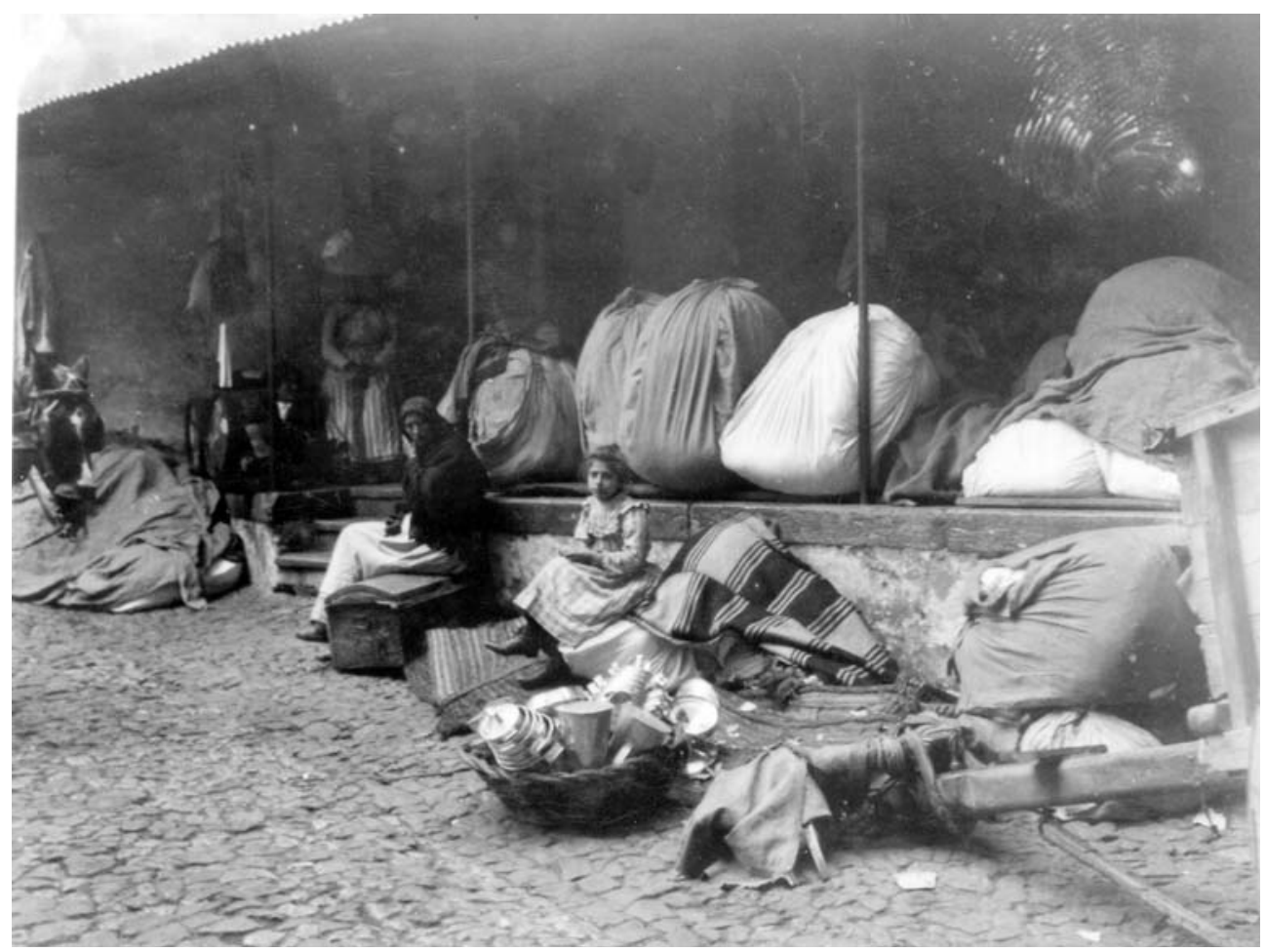

Figura 27 - Joshua Benoliel. Lavadeiras saloias, 1906-1918, gelatina a partir de negativo de vidro. Acervo do Arquivo Fotográfico da Câmara Municipal de Lisboa, Lisboa.

39. Vendedora ambulante de peixe. Segundo Marina Tavares, "A designação 'varina' abreviada de ovarina - abrange todas as mulheres oriundas da zona de Ílhavo, Aveiro, Murtosa e Ovar. Diz Pinho Leal, No Portugal Antigo $e$ Moderno, que os vareiros eram oriundo exclusivamente de Ovar ("vareiro", etmologicamente, de "vara" - percha para conduzir os barcos). [...] Físicamente, o varino reúne uma porção de atributos tidos como herança fenícia: elegância de gestos, altivez de porte, feições enérgicas, olhos invariavelmente escuros" (TAVARES, 1992, vol. 3, p. 57-58). de preocupação que era alvo de artigos na imprensa escrita. $\bigcirc$ receio é claramente exposto por um leitor, preocupado com a contaminação do leite e seu transporte pela cidade, que escreve ao jornal em matéria publicada em 21 de janeiro de 1913:

Ha carroças que no regresso de Lisboa não conduzem comida pôdre, mas sim roupa suja e as lavadeiras tudo amontoado e confundido na maior promiscuidade. Ora, essa roupa suja pode ter servido a tifosos, a tuberculosos, a doentes de todas as doenças contagiosas. Durante o trajeto, facil será operar-se uma sementeira nas bilhas, ainda sujas de leite.

hábito de aproveitamento do transporte de roupas com bilhas de leite estendeu-se pelo tempo, no espaço, e foi fartamente veiculado nos meios de comunicação, sendo objeto de inúmeras críticas por parte de especialistas sanitários e consumidores em geral.

Algumas mulheres ganhavam, nas imagens de Benoliel, um sentido muito especial e passavam a significar a própria Lisboa. Era o caso, por exemplo, das varinas ${ }^{39}$ (Figura 28). Sempre muito faceiras, com seus chapéus de abas, saias rodadas, mãos à cintura e um andar quase sempre de dançarina, tornavamse alvo de inúmeros clichês. Figura símbolo de uma cidade que tem sua face voltada para o mar, as varinas personificavam o alimento que vinha do mar, 


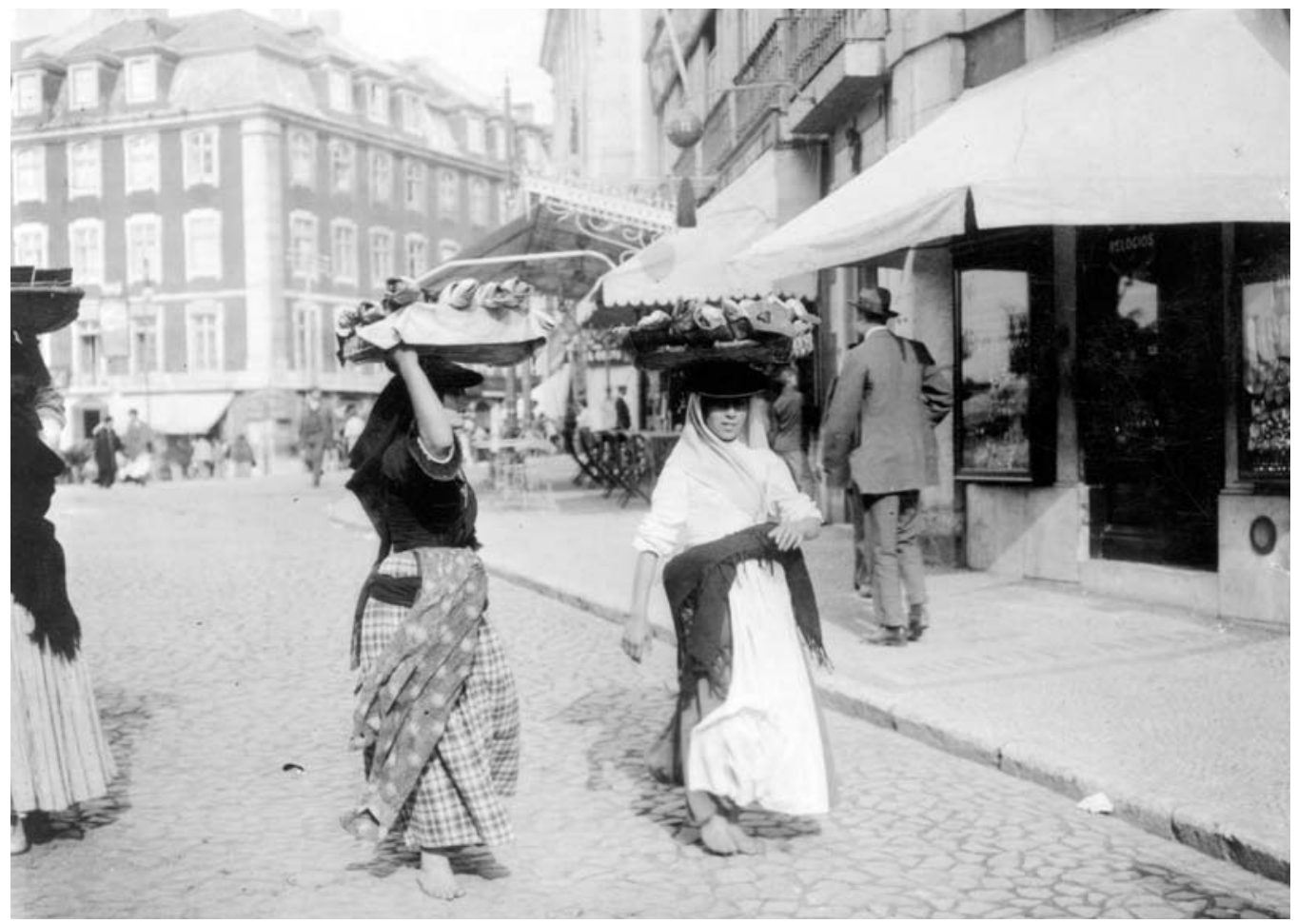

Figura 28 - Joshua Benoliel. Varinas na venda do peixe, 1906-1918, gelatina a partir de negativo de vidro. Acervo do Arquivo Fotográfico da Câmara Municipal de Lisboa, Lisboa.

metaforicamente considerado como sendo o maior e mais antigo mercado da humanidade. Nas palavras do articulista da llustração Portugueza: "O mar é o melhor, mais fecundo e mais economico mercado da humanidade" 40 .

Sobre estas mulheres que viviam do trabalho com o comércio do peixe, o mesmo articulista as descreve como "a menear-se como um rebolo, de formas opulentas, rosto appetitoso e pregão constante, até o Vatel de carapuço e avental branco que a prepara, origina múltiplos e rendosos comércios e industriais, que vivem exclusivamente da sua benfica acção" ${ }^{\prime 1}$. Adotada como figura símbolo de Lisboa e, em determinados contextos, também de Portugal, a varina podia ser considerada "uma singular figura do nosso meio trabalhador. É brava, incansavel, uma verdadeira mourinha de labuta sendo, ao mesmo tempo, quasi sempre encantadora [...]. É a varina das mais belas mulheres da nossa terra, onde as há tão formosas" 42 (Figura 29).

Em todos os registros de Benoliel, a figura feminina é uma constante e, através de seu olhar, é-se capaz de ver por onde o trabalho feminino andava. Em seus clichês, há uma valorização do trabalho feminino, mostrado sem preconceito e com o movimento próprio das ruas. Talvez, simplesmente, por ser este um trabalho realizado com naturalidade e em quantidade.
40. A ALIMENTAÇÃO que o mar nos pode dar. Ilustração Portugueza, Lisboa, n.188, 27 set. 1909.

41. Idem.

42. COSTUMES Portugueses, Ilustração Portugueza, Lisboa, n. 371, 31 mar.1913. 


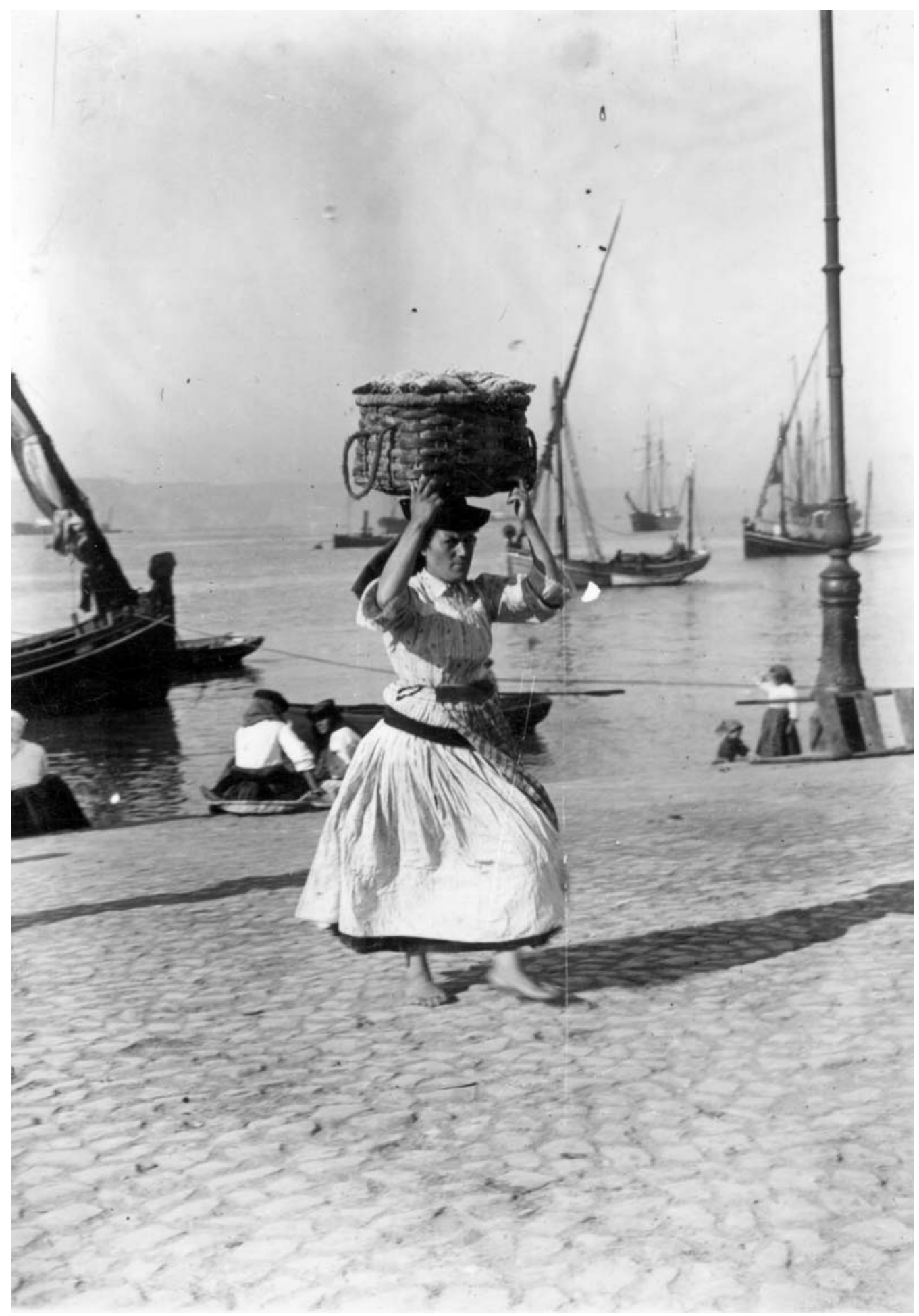

Figura 29 - Joshua Benoliel. Varina, 1906-1918, gelatina a partir de negativo de vidro. Acervo do Arquivo Fotográfico da Câmara Municipal de Lisboa, Lisboa. 
Com um número tão expressivo de mercadores ambulantes, não seria de se estranhar que o tema da circulação fosse, cada vez mais, tomado em consideração pelas autoridades administrativas, e que sempre se discutisse a necessidade de normalizar os espaços de uso público. A cidade, no olhar de Paula Souza, é constituída por espaços que distribuem funções e, neste sentido, mostra-se hierarquizante e bem definida.

Para São Paulo, suas imagens quase sempre excluíam o fluxo intenso de pessoas, e não parecia ser priorizado o elemento humano, mas sim a ordem e limpeza das edificações, vistas como paisagem. A cidade analisada pelo olhar sanitarista tem características peculiares e quase sempre está livre do burburinho de ambulantes. Em muitos casos, os registros fotográficos têm a ausência do elemento humano: elemento perturbador e poluidor da harmonia de formas...

Apesar disso, é interessante verificar a sua preferência pelas ruas do triângulo central, os jardins de arquitetura eclética do Museu Paulista, além das principais edificações consideradas modernas, como o Edifício Martinelli, ainda em construção, ou o Teatro Municipal. As ruas do triângulo central talvez tenham sua preferência por serem elas a rota do comércio e das atividades ligadas à prestação de serviço, enquanto, por exemplo, a avenida São João, avenida Paulista (Figura 30) aparecem como verdadeiros ícones de modernidade e da expansão da maior cidade do país.

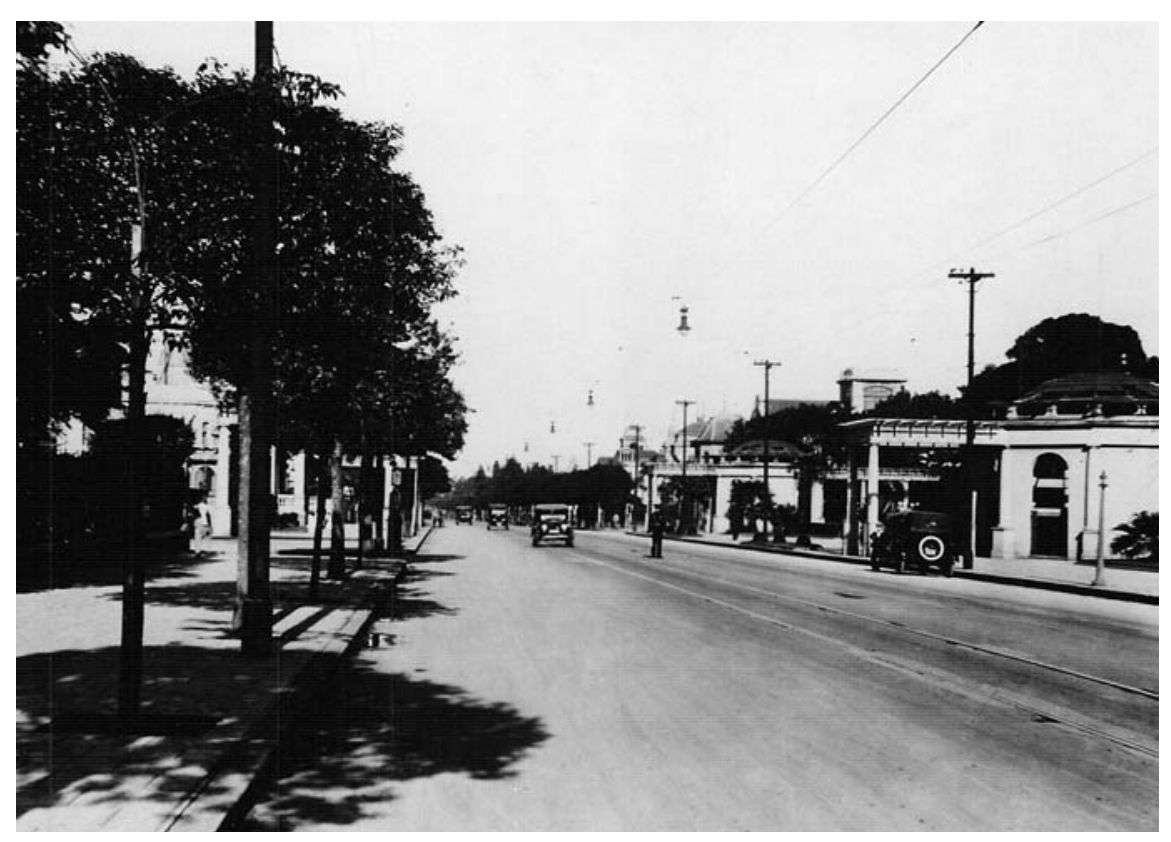

Figura 30 - Geraldo Horácio de Paula Souza. Av. Paulista, 1919-1925, gelatina a partir de Kodak Graflex Auto 4"x 5" Banoh x Lomb. TESSAR, f.45. Acervo da Biblioteca Faculdade de Arquitetura e Urbanismo da USP, São Paulo. Reprodução do Laboratório da FAUUSP. 
Ganham também interesse as edificações e as construções de grandes pavimentos ou áreas que congregavam grande número de pessoas, como fábricas, hotéis, penitenciária e outros locais de aglomeração humana (Figuras 31 e 32).

A cidade do sanitarista constitui-se de prédios, ruas e praças vazias, em oposição aos espaços sujos da multidão: as pessoas só aparecem em suas fotos sobre cortiços, focos infecciosos, ou no mercado municipal. A coleção divide-se didaticamente em espaços considerados objetos de organização sanitária - os cortiços, os mercados, os hospícios etc. - e, por contraste, passava para aqueles espaços que, na visão sanitarista, têm a solução para os problemas sociais encontrados na cidade: os destinados à educação, saúde e disciplina, personificados por escolas, prisões, hospitais, quartéis, praças e meios de transporte, entre outros.

Para nosso sanitarista, duas eram as ruas: aquelas estreitas e carregadas de vício e imoralidade, habitadas por mendigos, malandros, doentes

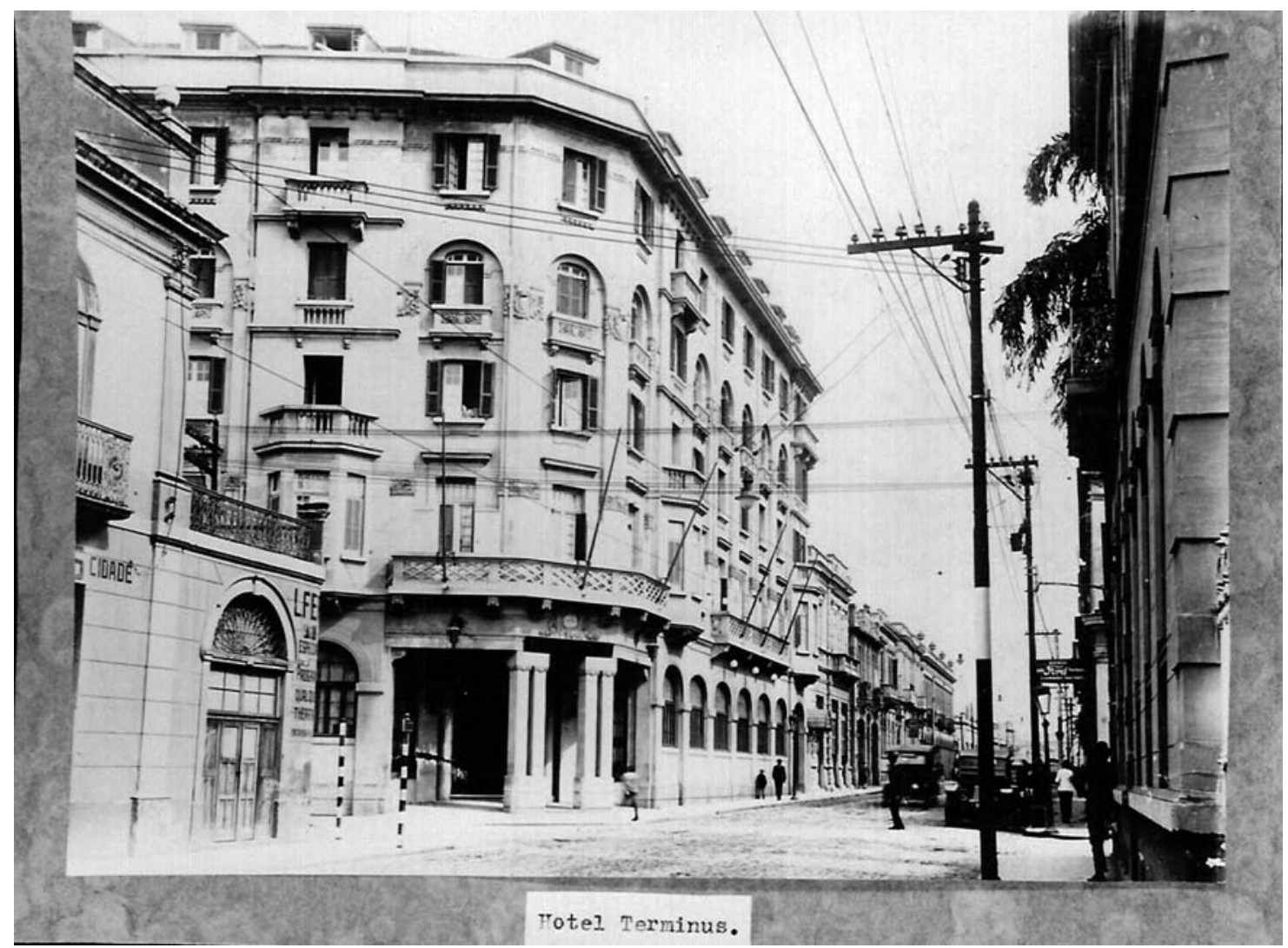

Figura 31 - Geraldo Horácio de Paula Souza. Vista externa do Hotel Terminus, 1919-1925, gelatina a partir de Kodak Graflex Auto 4"x 5" Banoh x Lomb. TESSAR, f.45. Acervo da Biblioteca Faculdade de Arquitetura e Urbanismo da USP, São Paulo. Reprodução do Laboratório da FAUUSP. 
e outros marginais, localizadas nas periferias do centro da capital e identificadas, principalmente, e com os bairros operários, em oposição àquelas por onde passa a vida sã e cultural, identificadas pelas ruas de comércio elegante ou as que conduziam aos cinemas, teatros e parques da cidade.

Os espaços destinados ao lazer estavam normalmente nos espaços públicos, mas de convívio restrito, como era o caso dos teatros, cinemas e cassinos. As praças e parques escolhidos como motivo de registro eram, em sua maioria, os que denotavam um projeto urbanístico claro, indicando um vivo interesse nas intervenções efetuadas na cidade.

Os espaços registrados fotograficamente eram segmentados e são atentamente mostrados ao olhar perscrutador: a cidade passa a ser considerada como merecedora de estudo e análise especializada. $\bigcirc$ sanitarista a disseca e fragmenta, na esperança de melhor compreendê-la e mostrá-la ao olhar estrangeiro - entendido aqui não apenas como aquele que não reside na cidade, mas também aquele que não a conhece por não ter o olhar especialista.

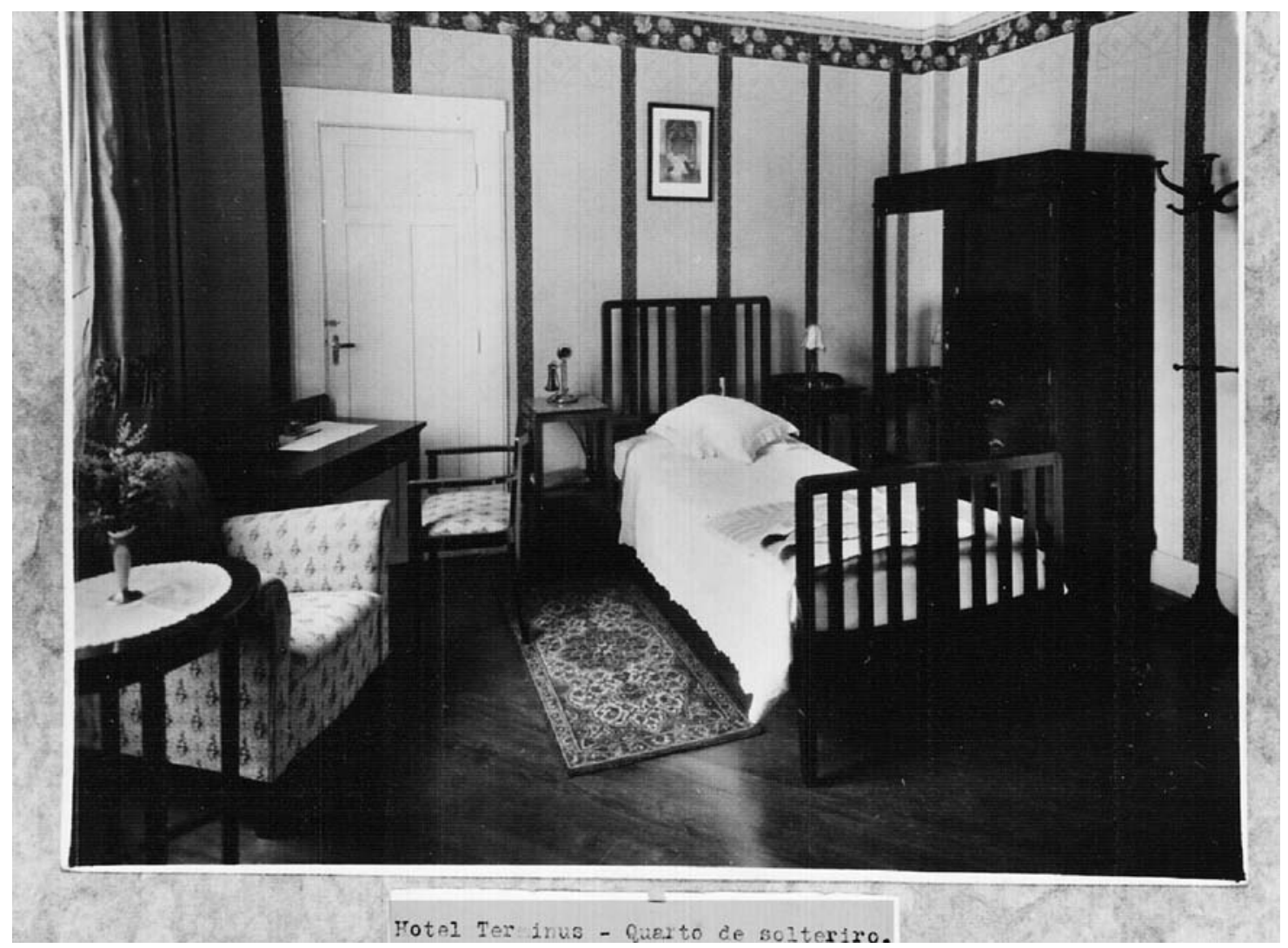

Figura 32 - Geraldo Horácio de Paula Souza. Vista interior de um quarto de solteiro do Hotel Terminus, 1919 1925, gelatina a partir de Kodak Graflex Auto 4"x 5" Banoh x Lomb. TESSAR, f.45. Acervo da Biblioteca Faculdade de Arquitetura e Urbanismo da USP, São Paulo. Reprodução do Laboratório da FAUUSP. 
Neste ponto, não se deve esquecer os equipamentos desta dissecação, dentre os quais está a própria fotografia. Recortando e selecionando espaços a serem detidamente examinados, o olhar fotográfico cumpre a função de relatar e propor. Relata as diferentes condições de vida encontradas no tecido social e propõe soluções que estão diretamente relacionadas à atividade e ao ofício de médico sanitarista. Deste modo, o conjunto de imagens se coloca como um documentário sobre a cidade: seu lixo, suas águas, sua circulação, seus personagens, suas construções etc.

Seus registros fotográficos refletem de forma incontestável um método de trabalho: os espaços urbanos tornam-se imensos laboratórios de estudo de patologias sociais que interferem diretamente na saúde física, mental e emocional, devendo, portanto, ser conhecidos para, em seguida, poderem ser combatidos.

Os registros, como ocorre com outras séries deste fotógrafo, revelam fortes preocupações sanitárias, documentadas através do registro fotográfico que, provavelmente, serviria de prova para seus estudos sobre a aplicação de leis sanitárias ao espaço urbano.

Dos espaços tidos como de reclusão/educação, Paula Souza opta por alguns registros muito pontuais. Lá está, por exemplo, a mulher que, atrás da reclusão de um cárcere, acena com os braços aos que por ela passam (Figura 331. $\bigcirc$ registro faz pensar sobre duas formas de reclusão: uma física, que é

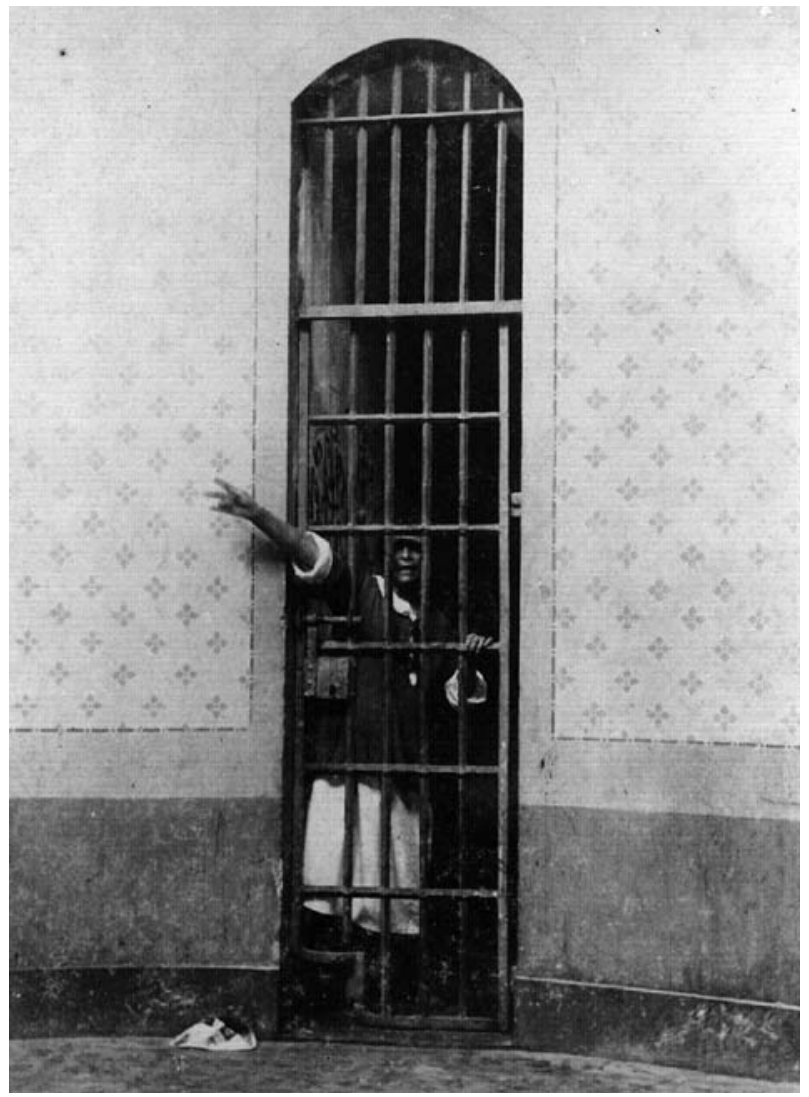

Figura 33 - Geraldo Horácio de Paula Souza. Mulher reclusa, 1919-1925, gelatina a partir de Kodak Graflex Auto 4"x 5" Banoh x Lomb. TESSAR, f.45. Acervo da Biblioteca Faculdade de Arquitetura e Urbanismo da USP, São Paulo. Reprodução do Laboratório da FAUUSP. 
dada pelo confinamento atrás de grades que tiram e tolhem os movimentos, reservando apenas a possibilidade do aceno, outra é a idéia da exclusão social e do abandono, vividos provavelmente pela doença mental ou física ${ }^{43}$. Defensor da reclusão em casos de doença, Paula Souza justificava que tal necessidade se impunha como meio de evitar a propagação de males à sociedade considerada sã.

Um outro exemplo são os detentos que revolvem o lixo produzido pela Penitenciária do Estado de São Paulo, localizada no bairro do Carandiru (Figura 34). Num único registro, são tratados dois dos grandes problemas da cidade: o destino e o manejo do lixo, e a reclusão como instrumento de reeducação e reintegração do criminoso na sociedade.

Sob este último aspecto, o princípio da chamada profilaxia social via na disciplina e no trabalho - organizado, ordenado e limpo - o resgate do indivíduo para o meio social| ${ }^{44}$ (Figura 35). Tais objetivos ficam claros quando se analisa os regulamentos para o trabalho que era desenvolvido por tais detentos.
43. Era habitual A reclusão por hanseníase e este pode ser o caso.

44.A questão do tratamento dispensado ao recluso, no caso português, é interessante, já que eles não tinham nem mesmo o direito de comparecer publicamente com seus rostos descobertos. Em um de seus clichês, Benoliel registra a "queda do capuz" nas penitenciárias de Portugal.Trata-se da Figura 35, que mostra quando o capuz é abolido e os presos passam a ter autorização de mostrar seu rosto e ter visitas semanais aos domingos; mas, mesmo com tal permissão, alguns preferem manter o uso do capuz, em sinal de arrependimento e vergonha.

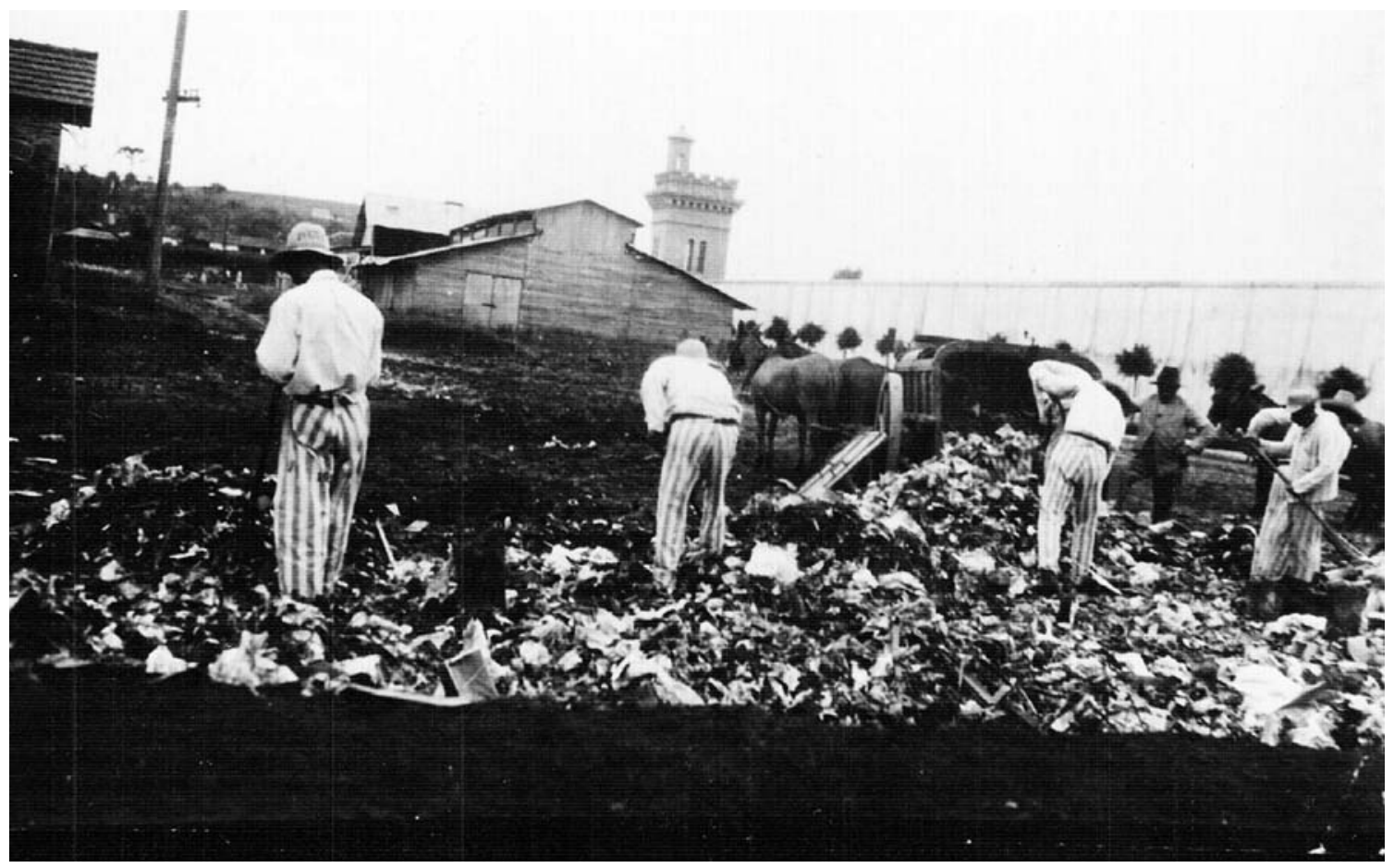

Figura 34 - Geraldo Horácio de Paula Souza. Presidiários na Penitenciária do Carandiru em São Paulo, 1919 1925, gelatina a partir de Kodak Graflex Auto 4"x 5" Banoh x Lomb. TESSAR, f.45. Acervo da Biblioteca Faculdade de Arquitetura e Urbanismo da USP, São Paulo. Reprodução do Laboratório da FAUUSP. 


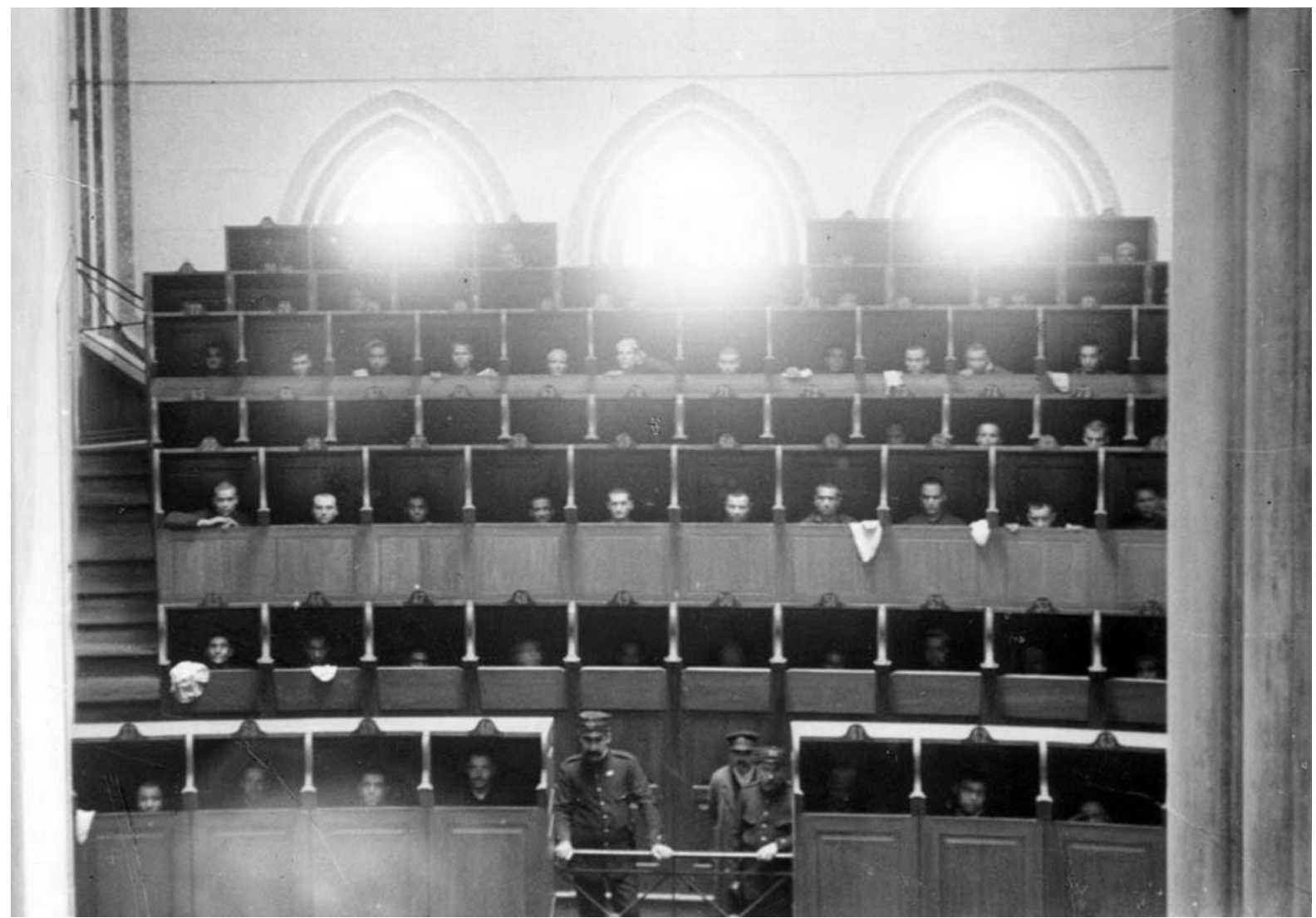

Figura 35 - Joshua Benoliel. A queda do capuz nas penitenciárias portuguesas, 1906-1918, gelatina a partir de negativo de vidro. Acervo do Arquivo Fotográfico da Câmara Municipal de Lisboa, Lisboa.

Olhares ilustrados

45. No período anterior, e principalmente no posterior, à implantação da República portuguesa, houve diferentes greves em vários setores da sociedade. Elas mobilizavam trabalhadores, em sua maioria descontentes com suas condições de vida e de salário. Em virtude disso, os clichês produzidos por Benoliel eram fartos e integravam com regularidade as páginas da imprensa diária do jornal $O$ Século e da revista Ilustração Portugue$z a$, e por si só merecem uma análise à parte.
Diferindo de Paula Souza, Joshua Benoliel ocupa-se de todos os elementos excluídos por outros fotógrafos. Observa detidamente o movimento das ruas e opta por registrar as formas de ocupação e circulação do espaço urbano. Suas imagens incluem manifestações, a favor da Monarquia, dos estudantes de Coimbra que se dirigiam a Lisboa; ou aquelas das greves de fragateiros (Figura 36); de motorneiros, ferroviários, de caixeiros, de corticeiros ${ }^{45}$, entre outras. São imagens em que a multidão não é, de forma alguma, ignorada, ao contrário, ocupa posição central, sem contudo excluir os elementos arquitetônicos, facilitando com isso sua identificação num plano mais geral. São vistas panorâmicas, com ampla valorização dos movimentos sociais. Talvez por isso sejam tão impactantes.

As praças, as ruas e os largos ganham força como espaços potencializadores de manifestações: propiciam o ajuntamento e favorecem a 


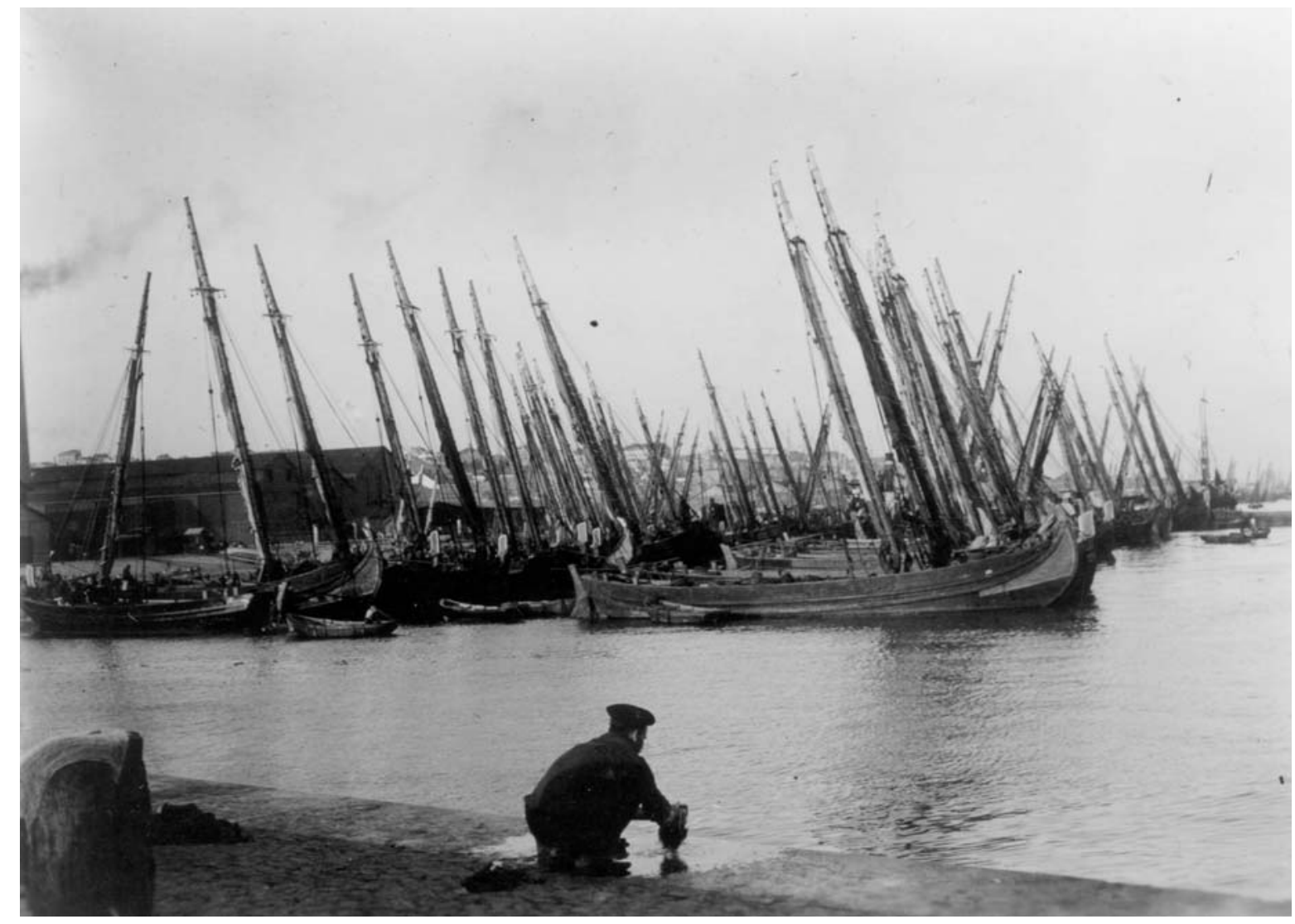

Figura 36 - Joshua Benoliel. Greve de fragateiros, 1906-1918, gelatina a partir de negativo de vidro. Acervo do Arquivo Fotográfico da Câmara Municipal de Lisboa, Lisboa.

visibilidade de grandes massas descontentes. E, neste sentido, as imagens de Benoliel são dotadas de muita força. Elas tratam da questão da multidão de uma forma bastante interessante. O fotógrafo preocupava-se com os movimentos sociais, com as diferentes formas de ajuntamento de sujeitos urbanos, especializando-se, num sentido estrito, em imagens de multidão. Enquanto seus companheiros normalmente fotografavam um aspecto muito pontual de qualquer acontecimento, nosso fotógrafo estava lá para buscar uma imagem mais abrangente que o usual. São imagens de grande força, mas nunca violentas. Sempre procurava mostrar as multidões homogêneas, unidas em torno de um objetivo comum.

As praças não eram ocupadas apenas para manifestações, podiam também ser usadas como ajuntamento para outros fins, como, por exemplo, as feiras e os passeios praticados no domingo à tarde. Eram nas ruas e nos parques da cidade que se fazia a 'avenida' (footing) e onde encontros e flertes eram amplamente realizados. Tal forma de lazer colocava-se em oposição ao ócio 
vagabundo e era praticada pela camada endinheirada da população, não possuindo, por isso, qualquer conotação de vadiagem ou desocupação.

No rastro de Rejeitos \& Dejetos

Fornecendo imagens, criando caminhos, a trajetória dos rejeitos e dejetos de uma cidade remete a diferentes aspectos de sua existência. Neste sentido, os tratamentos dispensados aos marginalizados urbanos, incluídos aí os mendigos, os presidiários, os loucos, os mortos e os desempregados, ocupam o centro das reflexões.

Além de motivo literário, personagens urbanos de meados do século XIX e princípios do XX, relacionados às tarefas que estivessem ligadas de perto aos rejeitos da cidade, constantemente eram tomados como referência de estudos sociológicos, médicos e políticos. Entre tantos, poderiam ser citados tripeiros, corticeiros, limpadores de fossas, trapeiros, presidiários, marinheiros, soldados e os deficientes mentais.

Do universo das sobras e rejeitos é que trapeiros e catadores retiravam sua subsistência e a de suas famílias, vendendo para empresas os produtos de suas buscas: papéis, trapos, ferros e outros materiais. Aparentemente tais trabalhadores tinham livre trânsito pela cidade e obtinham autorização de catar mesmo nos lixos domésticos e particulares. Tal atividade aos poucos se integrava de forma regular à rotina da cidade, criando na cadeia produtiva um sistema de informal de tarefas, ao mesmo tempo em que gerava, segundo especialistas, sérios problemas referentes à higiene domiciliária. $\bigcirc$ hábito de depositar detritos de forma domiciliária, para depois serem vendidos, parece ser mais comum do que se pensava.

O trapeiro, que realizava seus trabalhos de forma individual e ambulante pelas ruas da cidade, dificilmente conseguia reunir uma quantidade significativa de dinheiro. Era um trabalho que garantia apenas a sobrevivência quotidiana e, talvez por isso, encontramos um número grande de mulheres e crianças envolvidas nessa atividade, o que indica que dificilmente uma família inteira seria sustentada pelo trabalho de um único membro.

Diversos relatórios sobre o trabalho realizado nos depósitos espalhados pela cidade encontram-se recheados de registros fotográficos em que mulheres e crianças aparecem como principais personagens no trabalho de catagem e separação de trapos e outros resíduos.

O rastro de todos estes rejeitos era novamente a possibilidade de alimentar ainda mais um mercado produtor e consumidor que, cada vez mais, neles encontrava alternativas de vida e trabalho. A cidade, desta forma, mostrava seu lado autofágico... 
Nos caminhos dos rastros dos restos alfacinhas

Tal trabalho - desenvolvido nas ruas e autorizado, muitas vezes, pelas próprias donas-de-casa-podia ser igualmente encontrado nas ruas de Lisboa. Benoliel registra esse trabalhador no desempenho de suas atividades em pelo menos dois clichês: o primeiro é de um pequeno trapeiro à porta de uma casa à procura de trapos, papéis e outros objetos de interesse para comercializar. As pequenas mãos são ávidas, donas de uma curiosidade seletiva e nenhum outro cuidado com eventuais perigos de contágio. Ao seu lado, um saco guarda provavelmente os produtos do seu dia de trabalho (Figura 37).

No outro registro, o trapeiro tem sua imagem seqüestrada enquanto se distraía na decisão sobre o que incluir na coleta do seu trabalho. Como quase sempre ocorria, o catador realizava seu trabalho às portas das casas, nos vãos das escadas e em outros locais muito próximos das residências. A familiaridade do catador com o lixo domiciliar fica evidente e mostra que o hábito de guardar

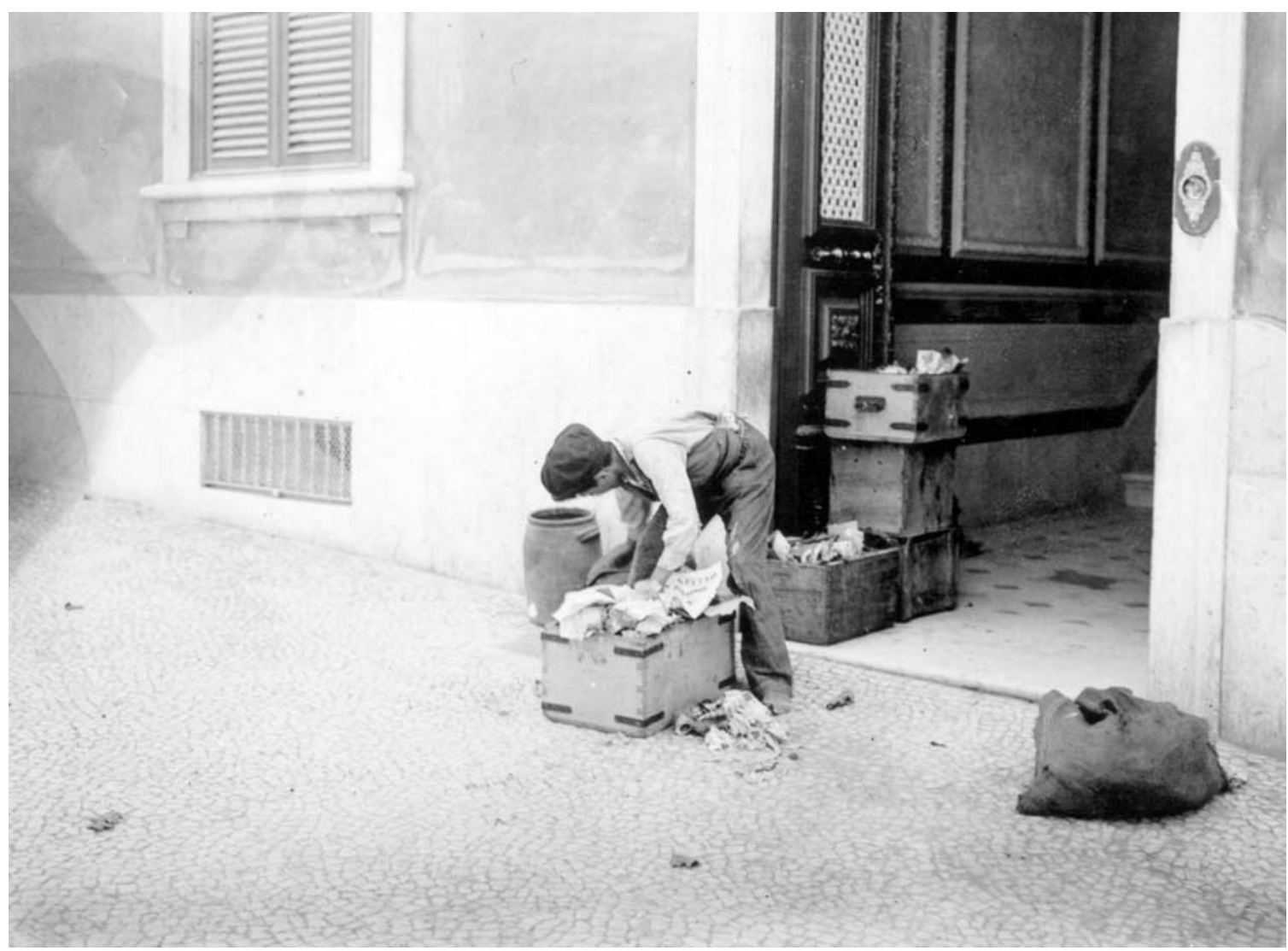

Figura 37 - Joshua Benoliel. Catadores em Lisboa, 1906-1918, gelatina a partir de negativo de vidro. Acervo do Arquivo Fotográfico da Câmara Municipal de Lisboa, Lisboa. 
o lixo em casa era corriqueiro e freqüente, levando os catadores a ter uma rotina de coleta com a permissão dos residentes (Figura 38).

A catagem de sobras e rejeitos que a cidade excluía e expunha ocorria também em depósitos de rejeitos na cidade. Sem muros ou quaisquer limites, os rejeitos da cidade eram vasculhados por pessoas de todas as idades e em um dos registros de Benoliel encontra-se este componente de vasculhar para sobreviver (Figura 39).

Além do hábito de deixar o lixo em caixotes nas portas das casas, também havia o hábito de jogar na própria rua os detritos produzidos. $\bigcirc$ jornal O Século trouxe, em diferentes momentos, reportagens abordando esse problema, sendo que em uma delas lemos:

Em um dos dias da semana passada, na rua do Arco da Graça, uma mulher lançou da janella para a rua um volume bastante volumoso, contendo residuos de peixe e restos de comida. Como este facto presenciado pelo guarda civico no 783, a quem por alcunha chamam o Cabrito; este immediatamente subiu escada acima, resolvido a proceder á competente autoação, como de facto procedeu, e muito bem.

Porém, a mulher é que não gostou da intervenção do guarda e veio para rua, berrando e fazendo um barulho tal, que d'ali a pouco estava rodeada e uma grande multidão, que, em vez de applaudir o acertado e justo procedimento do civico, ainda contra elle protestava,
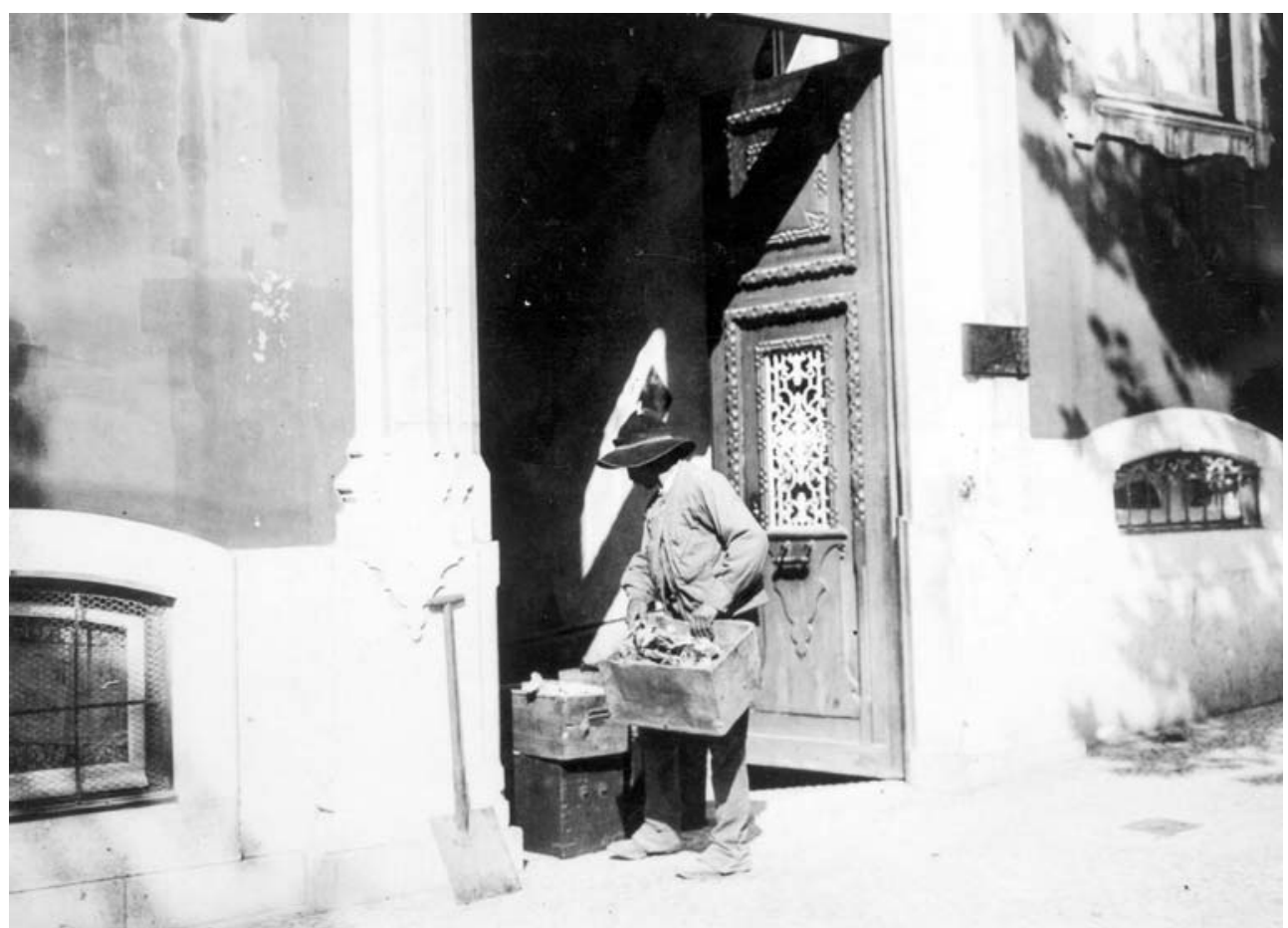

Figura 38 - Joshua Benoliel. Catadores em Lisboa, 1906-1918, gelatina a partir de negativo de vidro. Acervo do Arquivo Fotográfico da Câmara Municipal de Lisboa, Lisboa. 
dizendo que elle não devia ter multado a mulher, porque era uma obra de caridade dar de comer aos gatinhos ${ }^{46}$.

Do que vem das águas... Fabricando Anjos

Princípio do século tanto para São Paulo como para Lisboa vê surgir o mal que vinha pelas águas... $\bigcirc$ tifo invadia os lares e ceifava vidas em especial de crianças, sempre mais suscetíveis de adoecerem e acabavam sendo levadas à morte prematura, muitas vezes pelas más condições de vida e existência. Os agentes transmissores da doença eram citados como vindo de diferentes fontes: águas contaminadas, alimentos crus contaminados, moscas e ausência de tratamento de esgoto e o contato direto com pessoas contaminadas.

Certos hábitos da nossa população também contribuem para prosperidade desses mensageiros de doenças. [...] Assim é que o uso do papel hygienico nas latrinas, por exemplo, ainda carece de propaganda em S. Paulo.Em vez do papel hygienico, que uma vez usado seria lançado dentro da bacia da latrina e se desfaria na agua do exgotto, assim impedindo o entupimento daquella, usa muita gente de jornaes ou outros papeis, que, pela sua consistencia, não

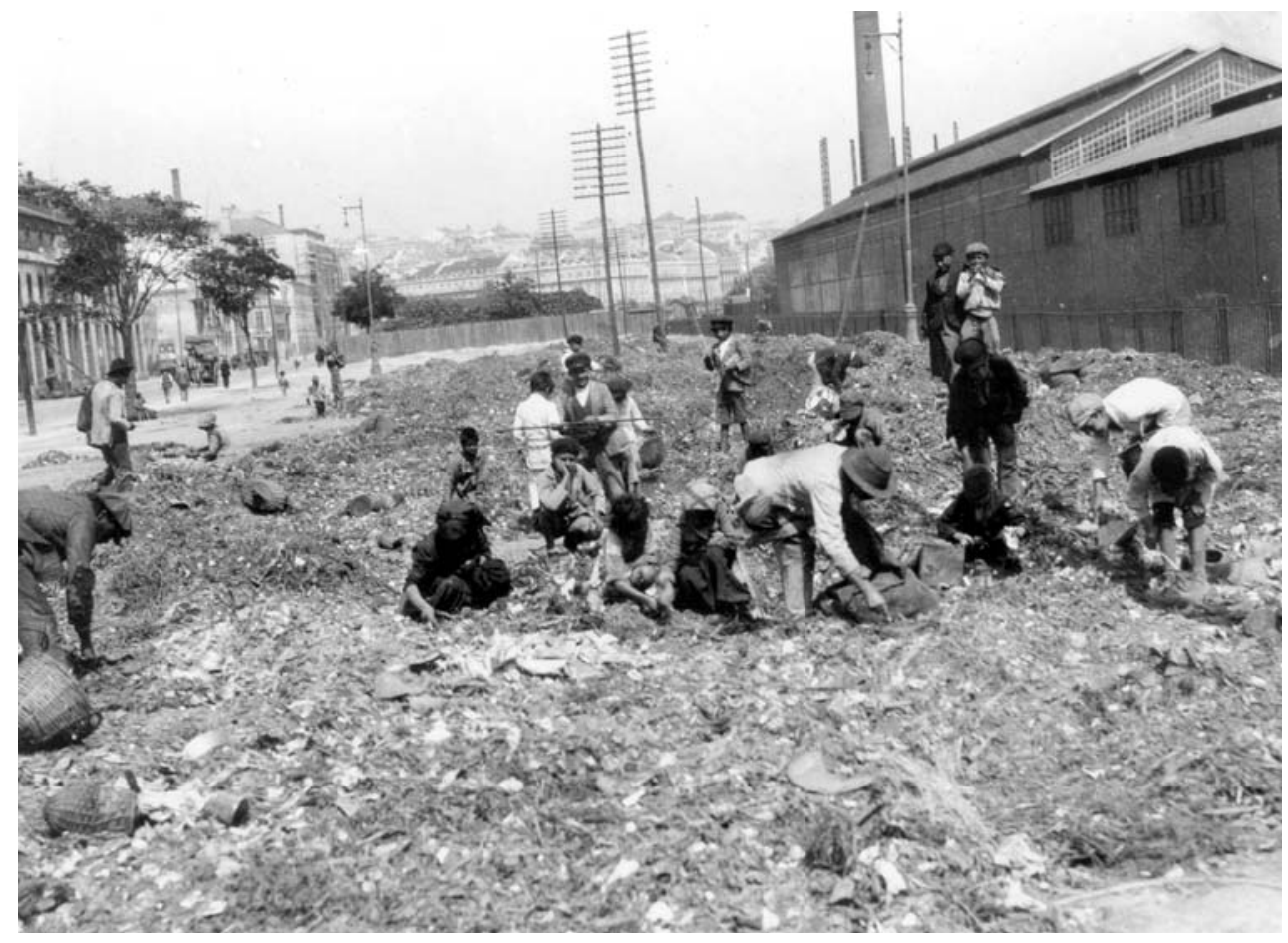

Figura 39 - Joshua Benoliel. Catadores em Lisboa, 1906-1918, gelatina a partir de negativo de vidro. Acervo do Arquivo Fotográfico da Câmara Municipal de Lisboa, Lisboa.
46.A ESTHETICA e a Limpeza da Cidade. O Século, Lisboa, 20 set. 1911. 
47.Ver o estudo de F. Borges Vieira (1922, p. 24-25). podem ser collocados dentro de latrinas sem intupil-as. Após o uso são por este motivo, lançados numa caixa ao lado, quando não no proprio chão, onde servem de pasto ás moscas. Estas, na occasião em que os moradores da casa tomam as refeições, saem das latrinas e vão passear sobre os alimentos na mesa de jantar, espalhando com as patas, defecando e regorgitando os germes que de lá trouxeram, muitas vezes bacillos typhicos ${ }^{47}$.

A questão da higiene de latrinas e o uso indevido de papéis para as mesmas preocupava por todos os motivos especificados acima, além de ser um indício de más condições de vida e habitação. Nos registros de Paula Souza, o tema das latrinas comuns aparece em suas imagens e chega a receber legendas específicas. É o caso da Figura 40 , em que consta a seguinte legenda: "Cortiço do Snr. Gordinho - a primeira porta é a latrina commun abrindo-se para a rua".

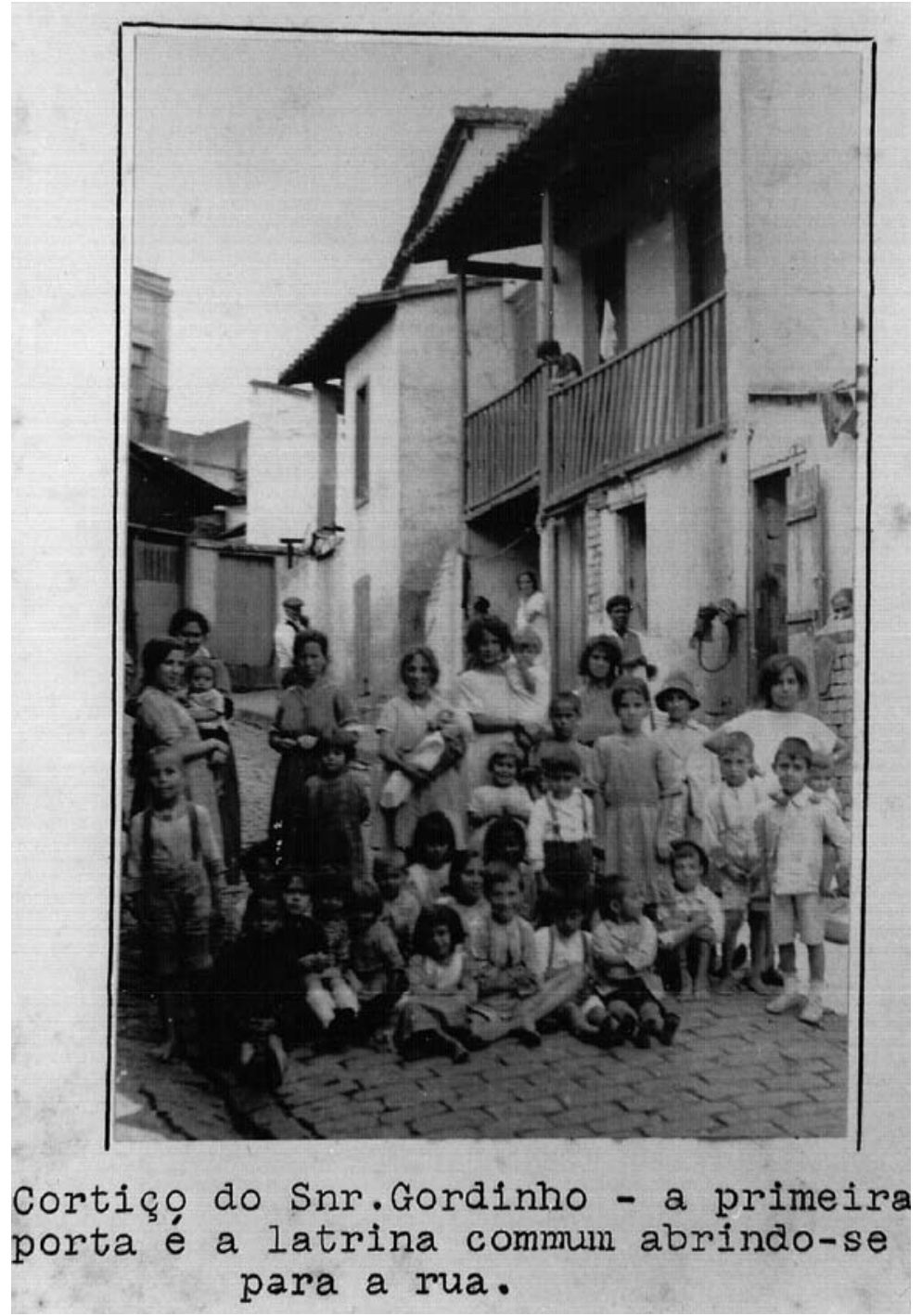

Figura 40 - Geraldo Horácio de Paula Souza. Cortiço em São Paulo, 1919-1925, gelatina a partir de Kodak Graflex Auto 4"x 5" Banoh $x$ Lomb. TESSAR, f.45. Acervo da Biblioteca Faculdade de Arquitetura e Urbanismo da USP, São Paulo. Reprodução do Laboratório da FAUUSP. 
registro, tomado de seu exterior, tem posicionado à sua frente um número grande de pessoas, dentre elas mulheres e crianças, provavelmente as únicas que ficavam em casa durante o dia, momento em que o registro foi feito. A quantidade de pessoas, fotografadas formando um grupo, procura enfocar o grande número dos que se serviam desta latrina e, de certa forma, procurava mostrar que as maiores vítimas suscetíveis de doenças eram as próprias crianças.

A cidade de São Paulo conviveu com surtos epidêmicos de tifo nos anos de 1914 e, posteriormente, em 1921. Nos dois casos, devido ao fornecimento para a população de água vinda do rio Tietê. Além desta via de contaminação proveniente da água, outras surgiam como responsáveis pelo aumento do número de casos da doença. Era o caso do leite e das frutas contaminados e ingeridos crus, as moscas, e o próprio contato com os portadores dos bacilos (na maioria dos casos, contaminação vinda por fezes e urina, e, mais extraordinariamente, escarro e suor).

Em Lisboa, a situação do tifo também não era muito diferente. Para especialistas, nesta altura Portugal podia ser considerado um país tífico. Eram os cortiços, sem dúvida, uma das formas de habitação que mais preocupavam todos os que se propunham a normalizar os espaços urbanos. Tanto em São Paulo quanto em Lisboa eram espaços freqüentemente visitados, e procurava-se fazer todo tipo de críticas sobre o modo de vida em tais lugares. Espaços saturados de odores... espaços da aglomeração inculta, carregada de hábitos e modos de viver que nem de longe eram consideradas como ideais. Os registros fotográficos de Paula Souza para São Paulo e os de Benoliel para Lisboa refletem este tipo de preocupação.

Dentro de muros, atrás de portas

Lisboa, sendo uma cidade de encostas e colinas, debruçada sobre o mar e com um casario antigo, ganhava através do tempo - quer através da literatura, quer da poesia ou mesmo da música - a fama de abrigar em suas ruelas estreitas e sinuosas uma população de caráter duvidoso, com feitio dado às desordens e aos crimes. Foi assim com Alfama, Madragoa e Mouraria, entre outros: bairros construídos a partir de um imaginário de vida mundana e noturna, vistos como sendo carregados de vícios e pouca moral.

A maioria desses bairros, no entanto, eram na realidade compostos por operários e trabalhadores de poucas habilitações solidarizados pela pobreza e pela fome. Com um casario quase sempre muito apertado e compartilhado por grande número de pessoas, a vida transcorria quase sempre na rua, às vistas de todos. Conforme nos descreve um articulista do jornal $\bigcirc$ Século, em matéria especial acompanhando o subdelegado de Saúde de Lisboa Dr. Carlos Santos em visita ao bairro de Alfama, numa reportagem que contou com clichês de Benoliel $^{48}$ (Figuras 41 e 42): 


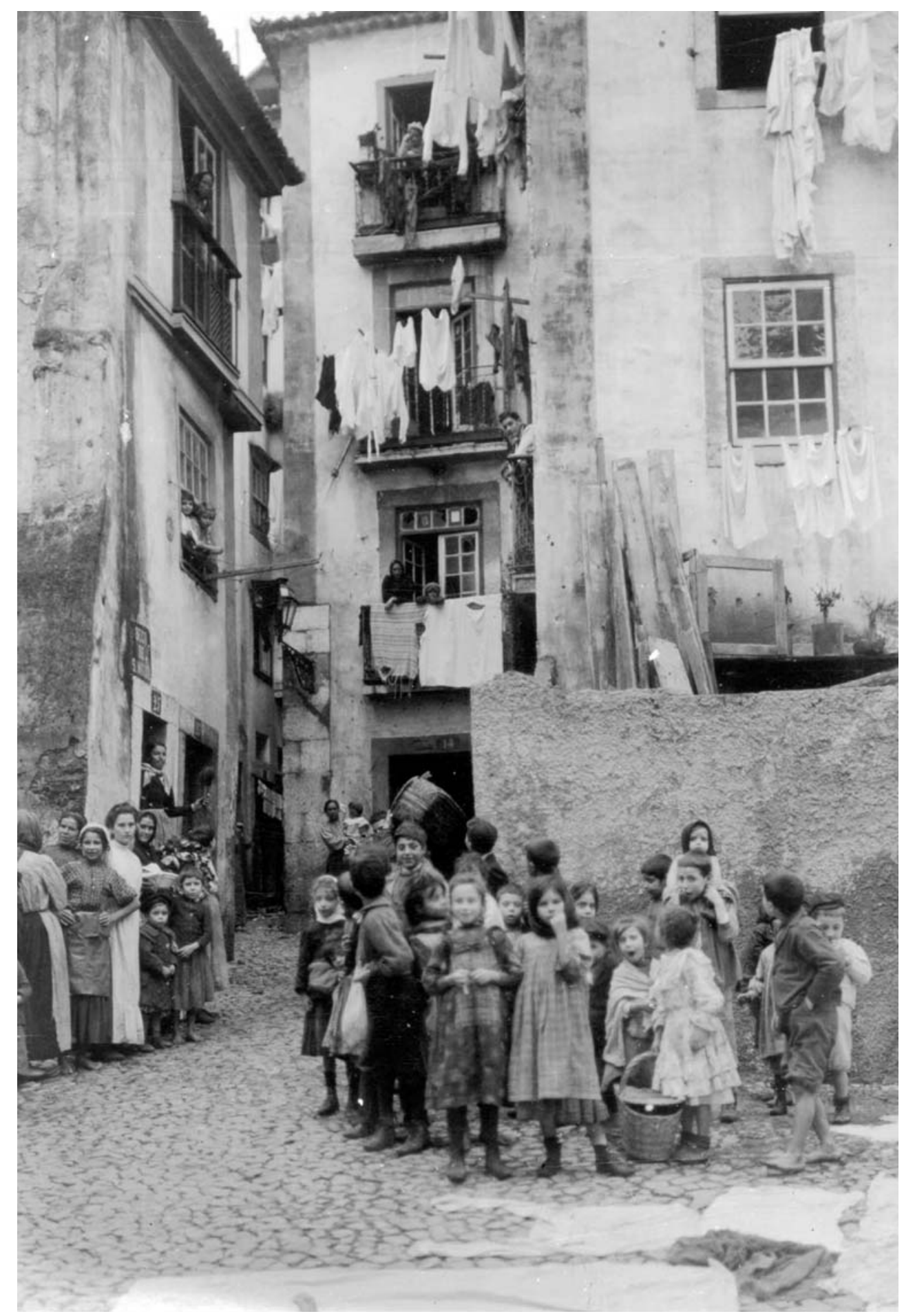

Figura 41 - Joshua Benoliel. Cortiço em Lisboa, 1906-1918, gelatina a partir de negativo de vidro. Acervo do Arquivo Fotográfico da Câmara Municipal de Lisboa, Lisboa. 
Como as casa são apertadas e escuras, aquela gente vive na rua. D'ai a legião enorme de garotos, semelhante a formigueiros, que enxameia o bairro. Trabalha-se, cozinha-se, lava-se e cose-se á porta de casa. [...] No pateo do Penereiro, por exemplo, um sapateiro batia sola sobre o joelho, duas mulheres, sentadas no lageado, remendavam uma vela de lona, emquanto uma outra ainda estendia nas cordas alguns trapos encardidos.

No beco do Almotacé, nas soleiras das portas, as mulheres cozinhavam e cosiam, cantando e conversando umas com as outras ${ }^{49}$.

Uma das principais características dos cortiços era a vida vivida aos olhos de todos. A solidariedade em torno das mesmas dificuldades fazia com que, para além da ausência de espaço, houvesse familiaridade entre os diferentes moradores. Dentre estes trabalhadores mal remunerados ainda havia aqueles que se encontravam numa via de exclusão: quer pela doença - já que muitos, levados por más condições de vida e trabalho, ficavam doentes, em sua maioria tísicos e sifilíticos -, quer pelo desemprego, transformando-se em vadios e gatunos. Nestas duas últimas categorias se incluíam muitos ex-trabalhadores que, movidos pela indolência ou fascínio pelo ganho fácil, dedicavam-se à mendicância ou ao furto.
49. LISBOA miserável. Como se vive em Alfama. Uma visita áquele centro domiciliario de operarios miseravelmente pagos, de vagabundos,famintos e gatunos. OSéculo, Lisboa, p. 1, 21 ago. 1912.

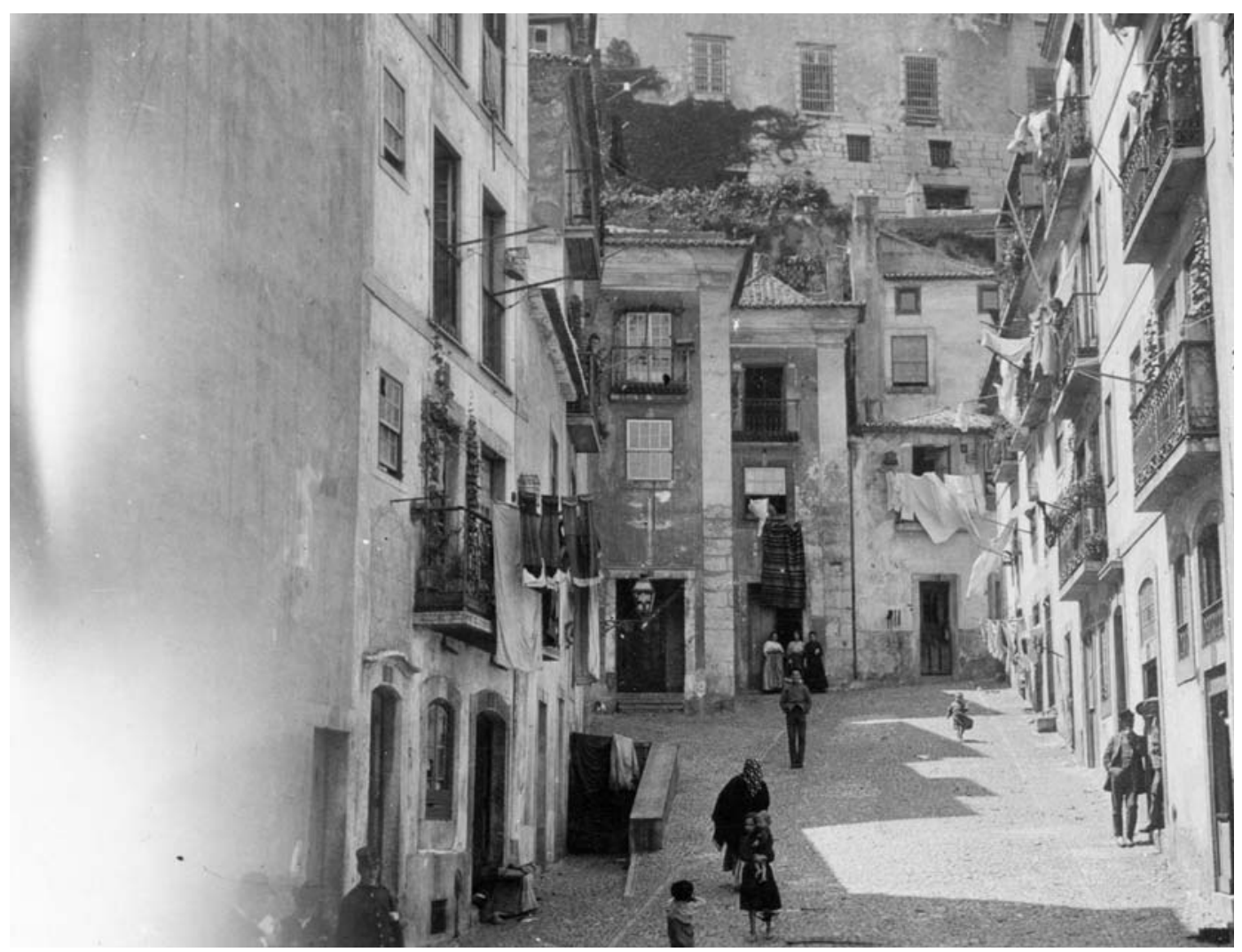

Figura 42 - Joshua Benoliel. Cortiços em Lisboa, 1906-1918, gelatina a partir de negativo de vidro. Acervo do Arquivo Fotográfico da Câmara Municipal de Lisboa, Lisboa. 
Os registros de Benoliel ressaltam exatamente a miséria e o grande número de crianças que transitavam por todo o bairro. As moradias estreitas, com janelas de frente para a rua, sempre congestionadas pelas roupas estendidas, confundiam-se com a estreiteza e sinuosidade dos becos que, atrás de si, sempre escondiam alguém a espreitar. Em alguns registros, a decadência das construções estava exibida nas paredes ruídas e carcomidas pelo tempo, descuido ou abandono (Figuras 43 e 44).

São registros arquitetônicos de uma miséria que é, além de material, também social. São registros que passam pelos territórios da exclusão e da marginalidade alfacinha, de onde surgem personagens vítimas de sua própria sorte, integrantes das cifras anuais de doentes que chegavam ao óbito por diferentes enfermidades. Entre as doenças responsáveis pelo maior número de vítimas estava a tuberculose, que atingia famílias inteiras devido ao exíguo espaço de convivência.

Semelhante na conformação à dos moradores de Alfama, a Mouraria guardava em seus becos e vielas estreitos inúmeras casas de tolerância e aproximava-se da primeira no que concernia ao excessivo número de crianças, de vadios e de doentes. Os aluguéis, tal como ocorria com Alfama, eram altos demais para as condições de existência oferecidas. Em sua maioria, sua

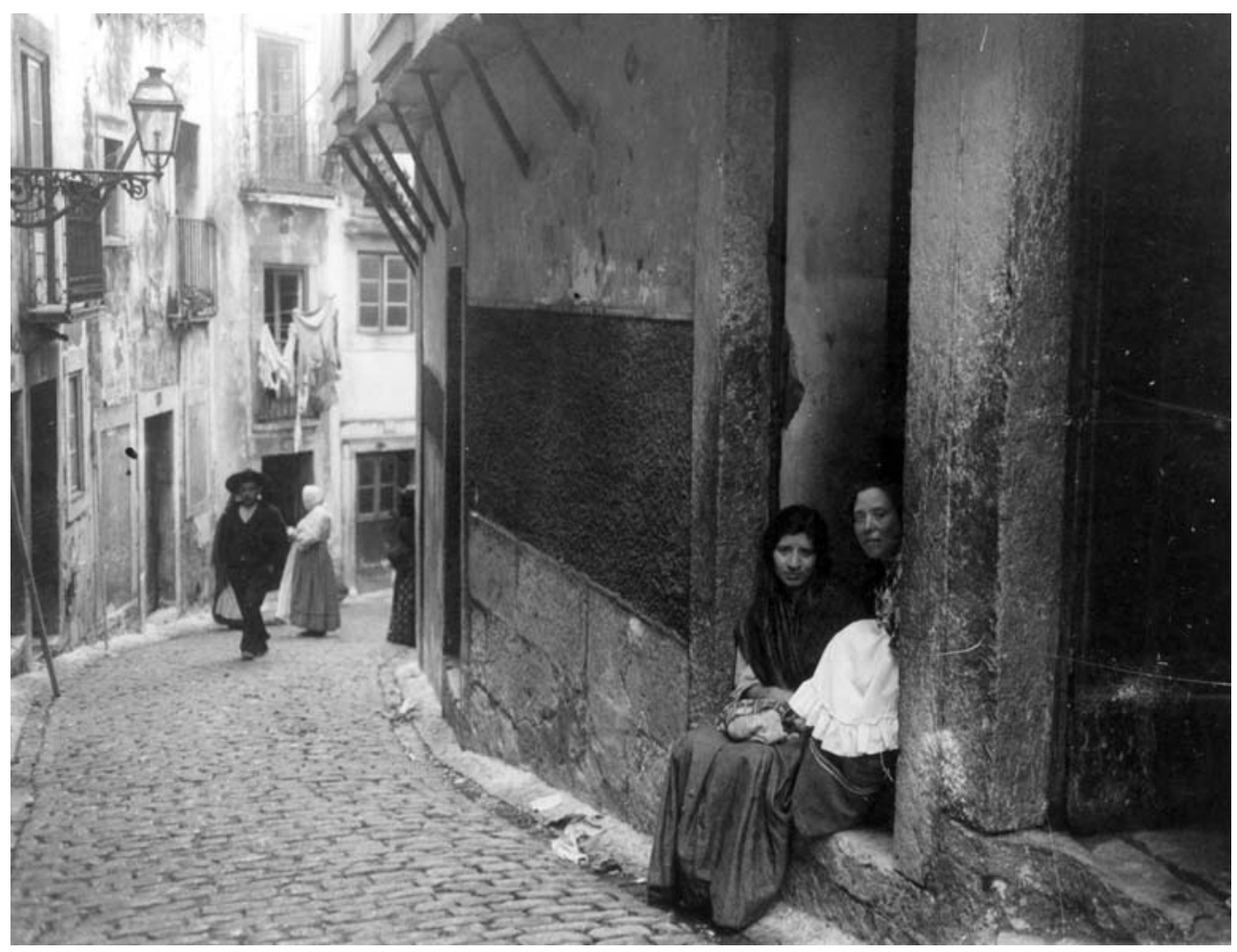

Figura 43 - Joshua Benoliel. Cortiço em Lisboa, 1906-1918, gelatina a partir de negativo de vidro. Acervo do Arquivo Fotográfico da Câmara Municipal de Lisboa, Lisboa. 


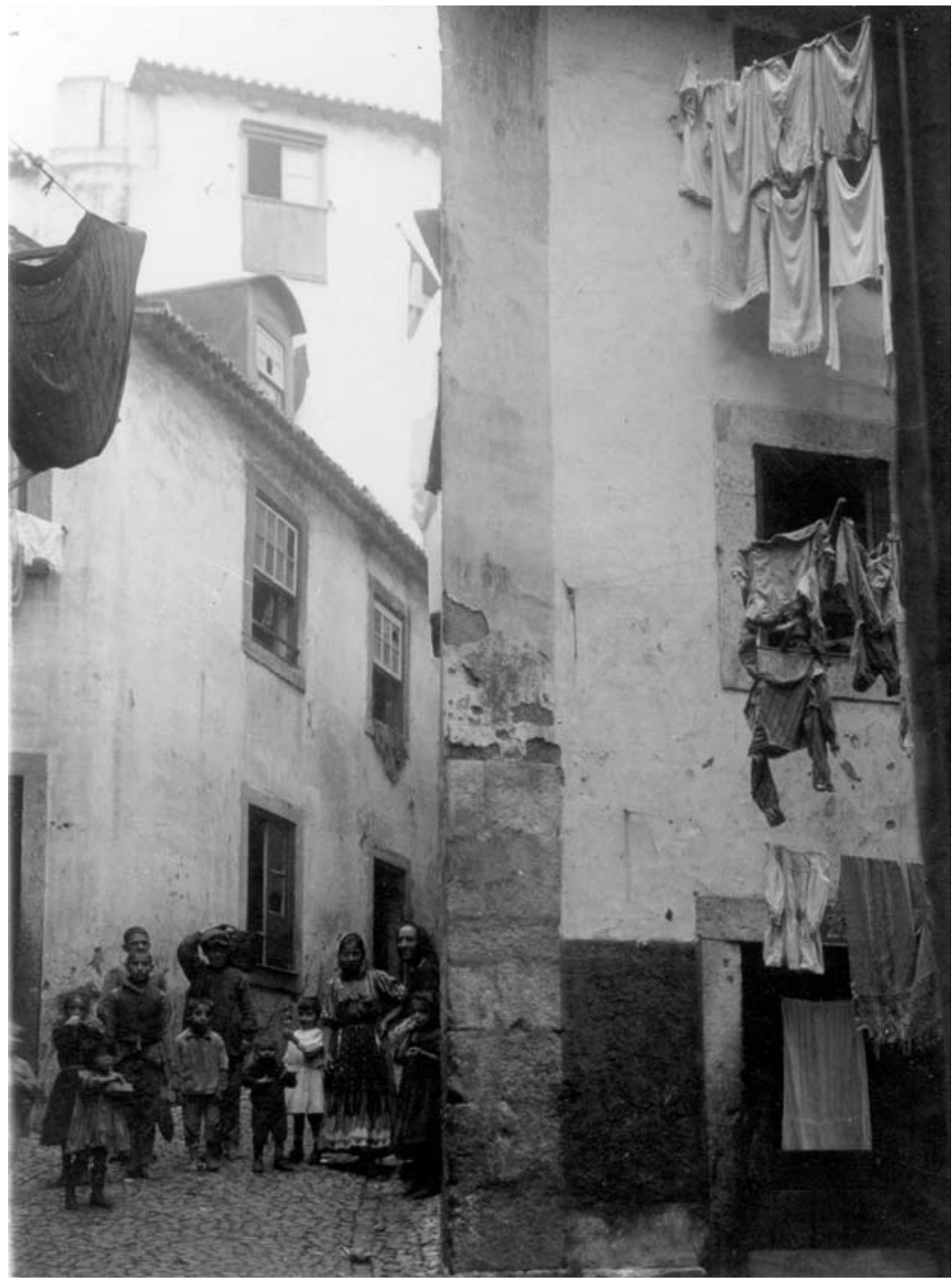

Figura 44 - Joshua Benoliel. Cortiços em Lisboa, 1906-1918, gelatina a partir de negativo de vidro. Acervo do Arquivo Fotográfico da Câmara Municipal de Lisboa, Lisboa.

população era formada por vendedores ambulantes, moços de fretes, e muitos, muitos tísicos. A descrição do articulista para este bairro segue da seguinte maneira:

Na rua de S. Pedro Martir, onde se aglomeram os depositos de ovos e carnes salgadas dos negociantes da praça e onde se fabrica calda de tomate, se curtem azeitonas e se fazem chouriços, por processos que se fossem conhecidos pelos consumidores declarar-theshiam boycottage, o cheiro constitue um grave perigo para os seus moradores. [...] Ali vive a miseria, com todo o seu horrivel sequito de imundicie, depravação, crimes, vicios e doenças hereditarias ${ }^{50}$.

A argumentação construída pelo articulista seguia em torno de relacionar, o tempo todo, a miséria moral à miséria física, com odores, vícios e 
condição moral levando à degeneração e exclusão social. Os odores degustativos aliavam-se aos odores dos vícios e às práticas consideradas depravadas.

O médico sanitarista, inquirido pelo repórter sobre o que fazer diante de tão graves problemas, responde:

Todas as obras aqui são inuteis. $\bigcirc$ unico remedio, a unica coisa aqui ha fazer-se é arrazar tudo isto, não deixar pedra sobre pedra, mas não a camartelo ou a alvião, que isso seria um grave perigo para a cidade pela poeira e pelos microbios que levantaria. Devia ser destruida pelo fogo ${ }^{51}$.

A solução, no entanto, não chegou nem formato nem no modo proposto pelo médico sanitarista e, ao contrário das expectativas, os problemas ainda conseguiram alastrar-se e atingir outros bairros localizados em outros pontos de Lisboa. As condições de vida e salário levavam a um aumento diário do exército de pedintes e começaram a gerar, nas autoridades envolvidas, a preocupação com a mendicidade, a vadiagem e com todos os ociosos em geral que habitavam e percorriam ruas e praças da cidade.

Um dos registros de Benoliel sobre esta situação na cidade é o de uma mão que estende uma esmola. Um auxílio anônimo àquele que pede e perambula pelas ruas. Hábito questionado e muitas vezes criticado, já que, em muitos casos, tornava-se um incentivo ao viver de préstimos alheios. A forma do registro de Benoliel é interessante: revela a partir do que exclui. A mão anônima transforma-se na metáfora da sociedade que, por pequenos gestos, acabava por incentivar práticas que levavam à manutenção de vidas marginais. Com pequenos gestos de aparente generosidade, a sociedade ia tecendo as teias invisíveis da imobilização, jogando no anonimato social cidadãos que não conseguiam alinhar-se ao trabalho produtivo (Figura 45).

Diferentes projetos de lei e propostas para a solução da vadiagem nas ruas da cidade proliferavam na mesma proporção do número de pedintes. Tanto que, em um determinado ponto, a imprensa diária e ilustrada começou a publicar artigos atacando o número sempre crescente de ociosos pelas ruas de Lisboa. Em um deles, em linhas rápidas, o articulista procurava definir suas origens:

$\bigcirc$ exercito dos mendigos é enorme. Há-os recrutados em todas as edades, d'ambos os sexos, de diversas taras e deformidades. Vêem-se, mal saídos dos braços das mães, invadindo os estabelecimentos, assaltando os transeuntes, dormindo aos pares nos portaes, á chuva e ao frio; vêem-se aleijados, expondo as suas miserias n'um mostruario de feira sertaneja; onde houver um episodio festivo é contar com um esquadrão de pedintes ${ }^{52}$.

A metáfora do articulista - de o número de vadios pelas ruas ser um exército - procurava dar a dimensão do número exagerado de pedintes. Nos registros de Benoliel (Figuras 46 e 47), eles estavam distribuídos por diferentes pontos e são flagrados por nosso repórter. Nos bancos do Rossio e da praça da Figueira, na praça do Comércio e pelas ruas do Chiado, novos e velhos, todos desfrutando apenas e tão somente da vida que passava ao largo, sem 


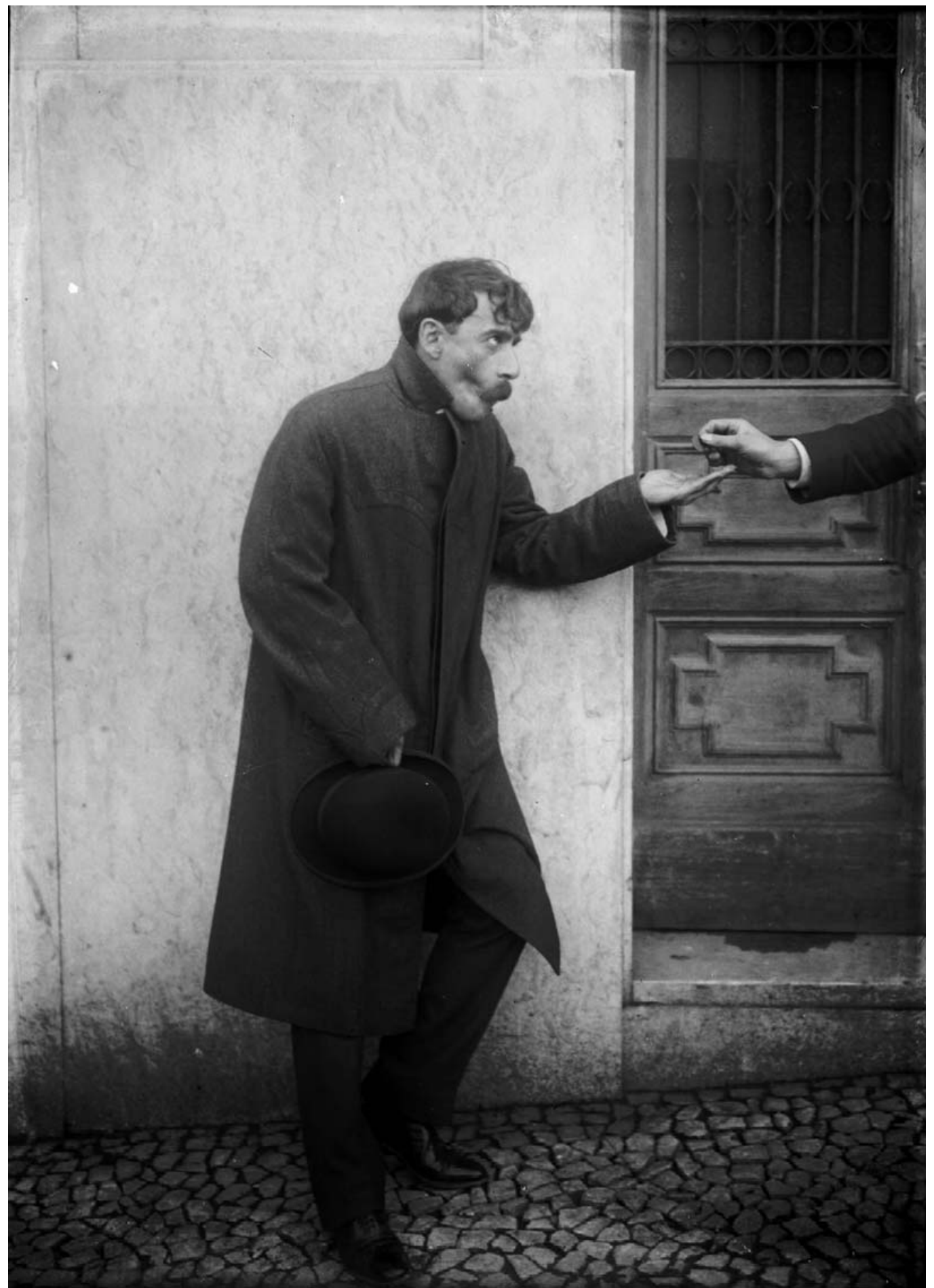

Figura 45 - Joshua Benoliel. A mão e a esmola, 1906-1918, gelatina a partir de negativo de vidro. Acervo do Arquivo de Fotografia de Lisboa. 


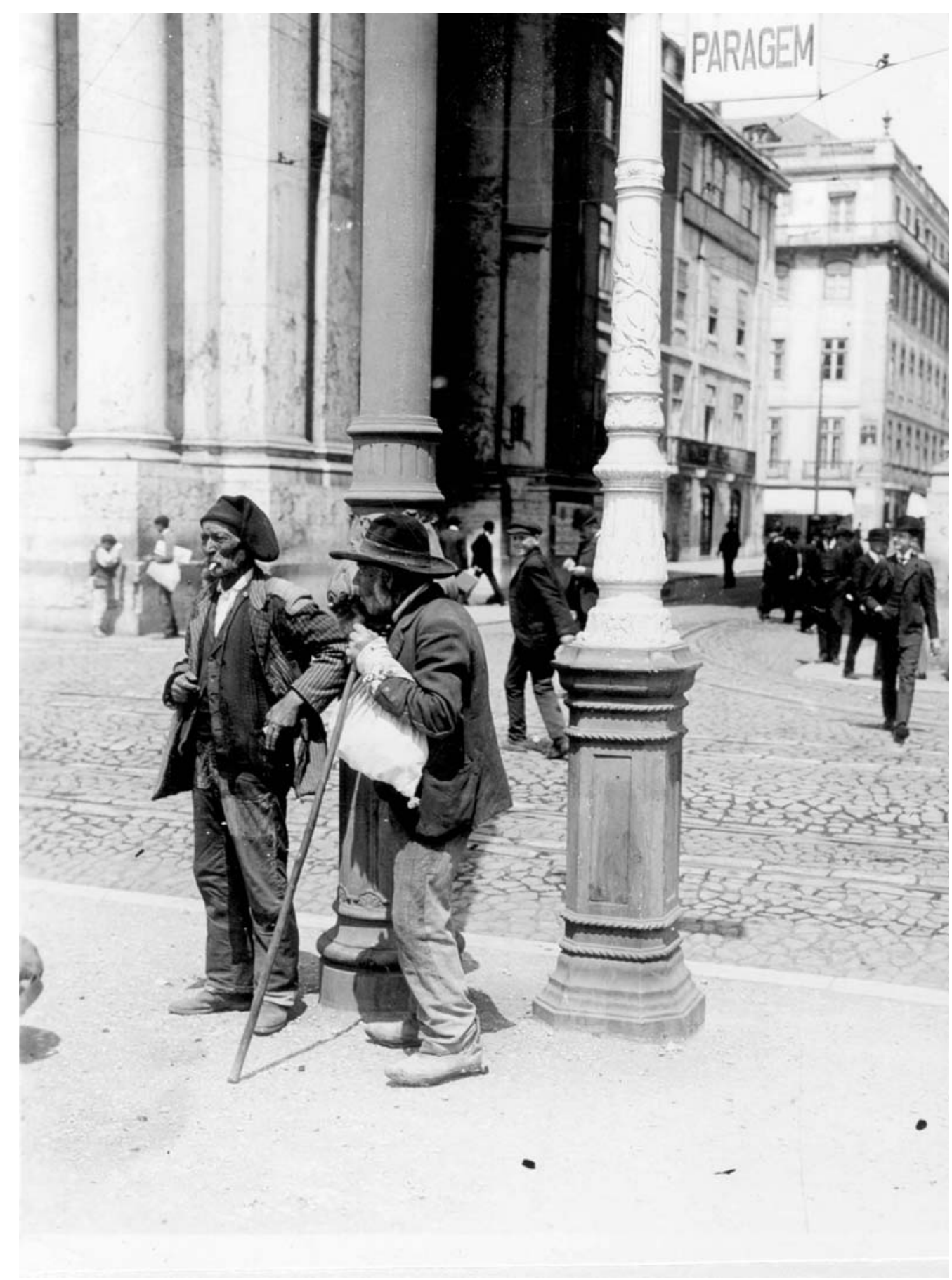

Figura 46 - Joshua Benoliel. Mendigos em Lisboa, 1906-1918, gelatina a partir de negativo de vidro. Acervo do Arquivo Fotográfico da Câmara Municipal de Lisboa, Lisboa. 


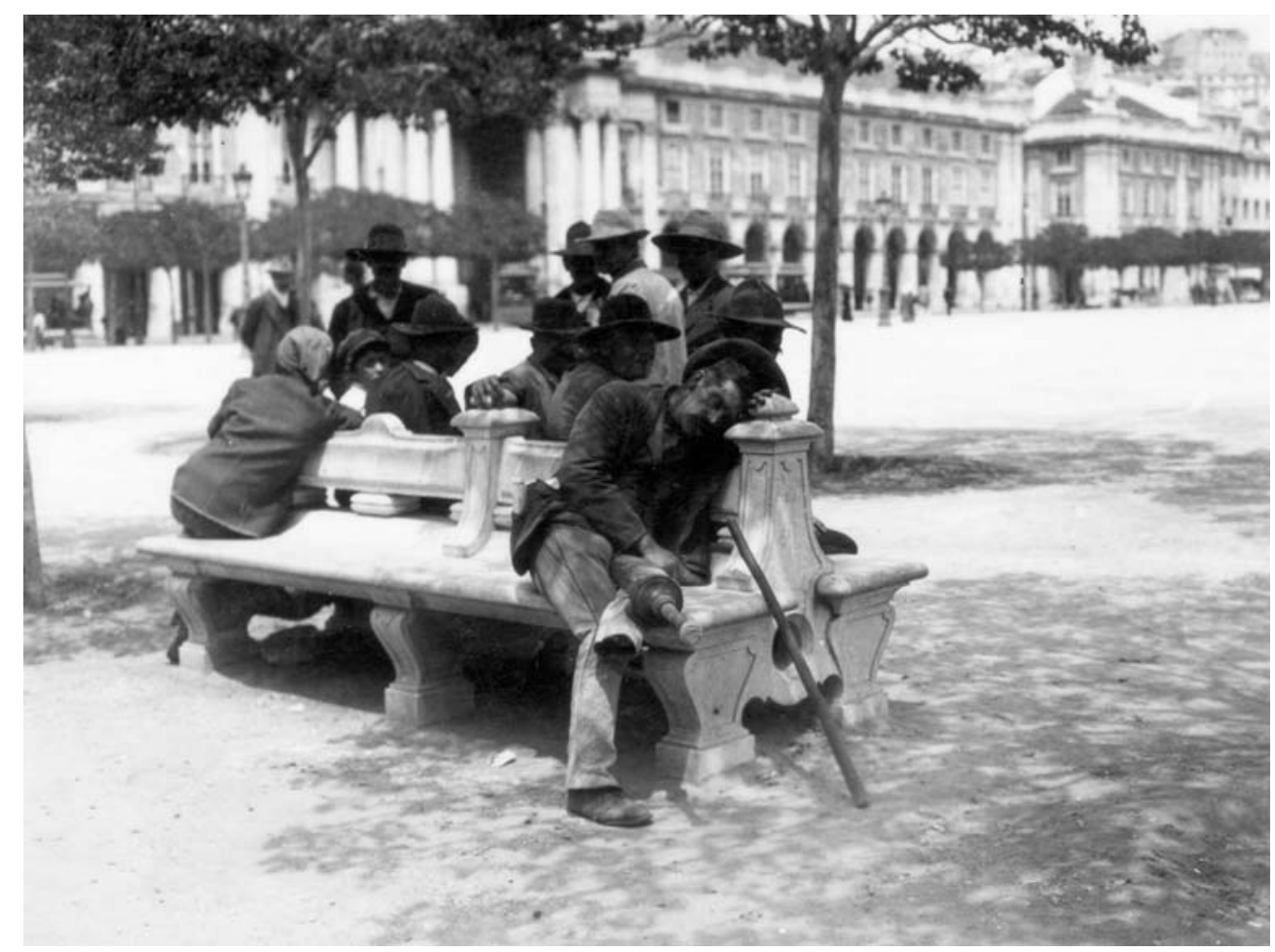

Figura 47 - Joshua Benoliel. Mendigos em Lisboa, 1906-1918, gelatina a partir de negativo de vidro. Acervo do Arquivo Fotográfico da Câmara Municipal de Lisboa, Lisboa.

trabalho, sem pressa, no ritmo dos que nada esperam além de uma oportunidade de dinheiro fácil, vindo por mãos caridosas ou pela distração alheia, na forma de pequenos e oportunos furtos.

Não apenas homens, mas também mulheres entregavam-se à vida de pedinte e, em alguns casos, já estavam completamente assimilados a determinados pontos da cidade, tornando-se conhecidos daqueles que teriam de zelar pela segurança da sociedade.

A idade também não parecia ser um impedimento para o exercício da marginalidade e, conforme diferentes relatos, o número de vadios abarcava pessoas de diferentes faixas etárias. Benoliel, por exemplo, os registra não apenas em sua fase madura, em que a velhice seria o maior dos impedimentos. Aparecem também como homens jovens ou mesmo crianças, como na Figura 48. Neste registro, Benoliel surpreende um menino, com idade provável bem inferior aos 10 anos, que, distraído, "sacia" sua sede com sobras deixadas em um copo sobre uma mesa em alguma esplanada da cidade. $\bigcirc$ registro foi produzido para compor uma reportagem sobre um dia de calor em Lisboa. Mas, para além de simplesmente abordar o tema de pauta, Benoliel sugere muito mais com seu registro. Ele revela, para além da origem paupérrima do menino, um outro sério problema: vivendo nas ruas e das sobras de outras existências, tais 


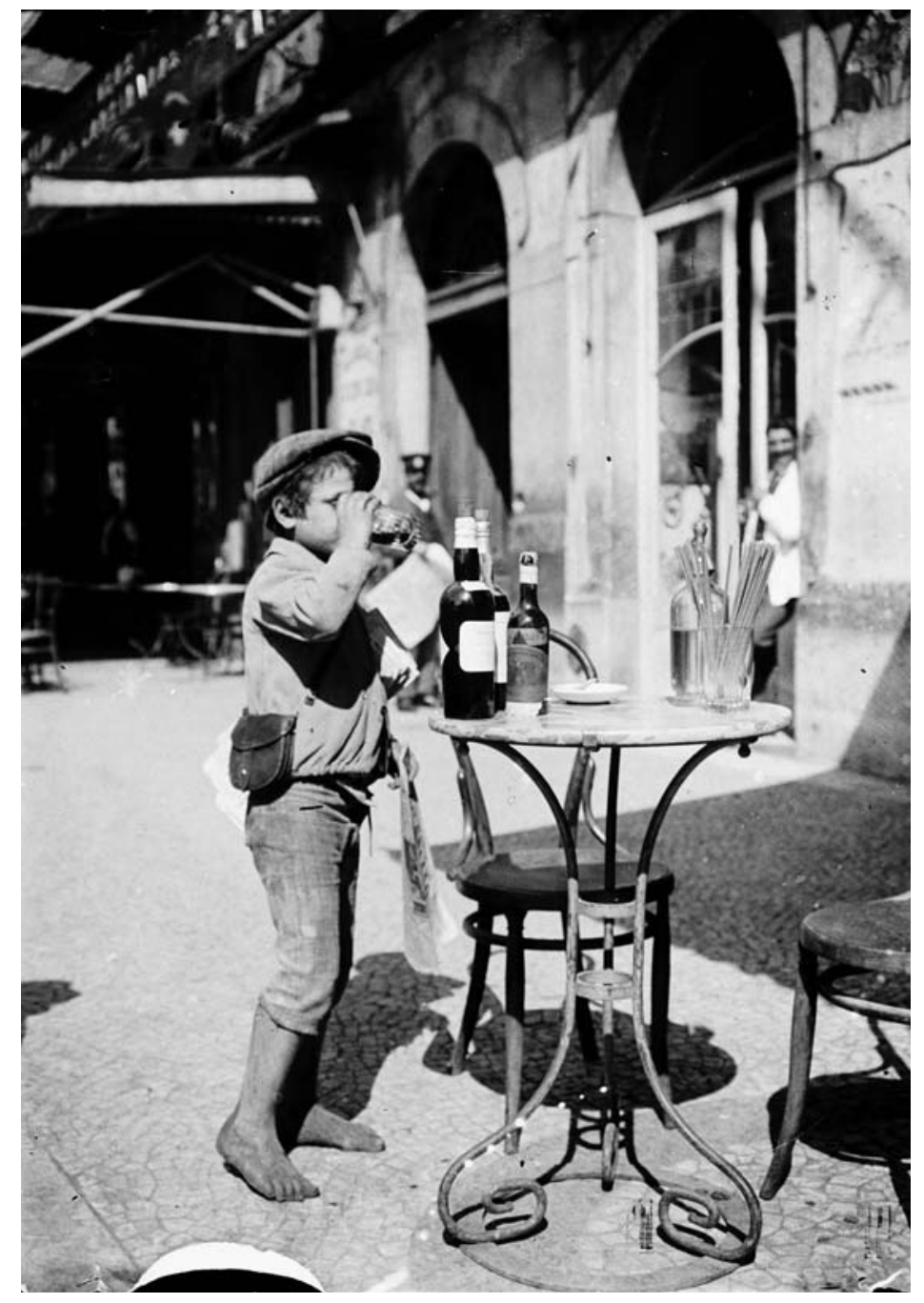

Figura 48 - Joshua Benoliel. Vicio \& infância, 1906-1918, gelatina a partir de negativo de vidro. Acervo do Arquivo de Fotografia de Lisboa.

jovens pedintes cedo começavam a ganhar intimidade com outras formas de vícios que não apenas o de esmolar - a bebida alcoólica sendo uma delas.

Para muitos, tal modo de vida acabava por leválos às instituições de acolhimento de menores infratores, ou mesmo ao abandono. Em um dos registros de Benoliel, os meninos são vistos atrás de grades. É o calabouço instalado no Convento de S. Francisco. Por trás de sua reclusão, os olhares inquiridores e desafiadores miram a objetiva e não se recolhem numa tentativa de anonimato. Ao contrário, dão-se a conhecer.

Para as meninas, a prostituição chegava como mais um elemento desse contexto de miséria e de busca para manter a sobrevivência. Os ingredientes para tais histórias eram sempre os mesmos: miséria familiar, seguida por promessas de melhoria de condições de existência e perpetuação de uma vida ligada à prostituição e a outras formas de exploração. A melhoria de vida prometida não chegava nunca, e as dificuldades não cessavam, levando muitas dessas mulheres 
a não obter com os seus corpos o suficiente para seu alimento, já que a maior parte do dinheiro ganho ia para o pagamento dos quartos de aluguel e para o sustento de profissionais da exploração feminina. Os clientes vinham de diferentes procedências e ganharam a descrição de uma destas toleradas ${ }^{53}$ : "Os frequentadores do estabelecimento são carroceiros, maritimos, peixeiros e soldados, os magalas, chamou-lhe ella. A's vezes custam muito a aturar, veem borrachos ${ }^{54}$ a cair, não são dellicados e pagam mal"55.

Para além de seus próprios clientes, estas toleradas tinham que conviver com a exploração de rufiões ${ }^{56}$ - exploradores do seu trabalho e detentores da maior parte do dinheiro que conseguiam fazer. De outro lado, conheciam a exploração e o descaso dos próprios policiais, que eram, em muitos casos, os responsáveis por seus defloramentos e conseqüente introdução no mundo da prostituição.

Os diferentes vadios - que, organizando-se em grupos e vivendo desta maneira, perambulavam pelas ruas de Lisboa - possuíam códigos de conduta próprios, determinando áreas de atuação e delimitação de espaços a serem ocupados dentro da cidade. De modo que, entre eles, havia até mesmo um código que indicava pontos onde não resultava o pedido de esmolas: umbrais e portas de residências ou comércios que se recusavam a dar esmolas recebiam um círculo pintado, significando que ali não adiantava mendigar.

Assim, em meio a uma série de discussões sobre o chamado problema da vadiagem nas ruas de Lisboa, a lei portuguesa acabou por encontrar uma definição que distinguia o vadio do mendigo. Deste modo, para a Lei de 20 de Julho de 1912, o mendigo era o indivíduo que, mesmo estando apto ao trabalho, não o fazia e era encontrado na mendicância. $\bigcirc$ vadio era aquele que, com mais de 16 anos, não tinha qualquer meio de subsistência, não exercia qualquer tipo de atividade remunerada e não era capaz de comprovar qualquer tipo de impedimento. Para o caso português, vadiagem e mendicidade eram assuntos diferentes, apesar de representarem modalidades da ociosidade. Resumidamente, o que se tem, segundo esta vertente, era que a mendicidade seria apenas o pedir esmolas, enquanto a vadiagem significaria a ausência de domicílio aliada à ausência de busca por trabalho ou qualquer outro meio de subsistência. No entanto, eram assim mesmas vistas como estágios de criminalidade e que, portanto, deveriam ser combatidas ${ }^{57}$.

Para o caso de São Paulo, a mendicidade experimentada tinha muito a ver com a Primeira Guerra. Com a crise fabril e o aumento de imigrantes europeus fugindo do conflito, as ruas ganhavam um número cada vez maior de pessoas que se espalhavam pelos arredores da cidade, formando áreas de exclusão semelhantes às encontradas em Lisboa.

\section{Vida nos cortiços da Paulicéia}

Os registros de Paula Souza, sobre as habitações coletivas em São Paulo são muito claros e incisivos. Demorava-se em registrar estes espaços e as formas de viver e morar de seus habitantes. Alcançava-os através de sua objetiva e procurava registrar os elementos constitutivos destes espaços (Figuras 49 a 51 ).
53. Prostitutas que têm o nome inscrito nos registros administrativos e estão sujeitas à inspeção e regulamentação policiais

54. Bêbados.

55. PERCORRENDO Alfama: no fundo do abysmo. O Século, Lisboa, p. 1,13 dez. 1910.

56. Definido como aquele que vive às custas de mulheres ou que briga por elas.

57. Idem, p. 55. 


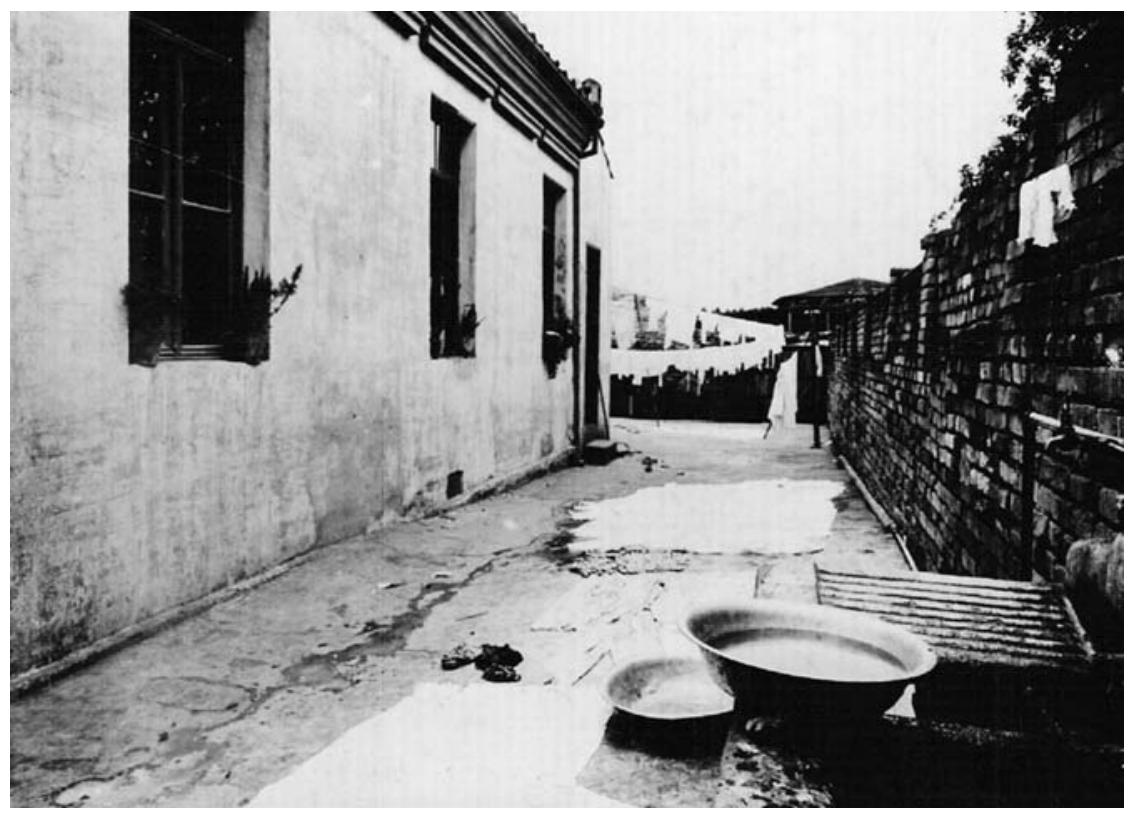

Figura 49 - Geraldo Horácio de Paula Souza. Cortiço em São Paulo, 1919-1925, gelatina a partir de Kodak Graflex Auto 4"x 5" Banoh x Lomb. TESSAR, f.45. Acervo da Biblioteca Faculdade de Arquitetura e Urbanismo da USP, São Paulo. Reprodução do Laboratório da FAUUSP.

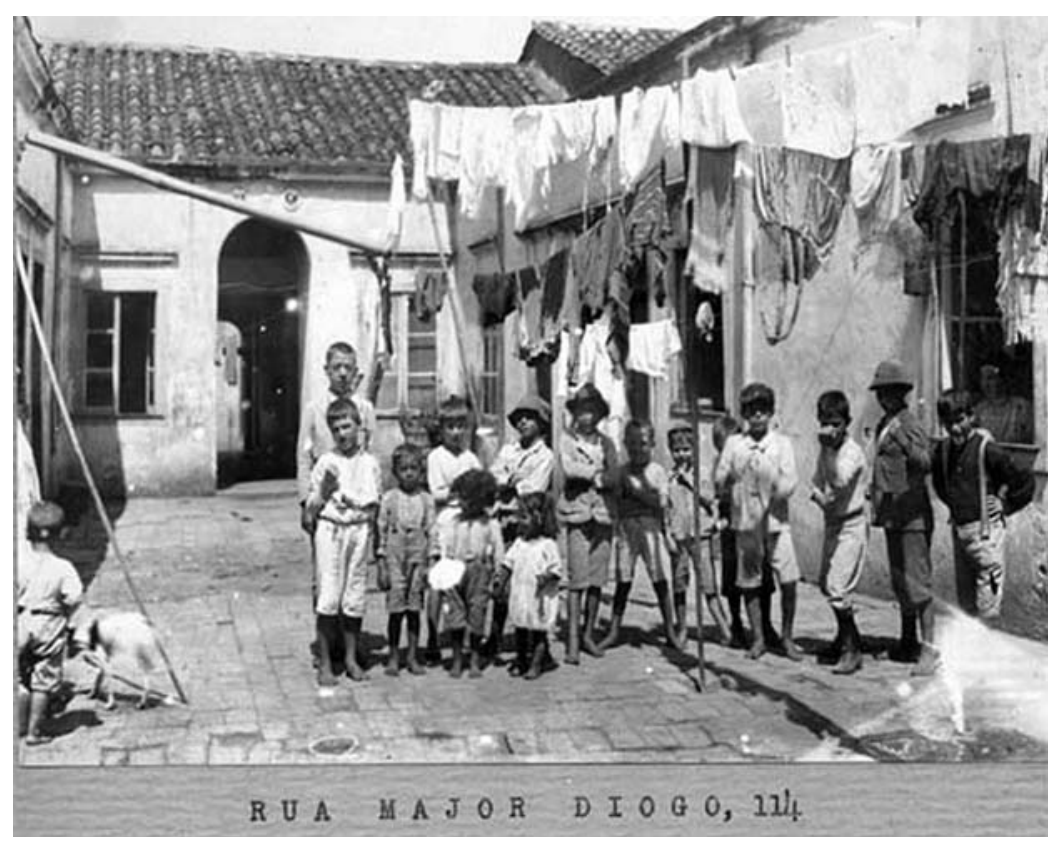

Figura 50 - Geraldo Horácio de Paula Souza. Cortiço em São Paulo, 1919 1925, gelatina a partir de Kodak Graflex Auto 4"x 5" Banoh x Lomb. TESSAR, f.45. Acervo da Biblioteca Faculdade de Arquitetura e Urbanismo da USP, São Paulo. Reprodução do Laboratório da FAUUSP. 


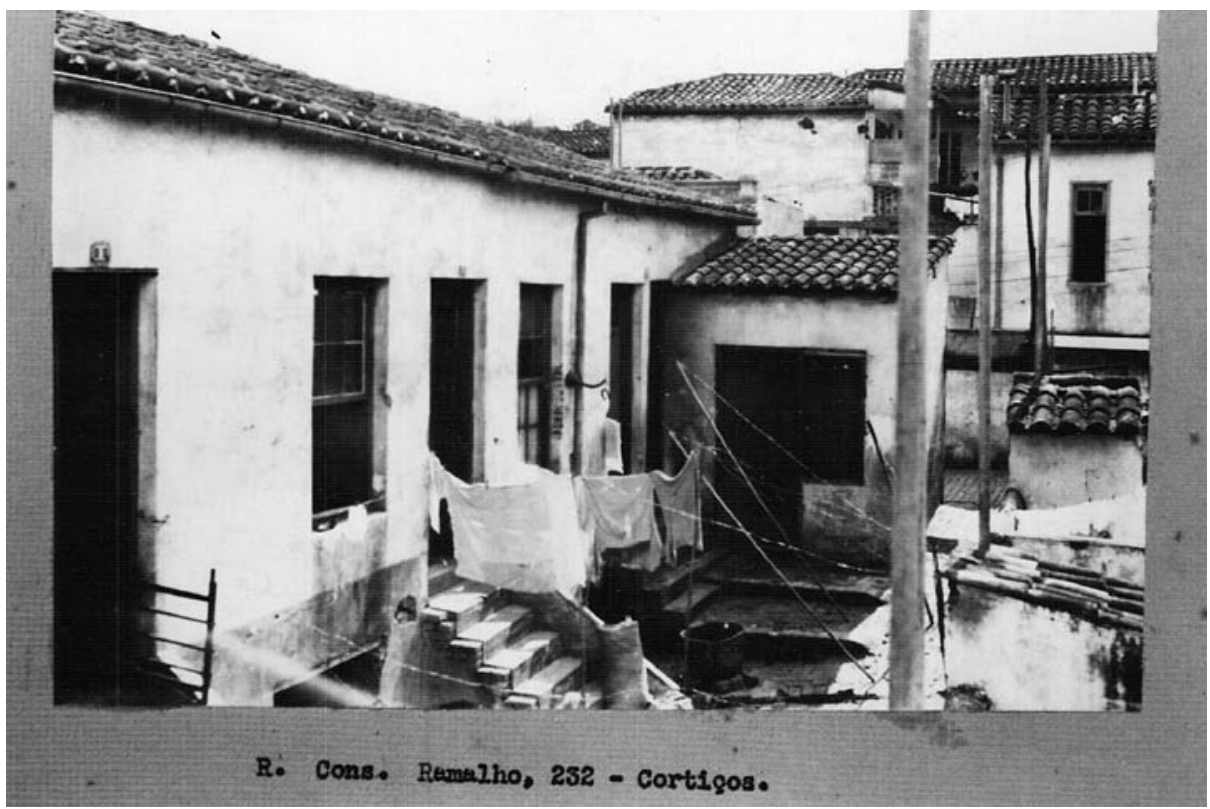

Figura 51 - Geraldo Horácio de Paula Souza. Cortiços em São Paulo, 1919-1925, gelatina a partir de Kodak Graflex Auto 4"x 5" Banoh x Lomb. TESSAR, f.45. Acervo da Biblioteca Faculdade de Arquitetura e Urbanismo da USP, São Paulo. Reprodução do Laboratório da FAUUSP.

Como ocorre na maioria dos seus registros, o elemento humano é excluído em detrimento de outros elementos, como bacias contendo água para a lavagem das roupas que se encontram estendidas ou sendo quaradas, paredes desgastadas e puídas pelo tempo, espaço comum exíguo, compartilhado por muitas e pequenas portas e janelas que serviam como entrada de luz para as habitações comuns às várias e numerosas famílias, que eram lançadas à rua, contaminando e sendo contaminadas por doenças, vícios e toda sorte de imoralidades.

Para o olhar clínico do sanitarista era no cortiço que as diferentes patologias sociais, morais e físicas se manifestavam e onde a educação moral deveria começar. Eram nestes territórios de exclusão social que habitavam alcoólatras, prostitutas, sifilíticos, tísicos, vadios, inválidos, desempregados ou trabalhadores de baixa renda com suas respectivas famílias e em alguns casos suas pequenas vítimas - filhos que cedo passavam a servir como meio de ganho através da caridade alheia.

Esta forma de conceber o espaço do cortiço e o perfil de seus moradores pode ser observada na Figuras 52. Ali está o bêbado caído ao chão... metáfora de uma decadência não apenas física, mas também moral. Todos os elementos de composição dos demais registros ali estão e somam-se à imagem do homem caído, embriagado e completamente dominado pelo seu vício. Decadência e impotência ante a miséria social e moral.

Mesmo a literatura se encarregava de construir imagens sobre este tipo de habitação, e talvez seja no romance $O$ Cortiço, de Aluísio Azevedo, 


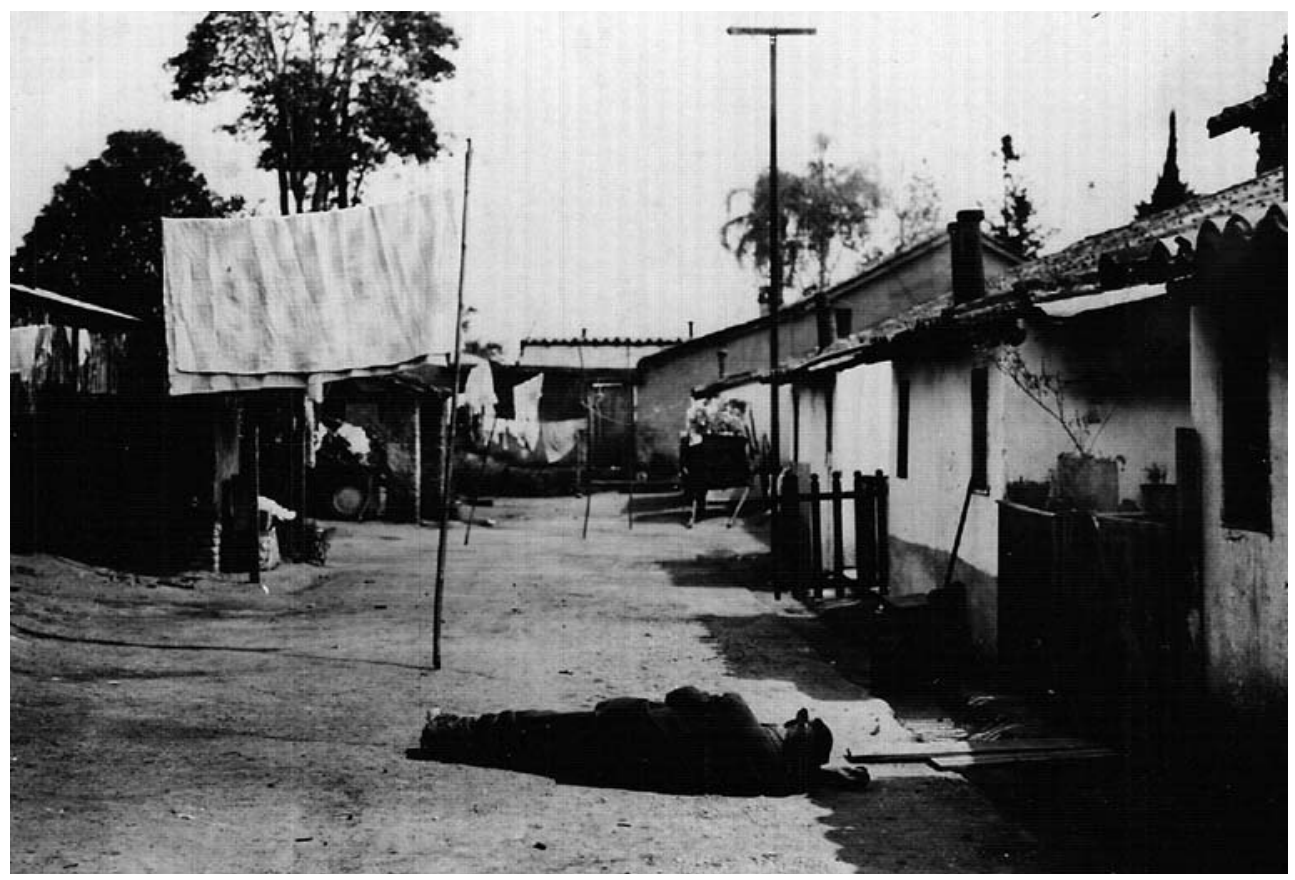

Figura 52 - Geraldo Horácio de Paula Souza. Bêbado caído ao chão em cortiço de São Paulo, 1919-1925, gelatina a partir de Kodak Graflex Auto 4"x 5" Banoh x Lomb. TESSAR, f.45. Acervo da Biblioteca Faculdade de Arquitetura e Urbanismo da USP, São Paulo. Reprodução do Laboratório da FAUUSP.

que encontramos uma descrição à altura: "naquela terra encharcada e fumegante, naquela umidade quente e lodosa, começou a minhocar, a fervilhar, a crescer, um mundo, uma coisa viva, uma geração, que parecia brotar espontânea como larvas no esterco" (AZEVEDO, 1986). O cortiço era representado como algo vivo, que pululava e reproduzia-se, onde, como vermes, seus habitantes pareciam brotar e proliferar por todas as partes.

Tanto em São Paulo como em Lisboa, o espaço do cortiço aparecia como área limítrofe dos territórios da marginalidade. Em muitos casos, seus moradores eram confundidos com os excluídos sociais que 'contaminavam' a sociedade com seus vícios e vida pouco virtuosa (Figuras 53).

Confundindo-se os territórios da pobreza, miséria e exclusão, os cortiços tornavam-se um território de solidariedades diversas e campo de forças sociais de diferentes agentes. Ali estavam os trabalhadores urbanos que ganhavam a vida apregoando e mercadejando pelas ruas da cidade e pequenos trabalhadores da indústria e do comércio. Havia também os pequenos comerciantes e aqueles, é claro, que não pertenciam a qualquer extrato produtivo, aguardavam pelo emprego nunca obtido; ou perdido, pela doença, velhice ou vício. Eram estes últimos que engrossavam os números e fileiras do exército de inativos que perambulava pelas ruas da cidade. Era também neste território de exclusão que a prostituição ganhava território e fazia suas vítimas. Vítimas eram 


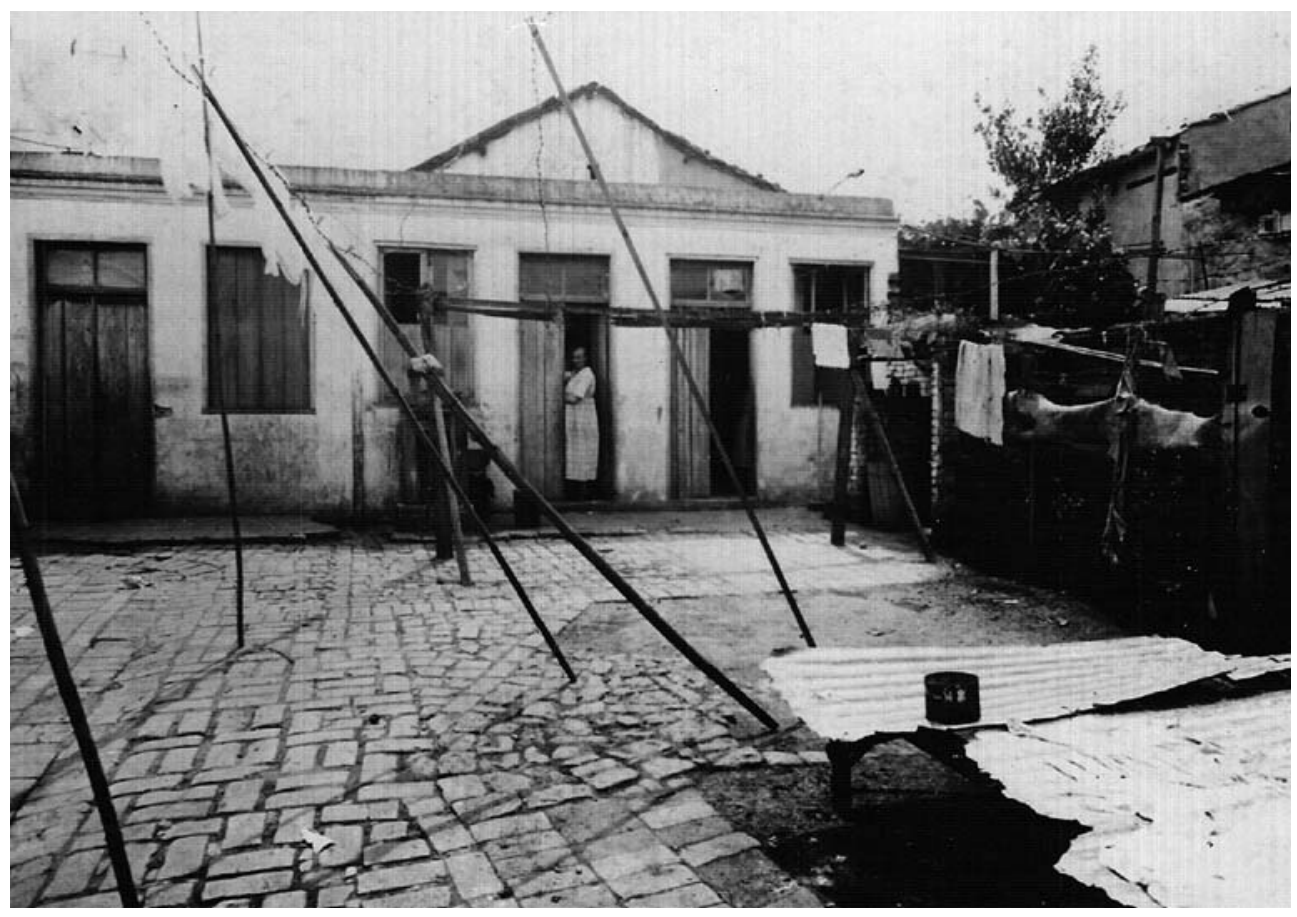

Figura 53 - Geraldo Horácio de Paula Souza. Cortiços em São Paulo, 1919-1925, gelatina a partir de Kodak Graflex Auto 4"x 5" Banoh x Lomb. TESSAR, f.45. Acervo da Biblioteca Faculdade de Arquitetura e Urbanismo da USP, São Paulo. Reprodução do Laboratório da FAUUSP.

as meretrizes que buscavam através do seu corpo o ganho para a sua sobrevivência... Vítimas eram muitos dos seus clientes, contaminados pela sífilis e outras formas de doenças contagiosas. Estudos neste sentido indicavam que a maioria dos casos de contaminação por sífilis vinha do contágio através de relações com prostitutas, chegando, ao final da década de 1920, com índices de $94 \%$.

Considerações finais

$\bigcirc$ contato com as diferentes coleções de fotografia possibilitou um alargamento da concepção que se tinha, até então, de trabalho com fontes fotográficas. A experiência de uma análise comparativa entre duas cidades, em dois continentes diferentes, tendo em comum um mesmo período levou à confirmação da tese de que o tema cidatino e os problemas de adequação de espaços e normalização de regras de conduta, convívio, abastecimento, entretenimento e disputas sociais eram constantes e estavam presentes na metropolização de espaços e de vidas. Lembre-se aqui, novamente, da produção de Eugene Atget na França, Jacob Riis e Lewis Hine nos EUA, August Sander na 
Alemanha, Allinari na Itália, e os argentinos George Asfeld, Ernesto Schilie, Cristiano Júnior, Fernando Paillet; quase todos eles fotógrafos, no princípio do século XX, e preocupados com as temáticas em torno da cidade. Todos, sem exceção, através de suas imagens, discutindo os problemas que o viver urbano trazia: a cidade era um tema constante para aqueles que produziam imagens no começo do século XX, movidos provavelmente pelo fascínio do ritmo, da velocidade e do grande número de transeuntes por suas ruas.

Benoliel não era um intelectual nem tão pouco militante social, mas, através de acurada sensibilidade, registrava os problemas com que, diariamente, tinha de se defrontar. Seu olhar era jornalístico: uma imagem tendo de valer por muitas palavras. Paula Souza, ao contrário, era médico, intelectual e político com convicções eugênicas muito arraigadas. Defendia uma sociedade limpa, livre de vícios e más condutas sociais e higiênicas. No entanto, cada um deles registrava o temor das doenças, o excesso de pessoas defendendo sua sobrevivência e a de suas famílias nos centros urbanos, o espaço informal digladiando-se com as leis de regulamentação.

Ao mesmo tempo, cada imagem revela meandros de uma tessitura rica em detalhes, que podia ser "puxada" em diferentes direções. A comunicação das imagens com as diferentes fontes ajudou a dar consistência e segurança à costura proposta. Afinal, interessava descortinar olhares, descobrir formas de ver a cidade, caminhar por suas ruas, perder-se em suas ruelas, conhecer seus habitantes através das lentes dos fotógrafos. Cada um ao seu modo, e de acordo com seu repertório, oferecia um modo de ver e de pensar a cidade. Os registros fotográficos apontaram nesta direção e representaram uma das portas de acesso a outras fontes, igualmente eloqüentes e comunicadoras desta nova forma de viver a urbanidade. A fotografia, neste sentido, representou um dos muitos olhares possíveis sobre a cidade. Através delas e do cruzamento com as diferentes fontes chegou-se a variados temas, dentre eles o sanitarismo e a regulação sanitária, abrangendo seus diferentes campos de atuação; a multidão na cidade - entendida em seus diferentes movimentos: nas trocas econômicas e simbólicas, no trânsito e tráfego de pessoas por ruas, feiras, avenidas, mercados, em greves e em diferentes formas de ajuntamento, ou mesmo na sua ociosidade despropositada por ruas, praças e becos; os sistemas de escoamento dos dejetos físicos, como os sistemas de abastecimento hídrico e sistemas de despejos como os esgotos e, finalmente, a rede de abastecimento e regulação de leis de mercado: produção, distribuição e consumo.

Encontrar um eixo que pudesse tecer as diferentes tramas desse tecido social presente em duas cidades separadas por um oceano e unidas por práticas de metropolização foi o maior de todos os desafios. Optar pelo discurso sanitário foi a saída, já que dele provinha boa parte das críticas e das intervenções no espaço urbano, como forma de normalizar e regulamentar existências citadinas.

Do jogo de imagens e da aproximação com os personagens urbanos, notou-se a formulação de regras para um crescente mercado de trabalho, onde novas e antigas profissões conviviam em uma cidade que se espalhava e que via crescer consigo diferentes necessidades. Instituía-se um mercado onde as 
relações de troca e relações sociais eram normalizadas por meio dos contratos formais, que começavam a substituir modos informais de economia. Deste universo, as greves surgiam como uma resposta às inúmeras tentativas de normalização e serviam para indicar que as "regras" para o jogo social nem sempre possuíam adeptos voluntários...

Os trabalhadores urbanos revelados através das imagens eram muitos e indicavam uma nova tendência comportamental para aqueles que viviam em cidades que se metropolizavam. Assim, por exemplo, as varinas trazidas pelas lentes de Benoliel revelavam uma forte tendência à modificação nos papéis da economia monetária, onde mulheres colocavam-se à parte de seus companheiros, independentes e igualmente circulando em diferentes funções. $\bigcirc$ papel do trabalho feminino nas ruas, tanto de São Paulo como de Lisboa, indica um predomínio de mulheres em diferentes funções e espaços urbanos, em especial nas atividades ligadas ao abastecimento. São as vendedoras de hortaliças, aves e frutas, as lavadeiras, as costureiras, as varinas que circulam pelas ruas, ou as que, nada possuindo, vendem o próprio corpo e a sorte. Andavam por todas as partes ganhando a sua sobrevivência e a de seus dependentes. Muitos desses menores que as auxiliavam em suas atividades - ou que mendigavam ao seu lado - catavam ou apregoavam seus produtos.

No universo masculino, surgem diferentes trabalhadores, que estão pelas ruas transportando água - como no caso dos galegos aguadeiros - e que, além do transporte da água, podiam ser vistos fazendo quase que um pouco de tudo: desde entregadores de bilhetes de amor até carregadores de mudanças, chamados de imperadores dos chafarizes em tempos de seca. Ou podiam ser os vendedores das rendas e outros produtos da saloia. Ou quem sabe, os carregadores de malas da Estação da Luz, em São Paulo, ou mesmo os vendedores de bilhetes de loteria e jornais, ou os trabalhadores da limpeza urbana, os engraxates, vendedores ambulantes de diversos produtos, vendedores estabelecidos de diferentes gêneros etc.

Se há um mercado que abastece, nutre e movimenta a cidade, há também uma periferia que, em muitos momentos, exclui, marginaliza e degrada. São os seus habitantes que compõem a margem da sociedade e que estão localizados nos bairros limítrofes ou na reclusão dos cárceres, hospitais e outras instituições de confinamento, onde a doença entra como mais um elemento de marginalização e de exclusão do mercado produtivo. Estes sim têm, em seu entorno, os limites colocados por grades e muros... Vivem a reclusão de forma bem marcada e definida. Mantidos nesta condição, deixam de ser preocupação da sociedade, que prefere vê-los cercados e distantes.

E através do olhar do cronista-fotógrafo é que puderam ser visitados muitos destes espaços, onde, por meio de seus clichês, foi possível tomar contato com algumas das diferentes formas de ver e interpretar seu tempo e o seu mundo. 


\section{REFERÊNCIAS}

ABEL, Marília.As profissões femininas na Lisboa Ribeirinha In: COLÓQUIO TEMÁTICO: LISBOA RIBEIRINHA, 2. 1997, Lisboa. Actas... Lisboa: Câmara Municipal de Lisboa, Departamento de Património Cultural-Divisão de Arquivos, 1997.

AZEVEDO,Aluísio. O Cortiço. São Paulo, Ática, 1986.

BASTOS, Sênia. Na Paulicéia por conta própria 1870-1886. 1996. Dissertação (Mestrado em 1996) - Faculdade de História Social Pontifícia Universidade Católica, São Paulo, 1996.

BOURDIEU, Pierre. Un art moyent: essai sur les usages sociaux de la photographie. Paris: Minuit, 1978.

BRESCIANI, Maria Stella Martins (Org.). Imagens da Cidade - séculos XIX e XX. São Paulo: ANPUH; Marco Zero; Fapesp, 1994.

BRESCIANI, Maria Stella Martins. Metrópoles: as faces do monstro urbano (as cidades no século XIX). Revista Brasileira de História, n. 8 e 9, p. 35-68, Co-edição com Editora Marco Zero, 1985.

CAMARgO, Ana Maria de Almeida; BELlOTO, Heloísa Liberalli. Dicionário de terminologia arquivística. São Paulo:Associação dos Arquivistas Brasileiros-Núcleo Regional de São Paulo; Secretaria de Estado da Cultura-Departamento de Museus e Arquivos, 1996.

CAMPOS, Cristina de. A cidade através da Higiene, 1925-1945: as propostas de Geraldo Horácio de Paula Souza para São Paulo. 2001. Dissertação (Mestrado em Arquitetura e Urbanismo) Faculdade de Arquitetura e Urbanismo, Universidade de São Paulo, 2001.

CANDIDO,Antonio (Org.) A Crônica. Campinas: Editora da Unicamp; Rio de Janeiro: Fundação Casa de Rui Barbosa, 1992.

CARVALHO, Maria Alice Rezende de. Quatro vezes cidade. Rio de Janeiro: Sette Letras, 1994.

CARVAlHO, Vânia Carneiro de; et al. Fotografia e História: ensaio bibliográfico. Anais do Museu Paulista. São Paulo, v. 2, jan.-dez. 1994 (Nova Série).

CERTEAU, Michel de. A Cultura no plural. Campinas: Papirus Editora, 1995.

. A escrita da história. Rio de Janeiro: Forense Universitária, 1990.

CHALOUB, Sidney. Cidade febril: cortiços e epidemias na corte imperial. São Paulo: Companhia das Letras, 1996.

CHARTIER, Roger (Org.). Práticas de Leitura. São Paulo: Estação Liberdade, 1996.

CORDEIRO, Graça Índias. Um bairro no coração da cidade: um estudo antropológico sobre a construção social de um bairro típico de Lisboa. 1995. Tese (Doutorado em Antropologia Social) - Instituto Superior de Ciências do Trabalho e da Empresa, Lisboa, 1995. 
DIAS, Marina Tavares. Lisboa Desaparecida.v. 1-4. Lisboa: Quimera, 1990.

DINIS, Caldeiron. Tipos e factos da Lisboa do meu tempo. 2. ${ }^{\text {a }}$ ed. Lisboa: Editorial Notícias, [s. d.].

FABRIS,Annateresa (Org.). Fotografia: usos e funções no século XIX. São Paulo: Edusp, 1991.

FOUCAULT, Michel. Microfísica do poder. Rio de Janeiro: Graal, 1979.

O nascimento da medicina social. In: Microfísica do Poder. $13 .^{\mathrm{a}}$ ed. Rio de Janeiro: Graal, 1998.

GUINOTE, Paulo Jorge Alves. Quotidianos femininos (1900-1933). v. 1-2. Lisboa: Prêmio Organização Não Governamental do Conselho Consultivo da Comissão para a Igualdade e para os Direitos da Mulher, 1997.

HILlMAN, James. Cidade E Alma. São Paulo: Nobel, 1993.

KOSSOY, Boris. A fotografia como fonte histórica. São Paulo: Museu da Indústria, Comércio e Tecnologia de São Paulo, 1980.

LE GOFF, Jacques. História e Memória. São Paulo: Editora da Unicamp, 1996.

LEITE, Míriam L. Moreira. Fotografia de família: potencialidade e limitação da documentação fotográfica. Cadernos Ceru, São Paulo, n. 18, p. 79-89, maio 1983.

A fotografia e as Ciências Humanas. BIB, Rio de Janeiro, v. 25, p. 185-246, 1988.

MUNFORD, Lewis. A cidade na bistória. São Paulo: Martins Fontes; Brasília: UnB, 1982.

PAILHOUS, Jean. La représentation de l'espace urbain. Paris, Presses Universitaire de France, 1970.

PAIS, José Machado. A prostituição e a Lisboa boémia do século XIX aos inícios do século XX. Lisboa, Editorial Querco, 1985.

PERROT, Michelle. Os excluídos da história. São Paulo: Paz e Terra, 1988.

PINTO, Luís Leite. Subsídios para a bistória do abastecimento de água na cidade de Lisboa. Lisboa: Imprensa Nacional-Casa da Moeda, 1972.

MUSEU CALOUSTE GULBENKIAN (Lisboa, Portugal). Portugal 1900: catálogo. Lisboa, 29 jun.-10 set. 2000.

REVISTA DO PATRIMÔNIO HISTÓRICO EARTÍSTICO NACIONAL: Cidades. Rio de Janeiro:IPHANMinC, n. 23, 1994.

REZENDE, Eliana Almeida de Souza. Imagens de cidade: clichês em foco... (São Paulo e Lisboa: 1900-1928). 2002.Tese (Doutorado em História Social) - Instituto de Filosofia e Ciências Humanas, Universidade Estadual de Campinas, 2002. 
RIBEIRO, Maria Alice Rosa. História sem fim... um inventário da saúde pública: São Paulo, 18801930. 1991. Tese (Doutorado em Economia) - Faculdade de Economia, Universidade Estadual de Campinas, 1991.

ROLNIK, Raquel. Cada um no seu lugar! São Paulo, início da industrialização: geografia do poder. 1981. Dissertação (Mestrado em Arquitetura) - Faculdade de Arquitetura e Urbanismo, Universidade de São Paulo, 1981 (mimeo).

História urbana: história na cidade? In: Revista. Cidade E Cidades: Modernização das cidades brasileiras nos séculos XIX e XX. Salvador: Faculdade de Arquitetura da Universidade Federal da Bahia.

RONCAYOLO, Marcel. Cidade. In: Enciclopédia Einaudi: Região. v. 8. Lisboa: Imprensa NacionalCasa da Moeda, 1985.

ROUANET, Sérgio Paulo. É a cidade que habita os homens ou são eles que moram nela? Revista USP, São Paulo, n. 15, set-nov. 1992.

SAKAGUCHI, Maria Akemi. Da medicina ao urbanismo, as origens do primado da mobilidade. 1999. Dissertação (Mestrado em Arquitetura) - Faculdade deArquitetura e Urbanismo, Universidade de São Paulo, 1999.

SANTOS, Milton. Espaço E Método. 4. ${ }^{\mathrm{a}}$ ed., São Paulo: Nobel, 1997.

SENNETT, Richard. Carne e Pedra: o corpo e a cidade na civilização ocidental. Rio de Janeiro: Record, 1997.

SONTAG, Susan. Ensaios sobre fotografia. Rio de Janeiro:Arbor, 1981.

SÜSSEKIND, Flora. Cinematógrafo das Letras. São Paulo: Companhia das Letras, 1987.

TURAZZI, Maria Inez.Poses e trejeitos: a fotografia e as exposições na era do espetáculo, 1839/1889. Rio de Janeiro: Funarte/Rocco, 1995.

VIGARELLO, Georges. O limpo e o sujo: uma história da higiene corporal. São Paulo: Martins Fontes, 1996.

WENDERS, Wim [Wilhelm]. A paisagem urbana. Revista do Patrimônio Histórico e Artístico Nacional: Cidades, Rio de Janeiro, n. 23, p. 181-189, 1994.

WILLIAMS, Raymond. Cultura e Sociedade

Artigo apresentado em 3/2006. Aprovado em 12/2006. 